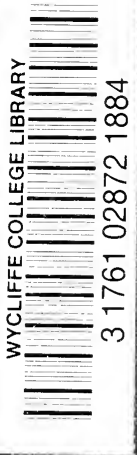




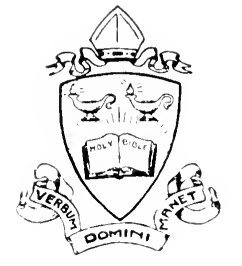

LIBRARY

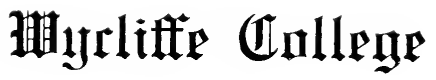

TORONTO

Sheif No. BT30I RT3

Rogister No.. 13336

Oet $27,19.22$ 




\section{THE CHRIST OF FAITH AND THE JESUS OF HISTORY}





\section{THE CHRIST OF FAITH}

AND THE

\section{JESUS OF HISTORY}

BY

D. M. ROSS, D.D.

LONDON

JAMES CLARKE \& CO., LIMITED

$13 \& 14$, FLEET STREET, E.C.4 



\section{PREFACE}

In most of the churches there are a not inconsiderable number of persons, leal-hearted in their acceptance of the lordship of Jesus, who have difficulties in regard to what they suppose to be the officially authoritative expression of the Christian faith. They have difficulties, for example, in regard to some of the ways in which convictions, involved in the confession of the lordship of Jesus, are expressed in the doctrinal creeds, and in regard to the use to which these creeds are put. They find some things in the creeds a burden for the intellect, not a liberating and gladdening power for the spirit; and these things, they feel, are somehow out of touch with the ideals of their Lord. They are conscious that their ways of thinking are considered by many of their fellow Christians as inconsistent with membership in the church, in whose fellowship they have learned to know and love their Lord. They are at heart attached to the Christian Society with its great traditions, with its manifold helpful influences for fostering Christian life and character, 


\section{Preface}

and with its immense opportunities for rendering the highest kind of service to their day and generation. But, too often, under the pressure of their perplexity, their enthusiasm for the Christian Society wanes, and their effective service to its well-being slackens. Their loyalty to Jesus as Lord is not shaken ; it is, partly, at least, loyalty to the Jesus of the Gospels which has brought them to what they recognise to be an unhappy situation.

An additional perplexity may to some extent trouble them. It is alleged in some quarters that if we go "back to Christ" it may be found that the Jesus of history will not justify the convictions, that Jesus is not merely a great religious teacher, but the Redeemer and Leader of humanity; that the God with whom Christians have to do, and whom they worship is God revealed in Jesus; that a devotion is due to Jesus other than that which can be paid to the greatest religious teacher. If this were true, the cry "Back to Christ" would bring up these perplexed individuals in uncongenial latitudes. The Christ, who is at the heart of the confession: Jesus is Lord, would then be not the Jesus of history, but the creation of the followers of Jesus from the apostolic age onwards. Such a conclusion, were it demanded by the historical 


\section{Preface}

facts, as we think it is not, would mean that the lordship of Jesus would be robbed of its deepest significance, and devotion to Jesus would be reduced to reverence for one who is on the same plane with other great religious teachers.

It is in view of such difficulties and perplexities that this volume has been written, and with the hope that such an answer will be given to some of the questions which have been raised as will help to strengthen loyalty to Jesus, "the Lord of all good life," and to the Christian Society through which the spirit of Christ works for the realisation of the divine purpose with the human family.

The subject-the relation of the Jesus of history to the Christ of faith-with one aspect of which this volume deals, may well have a special interest to-day for the churches as well as for individuals. They are all eager to discover how they may minister more successfully to the needs of a sorely distracted world. Each branch of the Christian Society is disposed to believe that some of the other branches have in some measure departed from the ideals of Jesus. May it not be the wisdom of each branch to be willing to re-examine some of its accepted ideals in the light of that standard? Might not such a 


\section{Preface}

re-examination be helpful for the discovery of better methods of appeal for loyalty to Jesus as Lord? And if such a re-examination issued in increased loyalty to the ideals of the one Lord, might not churches, at present separated from each other, find here the most hopeful line of approach towards the expression of their unity of spirit in increased unity of organisation? 


\section{CONTENTS}

\section{REGNANT IDEALS OF JESUS}

I The Sovereignty of Goodness

II The Fatherhood of God and the Sonship of Man

III The Kingdom of God and the Leader in the KingDOM

IV The Son of God

V How Jesus Interprets His Death

\section{IN THE APOSTOLIC AGE}

VI The Abiding Presence of Jesus

VII The Lordship of Jesus

VIII The Moral Heat of the Earliest Christians

IX God in Christ

80

$X$ The Fellowship of the Disciples of Jesus

\section{IN THE SUBSEQUENT CENTURIES}

XI The Fact and Legitimacy of Development

XII Loyalty to the Ideals of Jesus a Test of Legitimate Development 


\section{Contents}

CHAPTER

PAGE

XIII Devotion to Jesus

XIV Emphasis on Goodness of Life

XV God Conceived and Worshipped as God in Christ 152 XVI The Fellowship and Unity of the Christian SocIETY

XVII Sacramentarianism : Lowering the Conception of the Grace of God in Christ

XVIII Sacerdotalism : Narrowing the Access to God in Christ

XIX Orthodoxy: Magnifying Assent to Theological Doctrines about Christ over Loyalty to Christ in Heart and Life

XX Epilogue 
THE JESUS OF HISTORY 

Regnant Ideals of Jesus 
THis section deals with the regnant ideals of Jesus which have a direct or indirect bearing on these two points : (I) whether certain tendencies in the development of Christian doctrine, worship and ministry run counter to the ideals of Jesus ; (2) whether the ideals of the historical Jesus will bear the weight of the Christ enshrined in the faith and worship of Christendom.

The investigation of these ideals-not in stray texts, but in the whole story of His personality and teaching-while it demands appreciation of spiritual values, is a work for historical science, untrammelled by the dogmatic theories either of theologians or of those who claim to be the defenders of a rigorous scientific method.

For reasons which will be obvious to those who are familiar with the present state of New Testament scholarship our investigation in the following chapters will be based mainly on the first three Gospels. 


\section{CHAPTER I}

\section{The Sovereignty of Goodness}

$T_{H E}$ collection of the sayings of Jesus, which is known as the Sermon on the Mount, is recognised as setting forth fundamental aspects of His message. A main theme-we might almost say the chief theme-of that collection is the sovereignty of goodness. "Blessed are they that hunger and thirst after righteousness" (Matt. v. 6); "Seek ye first his kingdom and his righteousness" (Matt. vi. 33) - these words strike the keynote of the greater part of the teaching of the Sermon on the Mount. Goodness is at the foundation of a true life. "Everyone therefore which heareth these words of mine, and doeth them, shall be likened unto a wise man, which built his house upon the rock" (Matt. vii. 24). No profession of reverence for the person of Jesus makes up for the lack of goodness. "Not every one that saith unto me, Lord, Lord, shall enter into the kingdom of heaven, but he that doeth the will of my Father which is in heaven "(Matt. vii. 2I). 


\section{The Jesus of History}

This outstanding feature of the Sermon on the Mount is characteristic of the whole teaching of Jesus; it is integral to His teaching about God, about the Kingdom of God, about loyalty to Himself. According to Jesus, goodness is the thing of absolute worth. It is on this the eternal issues of life hang.

The goodness which Jesus demands is something other than merely correct moral conduct; it is goodness which wells up from an inward spring. So He insists upon going behind the outward action to the motive which prompts it. There can be no true goodness in the absence of a good heart. "Do men gather grapes of thorns or figs of thistles? . . . A good tree cannot bring forth evil fruit, neither can a corrupt tree bring forth good fruit" (Matt. vii. I6, I8). "Out of the abundance of the heart the mouth speaketh. The good man out of his good treasure bringeth forth good things: and the evil man out of his evil treasure bringeth forth evil things" (Matt. xii. 34, 35).

The significance of $\mathrm{His}$ interpretation of the sovereignty of goodness is illumined by His controversies with the Pharisees. In their teaching the Pharisees did not ignore goodness, but they tended to put it on the same level with a multiplicity of ritual observances: with the result that it no longer stood out as the thing of absolute worth. It is this obscuring of the sovereign place of goodness 


\section{The Sovereignty of Goodness}

in the religious life which constitutes the gravamen of the charge which Jesus brings against the Pharisees: "Woe unto you, Scribes and Pharisees, hypocrites, for ye tithe mint and anise and cummin, and have left undone the weightier matters of the law, judgment, and mercy, and faith" (Matt. xxiii. 23). "Go ye and learn what this meaneth, I desire mercy, and not sacrifice" (Matt. ix. I3). The question in dispute between Jesus and the Pharisees was this: What place in the religious life is to be assigned to goodness?

In the teaching of Jesus there are lessons on the homely goodness which is inculcated by every worthy ethical teacher, Jew or Gentile-lessons, for example, on the duty children owe to their parents (Mark vii. II), on charitable judgment of others (Matt. vii. I, 3), on truthfulness of speech (Matt. v. 34, 37), on neighbourly kindness (Matt. $\mathrm{xxv} \cdot 3 \mathrm{I}-46)$.

But it is elsewhere we have to look for His characteristic teaching. He passes beyond accepted standards. Beyond the standard of the religious circles of His day: "Except your righteousness shall exceed the righteousness of the scribes and Pharisees, ye shall in no wise enter into the kingdom of heaven" (Matt. v. 20). Beyond the standard of the sacred Scriptures: "Ye have heard that it was said to them - . . but I say unto you" (Matt. v. 2I, 22). And, of course, beyond the 


\section{The Jesus of History}

conventional standard of social duty: "If ye love them that love you, what reward have ye ? do not even the publicans the same? And if ye salute your brethren only, what do ye more than others ?" (Matt. v. 46, 47).

In demanding from His followers that they "do more than others" $\mathrm{He}$ calls for a new interpretation of ambition. He does not discourage eagerness to put one's powers into the fullest possible exercise, and thereby to achieve greatness. But $\mathrm{He}$ is pre-occupied with the thought of what one may do for his fellows, and this thought colours His interpretation of greatness, and of the ambition to be great. So He finds the path to greatness, not in forging ahead to achieve a selfish success, but in turning powers and opportunities to account in the service of others. After the request of the sons of Zebedee for first places in the Kingdom of God has stirred ill-feeling in the other ten, $\mathrm{He}$ calls the twelve to Him and says: "Ye know that they which are accounted to rule over the Gentiles lord it over them. But it is not so among you : but whosoever would be great among you, shall be your minister : and whosoever would be first among you shall be servant of all. For verily the Son of Man came not to be ministered unto, but to minister, and to give his life a ransom for many" (Mark x. 35-45).

Jesus calls also for a transvaluation of riches. The people in Palestine to whom Jesus spoke looked 


\section{The Sovereignty of Goodness}

upon riches probably very much as we moderns do. To regard the possession or acquisition of money as the main thing in life, to gain money by dishonourable methods, or to spend it in unworthy ways-all that, of course, was condemned by public opinion. But the love of money and of the things which money could buy, even when it involved no violation of recognised moral standards, was often strong enough to smooth the way for the growth of selfish arrogant tempers, and to block the way for the growth of spiritual character. The love of money was often at odds with the love of man and the love of God.

It is from this point of view we are to look at the revolutionary teaching of Jesus about riches. He is not expounding the function of wealth in economic life. What $\mathrm{He}$ is concerned with is the danger to man's highest life, which is involved in the prevalent estimate of the worth of riches and in the prevalent devotion to the pursuit of riches. "Take heed, and keep yourselves from all covetousness: for a man's life consisteth not in the abundance of the things which he possesseth" (Luke xii. I 5). He conceives man as contended for by two antagonistic ideals of the chief good-the ideal of money and what money can buy, and the ideal of the Kingdom of God and what the Kingdom means in spiritual life and character. "No man can serve two masters, - . ye cannot serve God and Mammon" 


\section{The Jesus of History}

(Matt. vi. 24). Mammon is an enemy to be feared and watched. "How hardly shall they that have riches enter into the Kingdom of God! For it is easier for a camel to enter in through a needle's eye than for a rich man to enter into the Kingdom of God" (Luke xviii. 24, 25). Mammon is the enemy of the rich young ruler. The youth may have been blameless in his moral conduct, but Jesus sees that his way to the higher life, to which he is aspiring, is blocked by devotion to his great possessions, and tells him how his way can be opened up : "One thing thou lackest: go, sell whatsoever thou hast and give to the poor : and come, follow me" (Mark x. 2I). Without a revolution in his attitude to riches his quest of the higher life is hopeless. "How hard is it for them that trust in riches to enter into the Kingdom of God" (Mark x. 24).

The most distinctive feature of the teaching of Jesus upon the good life is to be found in His lessons on the forgiveness of wrongs and the renunciation of rights. It is this feature of His teaching which has impressed a modern representative of liberal Judaism. "To keep even ordinary life sweet and clean, to prevent every-day morality becoming commonplace, and commonplace morality degenerating into Philistinism, we need, besides and beyond the more equable, balanced and sensible type of teaching, that provocative, paradoxical and heroic 


\section{The Sovereignty of Goodness}

type, which is characteristic of the Gospels and of Jesus." I Tolstoi tells us that it was by this feature of the teaching of Jesus he was specially drawn to Christianity. "From the time when almost in childhood I began to read the Gospel for myself, what touched and affected me most in it were those passages in which Christ preached of love, humility, self-abasement, self-sacrifice, and the repayment of evil by good. This has always been for me the substance of Christianity, that which my heart loved in it." ${ }^{2}$

In His teaching on the forgiveness of wrongs and the renunciation of rights, Jesus is not laying down statutory rules for the organisation of social life, He is setting forth ideals which can only be responded to where the impulse of the "good heart" is at work. It is on this impulse $\mathrm{He}$ lays the accent. "Love your enemies, do good to them that hate you, bless them that curse you, pray for them that despitefully use you" (Luke vi. 27, 28). When He says : "Resist not evil (or, him that is evil); but whosoever smiteth thee on thy right cheek, turn to him the other also. And if any man would go to law with thee, and take away thy coat, let him have thy cloke also" (Matt. v. 39, 40), what He is concerned with is not the mere outward act, but that inward freedom from pre-occupation with one's

I Montefinre, The Religious Teacbing of Fesur, p. 78 .

2 Cbrist's Cbristianity, p. ror. 


\section{The Jesus of History}

rights, which is secured by the loving heart, under whose constraint sensitiveness to one's rights is overcome by devotion to a wider good-nobler life for oneself and for the offender.

The teaching of Jesus about non-resistance and forgiveness of wrongs, as well as about riches, is, it is said, unworkable. We cannot avoid caring for money, so it is urged, unless we betake ourselves to the hermit's cell in the desert; if we allow every wrongdoer to go unchecked and unpunished, the result will be the triumph of the forces of evil and the disintegration of social order; if we lightly pass over every invasion of our rights, we shall be doing a questionable service to the aggressor and to society. All that and much more may be true, but the teaching of Jesus, construed not as rules of conduct, but as ideals swaying the inward temper, appeals to what is highest in man, and response to it has a direct, if not always an obvious bearing upon the social, and even upon the economic order whose stability this teaching is supposed to imperil.

The ideals of heroic goodness which Jesus keeps before His followers, make it plain that He expects them to " do more than others." It is precisely here that many persons find the attractiveness of His ethical teaching. They are impatient with goodness which does not rise above the conventional social code; they long for something more heroic, 


\section{The Sovereignty of Goodness}

for what " exceeds duty and outstrips requirement." The teaching of Jesus appeals to this temper; it opens up a new world, where there is scope for moral genius. If $\mathrm{He}$ demands what seems impossible, that only wins over the heroic temper: it is the impossible which is the lure for the saint and the hero. Under the power of His ideals the individual is stimulated to enlarge the realm of the possible. And here is one secret of moral progress in a society. "If things are ever to move upward, some one must be ready to take the first step, and assume the risk of it. No one who is not willing to try charity, to try non-resistance as the saint is always willing, can tell whether these methods will or will not succeed.

- . These saintly methods are creative agencies.

- . This practical proof that worldly wisdom may be safely transcended is the saint's magic gift to mankind."

× James, The Varicties of Religious Experience, p. 358. 


\section{CHAPTER II}

\section{The Fatherhood of God and the Sonship of Man}

Jesus takes for granted that there can be no true goodness apart from God. Goodness and God are indissolubly united. God is the ethical ideal: "Ye therefore shall be perfect as your heavenly Father is perfect" (Matt. v. 48). It is the magisterial authority of God which finds expression in the imperiousness of the categorical imperative of duty. Loyalty to God is loyalty to goodness. It is by goodness, which is the doing of the will of God, that God is served. Love to God and love to man are closely linked together: "Thou shalt love the Lord thy God . . . Thou shalt love thy neighbour as thyself " (Mark xii. 30, 3I).

Thus there can be no divorce between religion and morality, between God and goodness. Where God is conceived as merely the necessary postulate for such an understanding of the world as shall be satisfactory to the intellect; or as merely the Infinite, in whom man finds refuge from the transitoriness and unsatisfyingness of all that is finite; 


\section{Fatherhood of God and Sonship of Man}

or as an omnipotent Lawgiver and Judge (a "Sultan in the sky") who imposes laws upon man in the arbitrary exercise of His sovereign power, there may well be the possibility of religion and morality representing rival interests. But if God is conceived, as by Jesus, to be the God of conscience, to be the ideal and inspirer of goodness, that possibility is ruled out. God and goodness represent one common interest.

The teaching of Jesus about God bears in a wondrously emancipating way upon the quest of a speculative understanding of the life of man, and of the great world, but nowhere does He give any hint of the need of a "proof" of the existence of God. What $\mathrm{He}$ is concerned with is not a God who needs to be proved, but God who is experienced in the sphere of conscience; to whom witness is borne by "the light that is in thee" (Matt. vi. 23). So it is upon the heart and will of God towards His children, not upon speculations about the mysteries of Godhead in itself, that He concentrates attention.

The experience of God is the central reality in Jesus' own life. " The Divine presence, the union with the Father, is about Him always, like the light and air, ambient, invisible, yet incapable, even in thought, of being away." It is His experience of God, which is the secret of His teaching about God.

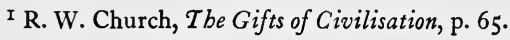




\section{The Jesus of History}

To give expression to what God means to Him, He makes use of the name Father. This name throws into relief the love of God, who "maketh his sun to rise on the evil and the good and sendeth rain on the just and unjust" (Matt. v. 45). To whatever heights the love of an earthly father may rise, all that and more is the love of God. "If ye, then, being evil, know how to give good gifts unto your children, how much more shall your Father which is in heaven give good things to them that ask him ?" (Matt. vii. I I). God has a fatherly interest in the things about which His children are concerned. "Your heavenly Father knoweth that ye have need of all these things" (Matt. vi. 32). $\mathrm{He}$ takes upon His fatherly heart the misery and heartaches of His wayward children, and cannot rest till they return to the Father's home. (Luke xv. II-32). There is no limit to His forgiving love; it is love to the uttermost. "Love your enemies that ye may be sons of your Fatber which is in beaven" (Matt. v. 44-45).

The name Father throws also into relief the intimacy of God's relations with His children. $\mathrm{He}$ is no far off Lawgiver and Judge. He is present in the sanctuary of the heart- " closer than breathing, nearer than hands and feet." $\mathrm{He}$ is the Divine Companion, backing up His children with all the resources of His gracious fellowship, strengthening them for the moral struggle, 


\section{Fatherhood of God and Sonship of Man}

heartening them in the hour of darkness and despair. $\mathrm{He}$ is all and more than all that the best father can be to his child.

The Fatherhood of God carries with it the sonship of man. The phrase used by Jesus, "that ye may be sons of God" (Matt. v. 45 ; v. 9) suggests that sonship, filial fellowship with the ever-present, ever-loving, ever-helpful Divine Companion, is what gives life its true meaning and worth. The experience of the encompassing, upholding fatherly love of God is the secret of a trustful and courageous temper ; it whispers the message of good cheer, "Be not anxious for your life," " Fear not." And the filial attitude to God means a great end to live for. To identify ourselves in filial loyalty with the ideals of our Father in heaven, to be fellow workers with $\mathrm{Him}$ in carrying out His loving purposes with His children, to seek first His Kingdom-that is an end which appeals to the noblest aspirations of the heart of man.

Jesus knows the worth and blessedness of filial fellowship with $\mathrm{His}$ Father in heaven, and $\mathrm{He}$ knows the plight of His fellows, who are strangers to this secret of true life. The language in which He speaks of their plight reveals the intensity of His pity for them. They are "sick" souls in need of a physician. They are "dead": "leave the 


\section{The Jesus of History}

dead to bury their own dead" (Matt. viii. 22). They are " in darkness": " if the light that is in thee be darkness how great is the darkness!" (Matt. vi. 23). They are "lost"; lost as forwandered sheep (Luke xv. 4); lost to the true uses of manhood (Luke xv. 8); lost as voluntary exiles from the father's home (Luke xv. II). So $\mathrm{He}$ discloses in the synagogue of Nazareth the inevitableness of His vocation " to seek and to save" : "And he opened the book, and found the place where it was written, The Spirit of the Lord is upon me, because he anointed me to preach good tidings to the poor : he hath sent me to proclaim release to the captives, and recovering of sight to the blind, to set at liberty them that are bruised, to proclaim the acceptable year of the Lord

And he began to say unto them, To-day hath this scripture been fulfilled in your ears" (Luke iv. 17-21).

At the bidding of a mighty love He takes upon His own heart the miserable plight of His fellows. $\mathrm{He}$ is mastered by a passionate longing that they may share in the blessedness of His own life of filial fellowship with His Father in heaven. $\mathrm{He}$ believes in their infinite worth, in their capacity for God and goodness. So He approaches the lost children not only with a great pity but with a reverence which amazes them.

Under the influence of His personality the 28 


\section{Fatherhood of God and Sonship of Man}

"lost" son becomes aware of his loss as never before; he has a new vision of the worth of goodness, and a new sense of his disloyalty to goodness and God; he is fain to cry: "God be merciful to me a sinner." The faith of Jesus in what he may yet be awakens a new hope; it quickens and strengthens any aspiration after loyalty to God and goodness he has ever had. His better self-his hitherto buried self-is reached and won, as with Zacchæus, who, under the power of Jesus' faith in him and His love for him, escaped from the thraldom of his worse self, and responded to the claim of his better self : "Behold, Lord, the half of my goods I give to the poor ; and if I have wrongfolly exacted aught of any man, I restore fourfold" (Luke xix. 8).

It is significant that even one who is outside the Christian faith, a gifted and open-minded Jewish scholar, has singled out the redeeming activity of Jesus as an impressive and original feature in His career; "To seek out the sinner, and, instead of avoiding the bad companion, to choose him as your friend in order to work out his moral redemption, this was, I fancy, something new in the religious history of Israel. . . . It inaugurated a new idea: the idea of redemption, the idea of giving a fresh object of love and interest to the sinner, and so freeing him from his sin. The rescue and deliverance of the sinner through pity 


\section{The Jesus of History}

and service-the work and method seem both alike due to the teacher of Nazareth."

Jesus is a religious teacher, and $\mathrm{He}$ is a religious reformer, but above all, and giving its meaning to all else, $\mathrm{He}$ is a Saviour. " $\mathrm{He}$ came to seek and to save that which was lost" (Luke xix. I0). The salvation Jesus brings involves a transformation of the individual soul at the core of his being, and the means by which this transformation is brought about is the redeeming power of His own personality. His gift is life, and it is through His own life that life is quickened.

I Montefiore, Tbe Religious Teacbing of Fesus, pp. 57, 58 . 


\section{CHAPTER III}

\section{The Kingdom of God and the Leader in the Kingdom}

THus far what we have had chiefly under consideration is the interest of Jesus in the individual and his relation to goodness and God. But His conception of goodness as the outcome of a great love and His conception of God as the Father of His children carry us beyond the narrow bounds of the individual, and of his individual interests, however worthily these may be interpreted. He deals with individuals in the sanctuary of their own souls, but $\mathrm{He}$ meets them there that He may equip them for the spacious life of a brotherhood. These two poles in His teaching, far from being opposed, are necessary to each other. There can be no worthy life for the individual apart from the society, as there can be no worthy society apart from the worthy life of its individual members.

Jesus has a great vision of what this social life is to be, in which the individual can truly find himself. In speaking of it as the Kingdom of God, He makes use of phraseology which was familiar to 


\section{The Jesus of History}

the people whom $\mathrm{He}$ addressed. The people of Israel, to whom the righteous will of God was the supreme reality, were marked out from other peoples by the loftiness and persistence of their hope of coming good. Deepseated in the heart of the better part of the people was the conviction that God had a great purpose to carry out with the national life, and that He could not fail to usher in a brighter day for their sorely tried nation. There was no uniformity in the picture of the brighter future which was sketched by the prophets or, in later times, by the writers of such apocalypses (unveilings of the future) as the Book of Enoch and the Psalms of Solomon. The pictures varied with the varying of the national fortunes and with the spiritual and intellectual gifts of the individual writers.

Jesus served Himself heir to the hope, cherished by the Jewish people, of the advent of the Kingdom of God. But His vision of the purpose of God towards His children was at once simpler and grander than that of any prophet or apocalyptist. His interpretation of what the Kingdom means is His own. He does not accept any one, not even the worthiest, of the different interpretations of the new and better day, which His hearers are disposed to espouse. His unique vision of the Kingdom of God is the outcome of His unique fellowship with God, the ideal and inspirer of heroic goodness. So $\mathrm{He}$ can say to hearers who are interested in 


\section{Kingdom of God and Leader in Kingdom}

the time of the coming of the Kingdom and in the outward forms it will assume: "The Kingdom of God is within you" (Luke xvii. 2I). However great-and it is very great-may be His hope of what the future has in store, $\mathrm{He}$ recognises that the new and better day has already come, wherever the spiritual temper of men is attuned to His own. So, too, the Kingdom of God, as interpreted by Jesus, is wide as the whole family of God's children. In His conception of the good life and of the Fatherhood of God and the sonship of man there is nothing particularistic. The Kingdom of God is universal as the heart and conscience of humanity.

Bound up with the original interpretation which Jesus gives of the Kingdom of God is His conviction that God has called Him to be the Leader in the Kingdom. When we consider the grandeur of His vision of the Kingdom of God, we may well wonder how the conviction of so unique a vocation took shape in the years preceding His baptism. We may wonder, but we cannot tell. The secret is hid in His wonderful personality.

$\mathrm{He}$ is aware from the outset of His ministry that His vocation to be Leader in the Kingdom is a heavy responsibility, and the weight of that responsibility grows ever heavier till in His hour of agony in the Garden of Gethsemane He prays: " $\mathrm{O}$ my Father, if it be possible, let this cup pass away 


\section{The Jesus of History}

from me" (Matt. xxvi. 39). But the greatness of His love inspires Him to take upon Himself the heavy burden, and to take it with a stern joy. $\mathrm{He}$ has identified Himself with His fellows. He has made His own their miserable plight, and for love's sake $\mathrm{He}$ will bear it to the uttermost, that $\mathrm{He}$ may be their Saviour.

As Leader in the Kingdom of God He brings to His God-given life-work the virility, the purposefulness, the tenacity of an indomitable will. He can be no quietist, who retires into the sanctuary of his own soul, and cares only for his own individual life of fellowship with God. He is a protagonist for God and man in the great enterprise by the vision of which His whole being is captured. It is not flight from the world which His vocation demands, but a heroic, never-ending struggle on behalf of the Kingdom of God.

\footnotetext{
This is the authentic sign and seal

Of Godship, that it ever waxes glad, And more glad, until gladness blossoms, bursts

Into a rage, to suffer for mankind And recommence at sorrow. ${ }^{x}$
}

It is in the conviction of His vocation to be the Leader in the Kingdom of God that we find the explanation of the imperious claims Jesus makes upon His followers. $\mathrm{He}$ is not a legislator laying

I Browning, Balaustion's Adventure. 


\section{Kingdom of God and Leader in Kingdom}

down such rules of conduct as are indispensable for a tolerable individual life and for a tolerable social order. $\mathrm{He}$ is Leader in an enterprise which involves the highest ethical ideal and the highest religious ideal, the richest personal life and the widest, closest brotherhood, and as such, He cannot but demand "the utmost for the highest." For here nothing can be achieved without a heroic temper, without readiness, if the need arises, for uncalculating abandonment of narrow selfish interests.

$\mathrm{He}$ is at pains to give to those who would be His followers warning as to the difficulties which the enterprise may involve. "Which of you, desiring to build a tower, doth not first sit down and count the cost, whether he hath wherewith to complete it ? Lest haply, when he hath laid a foundation, and is not able to finish, all that behold begin to mock him, saying, This man began to build and was not able to finish" (Luke xiv. 27-30). A still plainer warning is given: "Think not that I came to send peace on the earth : I came not to send peace, but a sword. For I came to set a man at variance against his father, and the daughter against her mother, and the daughter-in-law against her mother-in-law : and a man's foes shall be they of his own household" (Matt. x. 34-36). Such warnings are summed up in a terse saying attributed to Jesus 


\section{The Jesus of History}

by Origen, but not preserved in our Gospels : “ $\mathrm{He}$ that is near me is near the fire."

Many and strong are the forces that war against the Kingdom of God. There are enemies within the gate, such as " the cares and riches and pleasures of this life," and enemies without, such as entrenched interests and public opinion. For His followers Jesus needs men with the loins girt and the lamp lit, who are resolved to see the enterprise through, whatever may be the cost. "No man, having put his hand to the plough, and looking back, is fit for the Kingdom of God." Renunciation " beyond the sane limits of human nature" are called for. "If thine eye cause thee to stumble, cast it out: it is good for thee to enter into the Kingdom of God with one eye, rather than having two eyes to be cast into Gehenna" (Mark ix. 47). "Whosoever would save his life shall lose it; and whosoever shall lose his life for my sake and the gospel's shall save it" (Mark viii. 35).

It is as Leader, in whom all that the Kingdom of God stands for is focussed, that Jesus makes His claim for an extraordinary loyalty to Himself. "He makes a demand, which is beyond all others difficult to satisfy; He asks for that which a philosopher may often seek in vain at the hands of his friends, or a father of his children, or a bride of her

I Renan, Vie de Fésus, p. 312. “That moral and religious ideals, seriously taken, involved certain refusals and renunciations of freedom, Renan seemed at last entirely to forget."-Letters of William Fames, II, p. 323. 


\section{Kingdom of God and Leader in Kingdom}

spouse, or a man of his brother. He asks for the human heart ; He will have it entirely to Himself." It is an extraordinary demand which $\mathrm{He}$ makes in these words: "If any man would come after me, let him deny himself, and take up his cross, and follow me" (Mark viii. 37). "He that loveth father or mother more than me is not worthy of me: and he that loveth son or daughter more than me is not worthy of me" (Matt. x. 37). But it is just from such sayings that we learn how incomparable in His estimation is the worth of the Kingdom in which $\mathrm{He}$ is Leader, and how inseparable is the personality of the Leader from the interests of the Kingdom.

In all His demands for renunciation Jesus presupposes sensitiveness to the worth of the end for which the renunciation is to be made. $\mathrm{He}$ is no ascetic, who values self-sacrifice for its own sake. He draws naturally to " the joyous and lovely" side of life; He is gladdened by the beauty of the lilies of the field, and is cheered by the sight of boys and girls at play. He asks for no sacrifice of life's joy, except for a worthy end. And even such a sacrifice seems to Him to hold the secret of a deeper joy. "The kingdom of heaven is like unto a treasure hidden in the field; which a man found and hid; and in bis joy he goeth and selleth all that he hath, and buyeth that field" (Matt. xiii. 44). "Rejoice

\footnotetext{
I Words said, perhaps without sufficient warrant, to have been uttered by Napole on at St. Helena.
} 


\section{The Jesus of History}

and be exceeding glad, . . . for so persecuted they the prophets which were before you " (Matt. v. I2). Those who throw themselves with heart and strength into a heroic enterprise may keep close company with sorrow, but "with sorrow which is not sorrow but delight." Such joy, so Jesus suggests, will not fail loyal citizens of the Kingdom of God "who prefer it to all other things; who are proud to suffer for it; who can bear anything, so that it goes forward."

There is another aspect of the leadership of Jesus which calls for notice. As Leader He has need of followers in His enterprise. "The harvest truly is plenteous, but the labourers are few. Pray ye therefore the Lord of the harvest, that he send forth labourers into his harvest" (Matt. ix. 37, 38). To train followers to be fellow-workers, He chooses the twelve disciples " that they might be with him " (Mark iii. I4) in a specially close companionship. The training of these Twelve is an all-important part of His ministry. What He chiefly aims at in their training is to make them sharers in His own lifein His filial trust in the Father in heaven, in His ideal of the good life, in His vision of the Kingdom of God. And how can $\mathrm{He}$ bring them to be sharers in this life of His? Only through personal fellowship with Himself. Were His chief concern their

I R. W. Church, Tbe Gifts of Civilisation, p. 54. 


\section{Kingdom of God and Leader in Kingdom}

acceptance of His ethical and religious teaching, or their co-operation in developing a new religious institution, such personal fellowship might not be indispensable. But if His gift is life-His own lifehow can this be communicated save from heart to heart in the intimacies of personal fellowship ?

Through devotion to the one Master each of the Twelve was knit to the others by a bond which laid hold of them in the central depths of their being. And their deepened fellowship with one another had its issue in strengthened loyalty to the Kingdom of God and its Leader. Not as solitary, selfcentred disciples, but as comrades, infecting each the other with his devotion and courage, did they come to their understanding of the mind of Jesus and to their baptism with His spirit.

Thus discipleship with the Master carried with it the fellowship of individual disciples with one another. The Christian Society with its brotherhood and comradeship was inevitable. In this sense it is true that " to organise a society, and to bind the members of it together by the closest ties were the business of His life." But what we are told of His companionship with the Twelve does not suggest that $\mathrm{He}$ regarded it as " the business of His life" to give detailed instructions about the organisation of the society which was the inevitable outcome of His ministry. Scarcely any such instructions are

\section{Ecce Homo, ch. 9.}




\section{The Jesus of History}

to be found in the reminiscences of the disciples recorded by the evangelists. What is prominent there is the kind of life and enterprise to which $\mathrm{He}$ calls His disciples, and the emphasis on personal loyalty to the Master. $\mathrm{He}$ has, indeed, a great vision of what the society of His disciples may accomplish for the Kingdom of God, but, as to their equipment for the fulfilment of their Godgiven task, what He throws into relief is not methods of organisation, but the personal influence of disciples inspired by His own spirit. "Ye are the salt of the earth : but if the salt has lost its savour, wherewith shall it be salted ? . . . Ye are the light of the world. . . . Let your light shine before men, that they may see your good works" (Matt. v. I3-16). "The kingdom of heaven is like unto leaven, which a woman took, and hid in three measures of meal, till it was all leavened" (Matt. xiii. 33). 


\section{CHAPTER IV}

\section{The Son of God}

In the preceding chapters we have had under consideration features of the life and teaching of Jesus which suggest the question put by the disciples to one another: "Who then is this ?" (Mark iv. 4I).

As an ethical teacher $\mathrm{He}$ speaks with the authority of one who feels himself justified in setting forth higher ideals than have hitherto been recognised. He has a profound reverence for the sacred scriptures of His people, but He dares to transcend them, and to transcend them deliberately, as if it belonged to Him to utter the final word on what men owe to one another. "Ye have heard that it was said, An eye for an eye, and a tooth for a tooth: but I say unto you, Resist not him that is evil (Matt. v. 38 , 39). That formula, "But I say unto you," indicates a singular consciousness of His authority in the ethical sphere.

A singular consciousness of His significance for the realisation of the divine purpose with humanity is revealed in His conviction that $\mathrm{He}$ has been called to be Leader in that Kingdom of God, to which, in the light of His own spiritual experience, a higher 


\section{The Jesus of History}

meaning is given than ever before. Leadership in a movement, which is the goal of the whole history of Israel and the beginning of a new and grander world-order, means a unique position in human history.

Singular, too, is His claim for personal loyalty. He demands that nothing come between a man and whole-hearted devotion to Himself. It is true that the devotion to Himself $\mathrm{He}$ demands is devotion to what He stands for. But this does not lessen the singular loftiness of $\mathrm{His}$ demand. If $\mathrm{He}$ regards loyalty to Himself as loyalty to God and righteousness, the significance of His demand is but heightened.

Another singular feature in $\mathrm{His}$ life is $\mathrm{His}$ spiritual loneliness-not the loneliness of a religious ascetic or a high-minded Stoic, but of one who loves to be in the company of His fellows, and to share their joys and sorrows. Those with whom $\mathrm{He}$ is in closest touch are often unable to sympathise with His thoughts and aims. Members of His family say of Him : "He is beside himself" (Mark iii. 21). The Twelve prove themselves even to the end to be " slow of understanding." Turn where He may, He often fails to find the understanding and sympathy for which $\mathrm{He}$ craves. On the deepest levels of His experience He has to dwell apart. He is alone, but for One who is ever with Him and understands Him. "No one knoweth the Son, save the Father" (Matt. xi. 27). 


\section{The Son of God}

A personality revealed in features such as these cannot be explained by the moral and spiritual life of the generation to which Jesus belonged, or of the generations that went before. It can only be explained by the unique experience of Jesus Himself. Everything we read about Him in the Gospels suggests His consciousness, not merely of a close, but of an unbroken communion with His Father in heaven. But about that inner life there is a notable reticence in His own sayings as recorded in the synoptic Gospels. There is, however, in the first and third Gospels one remarkable saying where the veil is lifted for a moment: "All things have been delivered unto me of my Father : and no one knoweth the Son, save the Father, neither doth any know the Father, save the Son, and he to whomsoever the Son willeth to reveal him " (Matt. xi. 27, cf. Luke x. 22). As far as the evidence of manuscripts and early Christian writers is concerned, this is a well-attested saying of Jesus - the expression of His own mind, and not merely the expression of the mind of the early Christian community about the personality of their Lord.

In these words we have an expression of the conviction of Jesus that $\mathrm{He}$ is more than $a$ Son of God. "Son of God" is an elastic phrase. In the Old Testament it is applied to angelic beings : "When the morning stars sang together, and all the sons of God shouted for joy" (Job xxxviii. 7); to 


\section{The Jesus of History}

judges or rulers : "I said, Ye are gods; and all of you sons of the Most High" (Psalm lxxxii. 6); to the King: "I will be his father and he shall be my son" (2 Sam. vii. I4). In the New Testament also the phrase has a wide application. For example, Jesus speaks of others as sons of God : "Blessed are the peacemakers, for they shall be called sons of God" (Matt. v. 9). But it is not in this general sense of the phrase Jesus regards Himself as Son of God. He is Son of God in a unique sense, the Son of God as no other is. "Of that day or that hour knoweth no one, not even the angels in heaven, neither the Son, but the Father" (Mark xiii. 32). And $\mathrm{He}$ is conscious of His unique sonship, because $\mathrm{He}$ is conscious of a unique oneness with God, of a unique fellowship with His Father-a fellowship uninterrupted by moral failure-, of a unique sympathy with the heart and will of God, and of a unique vocation to reveal the Father to His fellows.

The existence of such a unique personality, it is said by a certain school of New Testament scholars, cannot be accepted as an historical fact. The saying in which Jesus claims to be the Son of God in a unique sense was not uttered by Jesus Himself, but must be put down to the credit of the idealising faculty of His followers. By the canons of historical science such a unique personality must be ruled out as an impossibility, whatever evidence for it may be adduced. 


\section{The Son of God}

By all means, it may be said in reply, let historical science be conceded its fullest rights. But in this assumption of the impossibility of a unique personality in Jesus we have a "dogmatic" theory imposed upon, and restricting the rights of historical science-the theory, namely, that personality can be wholly accounted for by heredity and environment. But personality is not thus explicable. There is something more here than the resultant of the influences of heredity and environment. These influences may throw light upon the ways in which personality expresses itself ; they do not explain personality itself. Personality is " a main miracle." It is therefore, not historical science, but an unwarranted "dogmatic" theory of some representatives of historical science, which forbids us to entertain the possibility of such a " miracle of miracles" as the unique personality of Jesus.

It is precisely from loyalty to historical facts, and not from blind submission to the dogmas of the Church, that many a truth-seeker is led to recognise that in Jesus there has appeared a unique personality in the history of humanity. For it is here the clue is found to the understanding of the historical facts of the life of the Jesus of history, and to the understanding of the mighty historical movement of which He has been the leader and inspirer. 


\section{CHAPTER V}

\section{How Jesus Interprets His Death}

THE withdrawal of Jesus with His disciples from the ordinary scenes of the Galilean ministry to the greater seclusion of the district at the base of Mount Hermon marks a crisis in His career.

The story of the temptation in the wilderness of Judæa suggests that from the beginning of His ministry He had taken account of the difficulties with which $\mathrm{He}$ was faced in consequence of $\mathrm{His}$ revolutionary conceptions of the Kingdom of God and of the Leader in the Kingdom. Of these difficulties $\mathrm{He}$ has had abundant experience by the time $\mathrm{He}$ sets Himself, under the pressure alike of anxiety and of eager longing, to discover through a solemn talk with the Twelve how far they were prepared, in spite of the disappointment of many hopes they had cherished, to accept Him definitely as Leader in the Kingdom of God. The Pharisees and scribes, the acknowledged representatives of the popular religion, suspicious of the Prophet of Nazareth from the outset, and now avowedly hostile, are casting about for the means of foiling a movement which, by its insistence on goodness of heart and life, to the disparagement of observances 


\section{How Jesus Interprets His Death}

enjoined by the law and tradition, is menacing the whole organisation with which, as they believe, not only their personal interests, but the interests of religion and patriotism are bound up. Hostility is threatened from other quarters. Political zealots are amazed that $\mathrm{He}$ has so little interest in their revolutionary aspirations. Herod, on the other hand, fears lest $\mathrm{He}$ fan the slumbering fires of Jewish nationalism, and Sadducean priests at Jerusalem are not minded to let Jesus of Nazareth involve them in conflict with the Roman overlords, under whom they have enjoyed no small measure of worldly prosperity. Then, many of the common folk of Galilee, once eager to listen to His " words of charm," and responsive to the glad news that a new and better day was about to dawn, have begun to chafe under His imperious demands for a heroic goodness impossible to weak human nature. So at Cæsarea Philippi He finds Himself confronted with an array of hostile forces-common sense, political prudence, the strength of many a threatened vested interest, and, above all, zeal for God and religion, as God and religion were interpreted by the Pharisees.

He foresees that He must tread the way of suffering, but $\mathrm{He}$ foresees it with no surprise. It is true that in the earlier Galilean ministry He moved in an atmosphere of hope and joyousness. ${ }^{\mathrm{x}}$ Yet $\mathrm{He}$

I "L'air de fête," "au milieu d'une fête perpétuelle." Renan, Vie de Fésus, pp. 196, 189. 


\section{The Jesus of History}

was even then aware of the "Shadow of the Cross," if not so definitely as Holman Hunt's picture suggests. In answer to the question: "Why do John's disciples and the disciples of the Pharisees fast, but thy disciples fast not ?" He replied: "Can the sons of the bridechamber fast, while the bridegroom is with them ? as long as they have the bridegroom with them, they cannot fast. But the days will come when the bridegroom shall be taken away from them, and then will they fast in that day" (Mark ii. I8-20). The fate of the prophets, including John the Baptist, was early present to His mind. "Blessed are ye when men shall reproach you, and persecute you, and say all manner of evil against you falsely, for my sake. Rejoice and be exceeding glad: for so persecuted they the prophets which were before you " (Matt. v. I I, I2).

Besides, from the beginning $\mathrm{He}$ gave warning to those who would be His disciples that discipleship would involve them in difficulties and dangers, and would call for heroic readiness to suffer, even to lose life itself, for His sake.

It is therefore most improbable that in the earlier period of His ministry $\mathrm{He}$ anticipated a speedy and easily-won triumph, and that only in the later months did $\mathrm{He}$ realise the possibility of His own suffering and sacrifice as being the condition of the advent of the Kingdom. No; the way of suffering for the Leader was no afterthought on which He fell 


\section{How Jesus Interprets His Death}

back when He found that His early hopes were not to be realised.

At the same time, in the later months $\mathrm{He}$ speaks to the Twelve about "the things that were to happen unto Him " more frequently and pointedly than before. Immediately, it would seem, after Peter as spokesman for the Twelve answered the Master's question, "Who say ye that I am ?" with the great confession: "Thou art the Christ," $\mathrm{He}$ "began to teach them that the Son of Man must suffer many things, and be rejected by the elders, and the chief priests, and the scribes, and be killed" (Mark viii. 3I). In the following chapter of Mark's Gospel we read that Jesus and His disciples " passed through Galilee, and he would not that any man should know it. For he taught his disciples, and said unto them, The Son of Man is delivered up into the hands of men, and they shall kill him" (Mark ix. 30, 3I). In the next chapter we have a scene on the way to Jerusalem, which is described with a few vivid touches: "And they were in the way, going up to Jerusalem; and Jesus was going before them: and they were amazed; and they that followed were afraid. And he took again the twelve, and began to tell them the things that were to happen unto him, saying, Behold, we go up to Jerusalem, and the Son of Man shall be delivered unto the chief priests and scribes; and they shall condemn him to death, and shall deliver him unto 


\section{The Jesus of History}

the Gentiles " (Mark x. 32, 33). Then a little later we have the question to James and John in answer to their request for first places in the Kingdom of God : "Are ye able to drink the cup that I drink ? or to be baptised with the baptism that I am baptised with ?" (Mark x. 38). It is evident that in the months preceding the passion week at Jerusalem He was absorbed by the thought of His death. As Bengel has finely put it, habitabat in sua passione.

Not without struggle of soul did $\mathrm{He}$ contemplate "the things that were to happen unto him," as is indicated by His reply to Peter, when he remonstrated with Him for speaking of the suffering and death that awaited Him: "Get thee behind me, Satan: for thou mindest not the things of God, but the things of men" (Mark viii. 33). Peter's appeal to Him to give up the thought of going forward to such an issue of His career was the unwelcome reviving of a temptation, which $\mathrm{He}$ had resolutely resisted from the beginning of His ministry. Leadership in the kingdom through love and suffering, even unto death - that, He was sure, was God's mind about His vocation. To seek for escape from the way of the Cross-that, He was sure, was a suggestion of the Tempter. He was conscious of the temptation, $\mathrm{He}$ appreciated its atrractive power, but $\mathrm{He}$ crushed it back. "Get thee behind me, Satan." But His experience of struggle of soul did not then come to an end. From the time when 


\section{How Jesus Interprets His Death}

"He steadfastly set his face to go to Jerusalem" (Luke ix. 5I) there was no faltering, but there was " continuous moral volition." What a glimpse is given us into His experience, when we are told that as they were in the way, going up to Jerusalem, "Jesus was going before them: and they were amazed ; and they that followed him were afraid" (Mark x. 32). There is here some tense struggle, which startled and terrified the disciples. The evangelist gives us no interpretation of the meaning of this scene, but we have a clue to the interpretation in the account of the later struggle in the Garden of Gethsemane. Here Jesus comes to the climax of all His struggle of soul. The question obtrudes itself: Is there no way of fulfilling my vocation save by the way of suffering, self-sacrificing love? But the answer surges up from His own conviction reached long before. There is no other way: this way is God's way. It is His Father's love for His children which is urging Him towards the Cross, and to the claim of His Father's love $\mathrm{He}$ responds with resolute devotion. "Abba, Father, all things are possible unto thee; remove this cup from me: howbeit not what I will, but what thou wilt" (Mark xiv. 36).

Jesus regards the suffering which awaits Him as bound up with His vocation to be the Leader in the Kingdom of God. But this suffering is something 


\section{The Jesus of History}

other than a hard fate or a dark mystery, by which He is perplexed and unnerved. He sees it in another light. It is not a problem to be solved; it is an opportunity to be seized. He does more than accept it submissively; He welcomes it with a stern joy. He takes it into His life-plan, for $\mathrm{He}$ recognises in it the means of realising His life-aim.

He has a great vision of coming good for His fellows. He has great thoughts of what His fellows may be, of the heroic goodness to which they may rise, of the filial fellowship with His Father in Heaven, in which they may find the secret of peace of heart and of an eager courageous outlook. He has great thoughts of a Kingdom of God, in which the children of the one Father will be drawn into a brotherhood by a common faith, a common love and a common hope. And $\mathrm{He}$ believes that $\mathrm{He}$ has been called by God to be the Leader in the realisation of this vision. Love for His fellows inspired Him at the beginning to respond to the divine call, and love for His fellows has inspired His whole ministry. So, when $\mathrm{He}$ is steadfastly setting His face to go to Jerusalem, in love's strength $\mathrm{He}$ faces the worst that can befall Him. As the Leader and Protagonist, on whom the interests of the Kingdom of God depend, He can do no other.

The growing hostility with which $\mathrm{He}$ was being hemmed round opened up a way on which " $\mathrm{He}$ quite found Himself." From the beginning $\mathrm{He}$ 


\section{How Jesus Interprets His Death}

had believed in the power of love to break down the power of evil. He had appealed to His followers for a love strong enough to repay evil with good, to confront the wrongdoer with a forgiving temper, to triumph over wrong in love's own might. And now, as $\mathrm{He}$ enters upon the Way of the Cross $\mathrm{He}$ is sure that the power of forgiving, self-sacrificing love is the God-willed means of realising His vision of the Kingdom of God. His suffering is no mere painful experience inseparable from His vocation, no mere hard fate $\mathrm{He}$ has to endure; it brings an opening for the outflow of a love which will work with redeeming power upon the hearts of His fellows. Only through suffering can $\mathrm{He}$ fully express Himself; only through suffering can $\mathrm{He}$ be the Redeemer. So the love of Jesus inspires Him, not merely to accept His suffering, but to go out and welcome it. "I have a baptism to be baptised with; and how am I straitened, till it be accomplished!" (Luke xii. 50).

Jesus looked forward to His death, not as the end of His career, but as the beginning of wider and more effective leadership in the kingdom of God. By His blood the new covenant was to be definitely inaugurated. Through His death and His victory over death the Kingdom of God was to " come with power." 

THE CHRIST OF FAITH 

II

In the Apostolic Age 
In the apostolic age the Christian Society was largely guided by disciples of Jesus whom He had chosen to be His close companions. In their companionship with the Master they had much to learn and much to unlearn. They had to suffer many disillusionments, many strains on their loyalty. But in spite of all their doubts and questionings their loyalty stood the tests to which it was subjected. They put themselves to school with Jesus. At the cost of hard experiences they came to an ever-deepening understanding of His thoughts and aims. They strove, as far as they were able, to make these thoughts and aims their own. Impressed from day to day by the transforming power of His wonderful personality, they at last attained to a singular insight into His regnant ideals.

As leaders of the Christian Society the Apostles were thus peculiarly qualified to be interpreters of the mind of the Master. It is therefore natural that special regard has ever been paid to the apostolic age for an understanding of the genius of Christianity. That age reflects the regnant ideals of Jesus, as they were interpreted by those who had been admitted to a singularly close fellowship with Him from the beginning of His ministry to the day when $\mathrm{He}$ was crucified.

It is from this point of view that the apostolic age is considered in the following chapters.

To illustrate how the apostolic age gives expression to the ideals of Jesus, we select four topics for consideration-the Lordship of Jesus, the moral heat of the early Christians, the conception of God as God in Christ, and emphasis on the Christian Society. But we begin with a preliminary chapter on the early Christians' experience of the presence of the risen Jesus. It is only when we take this into account that we can duly appreciate the characteristic features of their thought and life. It is with a wonderful personality they have to do, who lived a truly human life in the past, but who is very near them in the present. They acknowledge Him as Lord, but He is no absent Lord, who has left lessons for them to accept; He is present to their hearts, bringing them under the power of His personality. They strive to fashion their lives according to His precepts, but behind all these precepts is the ever-present Teacher, who is more than all His precepts. They learn to think of God in the light of what He taught about His fatherly love and His fatherly fellowship with His children, but the presence of Jesus-spirit with spirit-is "God's presence and His very self." They are members of a Christian Society, with its fellowship and organisation, with its forms of worship and its varied activities, but what gives its meaning to all this is the presence and working of the Spirit of Christ. 


\section{CHAPTER VI}

\section{The Abiding Presence of Jesus}

Companionship with Jesus prepared the Twelve and other disciples for the singular experience that came to them after His death upon the Cross. That wonderful time of companionship, with the new outlook upon life it opened up for them, with the new hope it inspired, and the new gladness into which it introduced them, brought with it also the sore travail of a revolution in the religious beliefs they shared with their countrymen. Again and again they suffered the pain of disillusionment, for the Master was not realising their dreams of what the Messiah would be. But against all that, there was to be set the impression His companionship made upon them. What $\mathrm{He}$ had to say to them about the Kingdom of God, and about the kind of men the citizens of the Kingdom of God must be, appealed to heart and conscience, and gained an ever strengthening hold upon them. And behind all His words was the Teacher Himself, wholaid His power upon them. However He might disappoint their hopes, they became more and more 


\section{The Christ of Faith}

sure that the Kingdom of God must be what $\mathrm{He}$ interpreted it to be, and that $\mathrm{He}$ was the true Leader in the Kingdom. They had been discovering in their fellowship with the Master that the things about which $\mathrm{He}$ was supremely concerned were, after all, the things most worth living for, and were worth the perils and sacrifices in which their loyalty to Him might involve them. Their growing faith, however, was often sorely tried. Especially severe was the strain to which it was subjected, when $\mathrm{He}$ began to tell them that it was according to the mind of God that He should soon be put to death. How they contrived to explain away His repeated hints about the Cross, we can only conjecture, but in some fashion or other they found an explanation which blunted the edge of His forecast of what would happen at Jerusalem. So the crucifixion of their dear Master was a blow as unlooked for as it was staggering. Their loyalty had triumphed over one and another disillusionment. Would it stand the strain of this last and most tragical disillusionment? Could $\mathrm{He}$ who was nailed to the Cross on Calvary be the Messiah ?

Amid their bewilderment in the heart-breaking, faith-shaking hours they lived through after the crucifixion, one thing steadied them-their knowledge of His worthiness of leadership in the Kingdom of God. That was a basal conviction, which nothing, not even the crucifixion, could avail to beat 


\section{The Abiding Presence of Jesus}

down. And that may well have been the startingpoint for the quickening of memory and the stirring of questions. Did not the Master, they may have asked themselves, tell us again and again in the last months about the death that awaited Him in Jerusalem ? Did He not speak of His death as the will of God for Him, as something which was bound up with the interests of the Kingdom of God? Did He not seem in the last weeks to be looking forward to it, to be indeed hasting towards it, with a strangely eager longing? And when $\mathrm{He}$ spoke to us of His death, did He not say that He would rise again ? From the first days of our discipleship did we not have oft-repeated experience of the disappointment of our hopes, but in spite of multiplied disillusionments, did we not at Cæsarea Philippi express to $\mathrm{Him}$ our conviction that $\mathrm{He}$ was the Christ of God? Is there not a ray of light in the darkness? What if, after all, the death of the Master may somehow mean the coming of the Kingdom in power? What if, after all, the Master may be with us again? What if, after all, this fresh disillusionment may issue in a fresh discovery of $\mathrm{His}$ worthiness to be the Christ of God ?

Whatever may have been the thoughts and questionings which kept surging upon them in the dark hours after the crucifixion, their loyalty, though a terrible strain was put upon it, was not shattered. For there came to them an extraordinary experience 


\section{The Christ of Faith}

which was shared by none but the loyal-hearted. Jesus appeared to them. As we learn from St. Paul, from whom we have the first written account of what happened, "he appeared to Cephas; then to the twelve; then he appeared to above five hundred brethren at once, of whom the greater part remain until now, but some are fallen asleep; then he appeared to James; then to all the apostles" (I Cor. xv. 5-7). This appearance of Jesus was to the disciples too real to leave any room for doubt to arise in their minds. Its reality is vouched for by its effect upon them. II turned their dark despair into radiant hope, their unutterable sorrow into ineffable joy. In the light of the Master's victory over death they saw glory in the Cross of shame. Now they understood, as never before, His demand for a devotion to the Kingdom that would not shrink from the uttermost sacrifice; now they understood why He should have steadfastly " set His face to go to Jerusalem" (Luke ix. 5I). They had learned much in the old days about the strength and tenderness of His love for His fellows, but the love they now saw in the Cross of Calvary amazed them and laid its power upon them. His death was no longer a strain upon their loyalty; it was inspiration for more fervent loyalty. They could say with a new assurance: "Thou art the Christ." Every impression which had been made upon them by His teaching and by His personality 


\section{The Abiding Presence of Jesus}

was re-inforced and sealed. With the new light transfiguring suffering and death; with a new insight into the meaning of life and its possibilities, into the greatness and graciousness of God's purpose with His children, into the enterprise in which their risen Master was summoning them to be His fellowworkers, they were suddenly upborne on a full tide of faith and courage and joy.

The appearances of Jesus, to which witness is borne by St. Paul and the evangelists, were exceptional and had exceptional significance. But apart from such quite exceptional appearances, the disciples were conscious that the Master was still present with them. "Lo, I am with you alway" - they knew the truth of these words from their own experience. If $\mathrm{He}$ was no longer present with them in the body, it was only that He might be nearer them in spirit. "It is expedient for you that I go away : for if I go not away, the Comforter will not come unto you" (John xvi. 7). Even their longing for the Parousia-the second coming-of their Lord did not mean that $\mathrm{He}$ was an absent Lord. St. Paul shared the belief of the early Christians that Jesus would soon return, but his whole being was thrilled by the sense of His abiding presence. He lived " in Christ."

The Christians of the apostolic age may not all have risen to the height here reached by St. Paul, 


\section{The Christ of Faith}

but a sense of being in the presence and under the power of the personality of Jesus was an outstanding feature of their Christian discipleship. This was at the heart of their glowing life, their heroism and victorious energy; at the heart of their thoughts about God and duty and immortality; at the heart of their faith and hope and love. 


\section{CHAPTER VII}

\section{The Lordship of Jesus}

BEFORE those who were afterwards to be the chosen band of the twelve disciples knew Jesus they may have had a less legalistic temper and more affinity with the spiritual outlook of Amos and Isaiah than the majority of their contemporaries, but they, too, believed that the Jewish institutions and laws were bound up with the Kingdom of God, and they, too, expected that the new age would mean for the Jewish nation unwonted power and glory and happiness. In companionship with the Master their interpretation of the Kingdom of God was gradually and radically revolutionised.

Jesus did not at the beginning of His ministry make an explicit claim to be the Messiah, but $\mathrm{He}$ bore Himself as if He were the Leader in the Kingdom. That He might be the Messiah was no unfamiliar thought to the Twelve, but they were often disappointed, often puzzled. He was ever calling upon them for a good heart, for a seemingly impossible love, for a revision of their ideas of the true blessedness of life, of the true riches, of true greatness. 


\section{The Christ of Faith}

On the other hand, $\mathrm{He}$ had little to say about the establishment of such a Kingdom of God as would eclipse in power and glory the existing kingdoms of the world, and He seemed to be taking no steps for the inauguration of such a kingdom. But with open and loyal hearts they had put themselves to school with Jesus. Under the commanding influence of His personality and teaching they became more and more attuned to His mind; they learned to take His standards of worth. As the outcome of their growing appreciation of $\mathrm{His}$ novel interpretation of the Kingdom of God, they were at last able to say: "Thou art the Christ." The Father in Heaven had revealed it to them. Through their companionship with the Master, God had wrought such a revolution in their conception of life and its true greatness that they recognised in Jesus their rightful King, the Messiah promised to their fathers.

Thus the confession of the Messiahship of Jesus had for the first Christians a significance of a quite distinctive character. To confess Jesus as Messiah was to confess loyalty to His interpretation of the Messiah and the Messianic Kingdom, to confess loyalty to His ideals of life for the individual and for society. It was a confession that sifted men, for it was an acknowledgment that Jesus with His distinctive ideals was the true King of men, the rightful Lord of life. 


\section{The Lordship of Jesus}

For Jews who became Christians the fitting name to express this was the Messiah. But the important thing was not the name, but what the name stood for-lordship over the life of man. So, when Christian communities were springing up on Gentile soil, the designation of Jesus as the Messiah tended to fall into the background, and another designation, more intelligible to the Gentiles, and richer in its suggestiveness, came into familiar use. Jesus was usually designated, not the Messiah, but the Lord.

The confession of Jesus as Lord had the same import as the confession of Him as the Messiahwillingness, or rather a settled purpose to let the whole life be ruled by Jesus and His ideals. St. Paul seems to indicate that "Jesus is Lord" was a familiar formula for the expression of the essence of Christian discipleship. The rite by which converts were received into the Christian society was an acknowledgment of the lordship of Jesus. They were baptised "in the name of Jesus Christ" (Acts ii. 38), "baptised into Christ Jesus" (Romans vi. 3, Gal. iii. 27). In their baptism they pledged themselves to be servants of Jesus as Lord. Henceforth they were not their own, they belonged to the Lord who had bought them with a price (Rom. vi. 19, 20). Their daily life was to be ruled and inspired by Jesus. "Whatsoever ye do, in word or in deed, do all in the name of the Lord Jesus" (Col. iii. I7). For His sake, in obedience to what they believed to 


\section{The Christ of Faith}

be His will, they were to be ready for heroic, perilous ventures, ready to suffer many things, (Acts ix. I6) "to take pleasure in weaknesses, injuries, in necessities, in persecutions, in distress" (2 Cor. xii. Io), ready to be "delivered unto death" (2 Cor. iv. II).

This lordship of Jesus over the whole life was taken seriously by the early Christians. How seriously, is strikingly illustrated in a New Testament writing which comes to us from the close of the apostolic age-“"The Revelation of St. John the Divine." Here we see the Christians of Western Asia Minor in the time of the Emperor Domitian, confronted by the demand made upon them by the imperial authorities to take part in some act of Emperor-worship, and thereby acknowledge the Emperor as their supreme Lord. Suspicions had been aroused that the Christians were at heart disloyal to the Roman Empire, that however they might profess to be good subjects, they owed to Jesus the Founder of their religion a higher allegiance than to the Emperor, the centre and symbol of the mighty empire. So they were called upon to acknowledge supreme allegiance to the Roman Emperor, and to no other. They refused, no matter what the consequences might be; they could not disown Jesus as their supreme Lord. It was to hearten them in their hour of peril that "the Revelation of St. John the Divine" was written. It 


\section{The Lordship of Jesus}

was a trumpet-call to the Christians to be loyal to Jesus as "Lord of lords, and King of kings" (xvii. 14). "Fear not the things which thou art about to suffer," "Be thou faithful unto death" (ii. Io)from such rallying cries we learn something of what the early Christians meant when they made the confession : "Jesus is Lord," and we learn something of their loyalty to the mind of the Master who had said : "If any man cometh unto me, and hateth not his own father, and mother, and wife, and children, and brethren, and sisters, yea, and his own life also, he cannot be my disciple" (Luke xiv. 26). 


\section{CHAPTER VIII}

\section{The Moral Heat of the Earliest Christians}

No one can thoughtfully read the New Testament without becoming aware that those, for whom its various writings were in the first instance composed, had, or at least were expected to have an exceptional passion for goodness of life. In the Gentile world of that day there was no such close connection between goodness of life and religion, as we now almost take for granted there ought to be. There was virtuous life amongst the Gentiles. There were great ethical teachers, but it was not to the priests, the official representatives of religion, the people looked for ethical teaching, but rather to the philosophers. As compared with the Gentile religion with which it came into contact, Christianity was distinguished from the outset by the emphasis it laid upon goodness of life. In this respect it served itself heir to the best traditions of the Jewish religion. To the Jews, even when the teaching of their great prophets had been obscured by the legalism of later days, it was a fundamental principle that righteous living was the only true 


\section{The Moral Heat of the Earliest Christians}

service of God-a feature of their religion which goes far to explain why so many Gentiles attached themselves as proselytes to the Jewish communities which were to be found in many cities of the GræcoRoman world. This fundamental principle of the Jewish religion was taken over by the Christians, but interpreted in a nobler way. Goodness of life was indissolubly bound up with their religion, but they had a new ideal of goodness, and were conscious of new power at their command for realising it.

St. James, ${ }^{\mathrm{x}}$ a Christian Jew, writing to fellow Christians outside Palestine, is impatient with religion which does not express itself in goodness of life. "If any man thinketh himself to be religious, while he bridleth not his tongue but deceiveth his heart, this man's religion is vain. Pure religion and undefiled before our God and Father is this, to visit the fatherless and widows in their affliction, and to keep himself unspotted from the world "(James i. 26, 27). "But wilt thou know, $\mathrm{O}$ vain man, that faith (that is, assent to religious doctrine) apart from works is barren "(James ii. 20). It may be said-it was said by Luther, who described this epistle as "strawy,"-that James is here not quite in line with the rest of the New Testament, that he is one-sided in the emphasis he lays upon

I If the Epistle of James is one of the latest, and not, as was formerly believed, one of the earliest writings in the New Testament, its significance for our present purpose is not lessened. 


\section{The Christ of Faith}

"works," upon "mere morality," that he throws into the background the spiritual experience in which alone true goodness has its root. It might be said in reply, that this spiritual experience is taken for granted, and that for the particular purpose he had in view it was not necessary for him to enlarge upon it. Be that as it may, the fact that this letter of his was regarded as of great worth by the early Christians, and found eventually a place in the collection of New Testament writings, is of itself sufficient to suggest that emphasis on the closeness of the connection between religion and morality belongs to the genius of Christianity.

The author of " the first epistle general of John" cannot be said to throw spiritual experience into the background, but he is no less emphatic than James in demanding that religion express itself in goodness of life. "He that saith he is in the light, and hateth his brother, is in the darkness" (I John ii.9). "Whosoever doeth not righteousness is not of God" (I John iii. Io). "He that loveth not his brother whom he hath seen, cannot love God whom he hath not seen" (I John iv. 20). "He that loveth not, knoweth not God; for God is love" (I John iv. 8). " "This is the love of God, that we keep his commandments" ( $\mathrm{I}$ John v. 3 ).

Just as little as St. John does St. Paul throw spiritual experience into the background. Yet it is from him we have these impassioned words : 


\section{The Moral Heat of the Earliest Christians}

"If I speak with the tongues of men and of angels, but have not love, I am become sounding brass or a clanging cymbal. And if I have the gift of prophecy, and know all mysteries and all knowledge ; and if $I$ have all faith, so as to remove mountains, but have not love, I am nothing . . . Love never faileth: but whether there be prophecies, they shall be done away; whether there be tongues they shall cease; whether there be knowledge it shall be done away. . . . But now abideth faith, hope, love, these three; and the greatest of these is love" ( I Cor. xiii. I, 2, 8, I 3).

The New Testament writers take for granted that the Christians whom they address are to be recognised by the Gentiles amongst whom they live, as good men and women. So they exhort them with affectionate earnestness to be on their guard against any kind of behaviour which would lower them in the esteem of their non-Christian neighbours. "Do all things without murmurings and disputings; that ye may be blameless and harmless, children of God without blemish in the midst of a crooked and perverse generation " (Phil. ii. I 5). "Take thought for things honourable in the sight of all men" (Romans xiii. I7) "I beseech you as sojourners and pilgrims, to abstain from fleshly lusts, which war against the soul; having your behaviour seemly among the Gentiles" (I Peter ii. I I, I2). 


\section{The Christ of Faith}

So keenly concerned is St. Paul about his converts commending themselves by the goodness of life which appeals to the common conscience, that he bids them go to school even with non-Christians; to be on the look-out for, and let themselves be influenced by, whatever is worthy in their life. "Whatsoever things are true, whatsoever things are honourable, whatsoever things are just, whatsoever things are pure, whatsoever things are lovely, whatsoever things are of good report; if there be any virtue, and if there be any praise, think on these things" (Phil. iv. 8).

Let us notice one or two of the outstanding features of goodness of life, as interpreted by the Christians of the apostolic age.

I. Jesus was not content with righteous conduct which was merely external obedience to statutory precepts. He was ever driving His hearers back upon the inner world of motive, ever demanding a good heart as the indispensable condition of true righteousness. Here the Christians of the apostolic age were loyal to the ideals of their Lord. One thing which differentiated them from the average Jew was the exceptional emphasis they laid upon what lay behind and inspired good conduct. For example, less was made of "law," and more of love. "For the whole law," says one New Testament writer, " is fulfilled in one word, even in this; 


\section{The Moral Heat of the Earliest Christians}

Thou shalt love thy neighbour as thyself" (Gal. v. I4). "Love worketh noill to his neighbour: love therefore is the fulfilment of the law" (Rom. xiii. Io). "If," says another writer, "ye fulfil the royal law, according to the Scripture, Thou shalt love thy neighbour as thyself, ye do well" (James ii. 8). And there is another mode of expression which the New Testament writers use, to throw into relief their sense of the worth of the motive which inspires good action, their sense of the worth of what Jesus spoke of as "the good heart." They speak of the spirit as the source of the goodness of life. "The letter (that is, the law) killeth, but the spirit giveth life" (2 Cor. iii. 6). "If ye be led by the Spirit ye are not under the law. . . The fruit of the Spirit is love, joy, peace, longsuffering, kindness, goodness, faithfulness, meekness, temperance" (Gal. v. 18, 22, 23).

2. The Christians of the apostolic age were expected to come up to the highest standards of conduct recognised by their non-Christian neighbours, but they were expected to have still higher standards, to do "more than others." Heroic goodness was to be no rare achievement; it was to be a habitual feature of their Christian discipleship.

In their treatment, for example, of wrongs done to themselves: "Render to no man evil for evil - . Overcome evil with good" (Rom. xii. 17, 2 I) "See that none render unto any one evil for evil; 


\section{The Christ of Faith}

but alway follow after that which is good, one toward another and toward all" (I Thess. v. I 5). "This is acceptable, if for conscience toward God a man endureth griefs, suffering wrongfully.

If, when ye do well, and suffer for it, ye shall take it patiently, this is acceptable with God. For hereunto were ye called" (I Peter ii. 19, 20). "Not rendering evil for evil, or reviling for reviling, but contrariwise blessing" (I Peter iii. 9).

Again, they were expected to rise to heroic heights in serving others; to humble themselves, to forget themselves, to sacrifice themselves, even as Jesus had done. "Have this mind in you," says one who was no quietist, but a born fighter, " which was also in Christ Jesus who . . emptied himself, taking the form of a servant, being made in the likeness of men; and being found in fashion as a man, he humbled himself, becoming obedient even unto death, yea, the death of the cross" (Phil. ii. 5-8).

Again, a heroic temper was looked for in their attitude to suffering-something nobler than a brave stoical endurance. Jesus had looked forward to His death with a certain wistful eagerness, as if He were sure that by His passion the purpose which His love inspired would be furthered. So the early Christians had a genius for welcoming rebuffs, for " rejoicing in tribulation." Their trials were often less a problem which perplexed them than an 76 


\section{The Moral Heat of the Earliest Christians}

opportunity to be turned to " glorious gain." "Most gladly therefore," says one, "will I rather glory in my weaknesses, that the strength of Christ may rest upon me" (2 Cor. xii. 9). "Count it all joy," says another, "when ye fall into divers temptations" (James i. 2). "Insomuch," says another, " as ye are partakers of Christ's sufferings, rejoice" (I Peter iv. I3). To be " crucified with Christ," to share the love which inspired the crucified Master, and so to share His joy ; to rejoice in suffering and fill up that which was " lacking of the afflictions of Christ" (Col. i. 24) - that was an ideal which urged them towards the moral heights.

3. Another feature of their ethical life is their exceptional consciousness of an ideal which is ever outstripping attainment. When the moral ideal is interpreted as chiefly obedience to statutory precepts, imposed from without, the door is opened for the entrance of that self-righteous temper, which is fatal to increasing growth in goodness. But the Christians laid the emphasis on loyalty to "the law of the spirit of life in Christ Jesus" (Rom. viii. 2). The moral ideal, just because it lived in and swayed heart and conscience, was an infinite ideal. Every attainment in the life of the spirit of Christ Jesus but served to kindle the vision of a yet higher attainment. As was confessed by one, the passion of whose life was to "know Christ and the fellowship of his sufferings": 


\section{The Christ of Faith}

"I count not myself yet to have apprehended : but one thing I do, forgetting the things which are behind, and stretching forward to the things which are before, I press on toward the goal" (Phil. iii. I3, I4).

The writers of the New Testament, by reminding, as they so often do, those whom they address that they are to aim at nothing less than likeness to Christ, cannot but suggest that their attainments, however great they may be, ever fall short of the ideal ; as Jesus suggested when He called upon His hearers to be perfect as their " heavenly Father is perfect." Again and again, Jesus is set forth as the Christian's moral ideal. "Walk in love even as Christ also loved you " (Eph. v. 2). "Be ye imitators of me, even as I also am of Christ" (I Cor. xi. I). "Consider him that hath endured such gainsaying of sinners . . . , that ye wax not weary, fainting in your souls" (Heb. xii. 3). "Christ also suffered for you, leaving you an example that ye should follow his steps . . . . who, when he was reviled, reviled not again; when he suffered, threatened not; but committed himself to him that judgeth righteously" (I Peter ii. 21-23).

At the close of the apostolic age little Christian communities were to be found in many of the cities adjoining the Mediterranean sea. The members of these communities were mostly humble folk : many 


\section{The Moral Heat of the Earliest Christians}

of them mere slaves. They were not distinguished by their culture, by their social standing, or by any kind of "worldly" success. But one distinction they they did have. They had lofty ideals of goodnessimpracticably lofty, as it seemed to onlookers-and they strove to be loyal to their ideals in their daily life. That singular moral heat of theirs could not but arrest attention. Where it came into contact with neighbours sympathetic enough to appreciate its nobility, it proved an attractive force. It was a fire that kindled fire in other souls. And it was a chief factor in the spread of Christianity: men saw the good works of the Christians, and glorified their Father in heaven. 


\section{CHAPTER IX}

\section{God in Christ}

THE New Testament, in comparison with contemporary Jewish writings and with the Old Testament, is distinguished by the frequency and warmth with which the writers speak of God as Father. The fatherly love of God was evidently one of their regnant thoughts. The phrase "God and Father of our Lord Jesus Christ " suggests that they were conscious of owing this regnant thought to Jesus. On this point St. Paul throws an interesting sidelight. "God," he says, "sent forth the Spirit of his Son into our hearts, crying, Abba, Father" (Gal. iv. 6). "Ye have received the spirit of adoption, whereby we cry, Abba, Father" (Rom. viii. 15) -as if the early Christians loved to use, untranslated into Greek, the very word with which Jesus, as the companions of His ministry were wont to tell, was in the habit of addressing Godthe Aramaic "Abba."

But from Jesus they received much more than new teaching about the Fatherhood of God; they received as the words just quoted from St. Paul 


\section{God in Christ}

indicate, a new experience of God-the spirit of sonship. This great experience stirred wonder and thanksgiving and adoration: "Behold what manner of love the Father hath bestowed upon us, that we should be called children of God : and such we are" (I John iii. I). For the spirit of sonship-the life of trustful filial fellowship with the God and Father of the Lord Jesus Christ-meant so much. It meant freedom, and freedom of the noblest, widest kind. "Thou art no longer a bondservant, but a son ; and if a son, then an heir of God" (Gal. iv. 7). "Ye received not the spirit of bondage again unto fear The Spirit himself beareth witness with our spirit, that we are children of God, heirs of God, and joint heirs with Christ" (Rom. viii. I 5, I6). It meant an "unconquerable mind" in presence of the worst that life could bring them; it meant courage, victorious energy, unconquerable hope. "We know that to them that love God all things work together for good . . . If God is for us, who is against us ? . . . For I am persuaded, that neither death, nor life, nor angels, nor principalities, nor things present, nor things to come, nor powers, nor height, nor depth, nor any other creature, shall be able to separate us from the love of God, which is in Christ Jesus our Lord " (Rom. viii. 28, 3I, $38,39)$. It meant the incoming of gracious power for the moral conflict. A father not only sets before his child an ideal of goodness, he backs up his effort 


\section{The Christ of Faith}

to realise it with the manifold resources of a wise and loving fellowship. So God the Father is the inspirer as well as the ideal of goodness. His grace is with His children "both to will and to work" (Phil. ii. I3). The life of sonship with the God and Father of the Lord Jesus Christ is an inexhaustible reservoir of moral strength.

With this experience of sonship with God it was inevitable that the early Christians should have a vivid sense of the presence of God to the heart. The imagery of a trustful, loyal child in fellowship with a loving father-the imagery of which Jesus made constant use-was a means, as simple as it was beautiful, of giving expression to what they felt God to be to them. And they pressed it into their service. But they had resort to other modes of expression. From the day of Pentecost onwards they spoke much of the Spirit, of the presence and working of the Spirit in their hearts. By means of this phraseology they gave expression to their conviction that God was not the far-off God He often seemed to be to the Jew and to the Gentile; that $\mathrm{He}$ was " nigh them, in their heart." They were not theologising about the nature of the Godhead in itself, they were concerned with what God was to themselves, with their own experience of GodGod "closer to them than breathing, nearer than hands and feet." Even so great a thinker as St. Paul is so engrossed with this experience of God, 


\section{God in Christ}

that, in speaking of the Spirit, he expresses his thought with a freedom of language which has sometimes perplexed theologians. For example, he identifies the spirit, the spirit of God, and the spirit of Christ. "But ye are not in the flesh, but in the spirit, if so be that the spirit of God dwelleth in you. But if any man hath not the spirit of Christ, he is none of his" (Rom. viii. 9).

There is a revelation of God in the teaching of Jesus on the fatherly love of God, and still more in the life He Himself lived as a Son with the Father. But the early Christians, as represented by their writings in the New Testament, carry our thoughts still higher. It is in Jesus they see the God with whom they have to do. It is in Jesus they discover the heart and will of God. It is in Jesus they know the Father. It is in Jesus they have "the true God" (I John v. 20).

St. Paul expresses this great thought in a pregnant phrase-God in Christ. "God was in Christ reconciling the world unto himself" (2 Cor. v. 19). The love of God is the love revealed in Jesus. "Neither death nor life . . . nor any other creature shall be able to separate us from the love of God, which is in Christ Jesus our Lord" (Rom. viii. 37-39). Without using the phrase "God in Christ" he expresses the thought it embodies, when he speaks of God shining in his heart " to give the light of the 


\section{The Christ of Faith}

glory of God in the face of Jesus Christ" (2 Cor. iv. 6).

The author of the Epistle to the Hebrews speaks in his opening sentences of Jesus as "the effulgence of God's glory, and the very image of his substance " (i. 3), and St. Peter reminds his readers that through Christ they are believers in God (I Peter i. 2I).

In the fourth Gospel the same great thought is expressed with a striking simplicity. "Philip saith unto him, Lord, shew us the Father, and it sufficeth us. Jesus saith unto him, Have I been so long time with you, and dost thou not know me, Philip? He that hath seen me hath seen the Father; how sayest thou, Shew us the Father ?" (John xiv. 8, 9).

For the first Christians, then, God was God as seen in Jesus. They could no longer think of God apart from Jesus. If the Jews were distinguished by their belief in one God and in one God as righteous will, the Christians were distinguished by their belief in God as God in Christ. Nor did they thereby cease to believe in one God. There is no trace in the New Testament of any approach to a conception of two Gods-the absolute God and God in Christ. They believed in one God (I Cor. viii. 6)-the one God they found in Jesus. This God was the only true God.

This thought of the revelation of God in Jesus, who was a true man and lived a truly human life, 


\section{God in Christ}

was new. It was, therefore, natural that amongst the early Christians attempts should be made to give expression to it in thought-forms which would convey a more or less adequate meaning to the men of that generation. Jesus Himself had used one significant phrase; He spoke of Himself as the Son. The majority of the members of the Christian society may have felt no great need of searching for further formulæ to express their conviction that in Jesus their Lord they knew the Father, the Father's heart and will. But some of them did feel such a need. For their own sake, and for the sake of others, they sought how they might give as full intellectual expression as possible to their conviction that the Father was revealed to them in the Son. Hence arose the Christology, or rather the Christologies, of the apostolic age. Christian thinkers, with a similar bent for relating their Christian faith to their thought-world, had each his own individual way of stating how he construed the revelation of God in Jesus. How he construed it, was largely determined by his own mental furniture, and by what he believed to be the mental furniture of those to whom he spoke or wrote.

St. Paul was familiar with Jewish speculations about a "heavenly man" (I Cor. xv. 45-49), who pre-existed from the beginning of the creation, and who was no mere man such as exists on earth, 


\section{The Christ of Faith}

but a heavenly being, who belonged to the sphere of God. These Jewish speculations he seems to have turned to more or less account in interpreting the revelation of God in Jesus, who " though he was divine by nature, did not snatch at equality with God but emptied himself by taking the nature of a servant ; born in human guise, and appearing in human form, he humbly stooped in his obedience even to die, and to die upon the Cross" (Phil. ii. 6-8, Moffatt's rendering). And with the same end in view he turns to account the speculations of Greek philosophy. When he speaks of " one Lord, Jesus Christ, through whom are all things, and we through him " (I Cor. viii. 6), and when he thus expands this thought in writing to the Colossians: "the image of the invisible God, the first born of all creation ; for in him were all things created, in the heavens and upon the earth . . . all things have been created through him and unto him; and he is before all things and in him all things hold together" (i. 15, 16), he is pressing into his service conceptions which would be readily intelligible by those who were familiar with the popular teaching of Stoic philosophers. Only, it was novel and amazing to have such conceptions applied to one who had lived a man amongst men. And this novel and amazing thing was done still more explicitly by a Christian thinker who wrote a generation later than St. Paul. 


\section{God in Christ}

In the prologue to the fourth Gospel the author brings his readers quite frankly into the atmosphere of contemporary Greek philosophy. Thinkers who came under the influence of Platonic and similar speculations tended to conceive the ultimate ground of all things (that is, to conceive God) as unknowable, indefinable; One who is so absolute, so incapable of entering into any direct relation with anything finite that the gulf between Him and the created universe must be bridged by some intermediary. Speculative imagination busied itself with an intermediary - the Logos-by whom the created universe was called into being, and who was the source of the divine reason expressed in the created universe. The Logos was the comprehensible image of the incomprehensible, hidden God. Jewish thinkers, like Philo of Alexandria, who aimed at commending the religion of their fathers to cultured Gentiles, worked with this conception of the Logos as the image of the invisible God, and found affinity between the Logos and Wisdom as described in the Book of Proverbs and in the Wisdom of Solomon. The prologue to the fourth Gospel seems to have been written with a view to Gentiles and Jews who were familiar with, and attracted by such speculations. But the author of the fourth Gospel does not accept the conception of the incomprehensible God, which is the basis of these speculations. Nowhere in the fourth Gospel or in the 


\section{The Christ of Faith}

Johannine Epistles is there any hint that God is not in direct relation with the created universe or with the children of men. There is only one thing in these speculations which the Prologue turns to account. The author is aware that the question is being asked: What is God in His relation to man ? To that question he answers: In Jesus is the true revelation of God. Jesus, who lived a truly human life, is the Logos, the true expression of the thought and will of God. Thus the Prologue is but making use of current philosophical speculations to commend to those who are familiar with them the great truth enshrined in the simple unphilosophical words: "He that hath seen me hath seen the Father" (John xiv. 9).

Such are illustrations of the various ways in which the early Christians stated how they construed the revelation of God in Jesus. Their particular way of relating the revelation of God in Jesus to the thought-world of their own time was not the important thing. What they were concerned with was the fact that the God with whom Christians had to do was God revealed in Jesus. Neither St. Paul nor St. John asks assent to a Christological theory. What both are intent upon is the confession of Jesus as Lord-Lord of the Christian in his thoughts of God, as in the whole sphere of his life-aims and activities. 


\section{CHAPTER $\mathrm{X}$}

\section{The Fellowship of the Disciples of Jesus}

In the apostolic age Christian discipleship was closely linked with the Christian Society. There never was a stage when Christianity was represented merely by a number of individual Christians. The Christian Society was in existence immediately after the crucifixion and resurrection of Jesus. In germ it was in existence from the days of His Galilean ministry. His convictions about God as the Father of the one great family of mankind, about the supremacy of love and love-inspired service, about the Kingdom of God, involved the Christian Society. In this sense, at least, the Christian Society was the creation, not of disciples of Jesus, who resolved to draw together for the furtherance of their common aims, but of Jesus Himself. Nor did the early Christians need any explicit instruction of Jesus to band themselves together in a society : the society was simply inevitable. Those who were swayed by devotion to the one Lord, who sought to serve the loving Father by serving His children in love, and whose hope was fixed on the coming of the 


\section{The Christ of Faith}

Kingdom of God, could not but be drawn into close fellowship with one another. Only through the manifold influences of such fellowship could they duly foster that life in which they found their chief good-life according to the ideals of Jesus. It was a true instinct, that is, an instinct true to the mind of Jesus, which led them to make much of the Christian Society.

That the early Christians made much of the Christian Society is evidenced by the importance they attached to Baptism. They could not well conceive of an unbaptised Christian, or, at least, of a Christian who resolved to remain unbaptised. Not that by the administration of the rite a man was supposed to be "made" a Christian. If the confession "Jesus is Lord" (that is, the sincere acceptance of the lordship of Jesus) was the mark of Christian discipleship, a man must have been a Christian before he was baptised. It was precisely because he was already a Christian that he asked, and was granted, initiation into the Christian society. At the same time, there could not well be a worthy acceptance by any one of the lordship of Jesus, which did not have its issue in the rite by which he was solemnly received into the fellowship of the Christian Society. And the administration of Baptism, in the realised presence of the one Lord of all, and in the atmosphere of the faith and love and hope of the assembled congregation, may well 


\section{The Fellowship of the Disciples of Jesus}

have been the occasion of a special experience of the power of the Spirit.

From the day of their Baptism the Christians lived the life of discipleship in the fellowship of their fellow-disciples. "They continued steadfastly in the apostles' teaching and in fellowship, in the breaking of bread and the prayers" (Acts ii. 42). "The multitude of them that believed were of one heart and soul" (Acts iv. 32). "That which we have seen and heard declare we unto you also, that ye also may have fellowship with us" (I John i. 3). "If we walk in the light, as he is in the light, we have fellowship with one another" (I John i. 7). Wherever we meet an individual Christian in the New Testament, we see him as a partner in the ample and gracious fellowship of the Christian Society. He is no lonely warrior; he is a unit in a noble army, by whose comradeship he is heartened. He draws on the common stock of his fellow Christians for the nourishment of his own devotion to Jesus and His ideals. $\mathrm{He}$ is ever beset by a life greater than his own. It is therefore by no accident that the most solemn Christian rite has the semblance of friends assembled for a social meal round a common table. The Lord's Supper is the culminating expression of the indispensableness of the fellowship of the Christian Society.

From the glimpses into the life of a Christian community which St. Paul gives us in his epistles 


\section{The Christ of Faith}

we learn much of what such fellowship meant. For example, in the first epistle to the Corinthians (xii. 4-II) we have a picture of a Christian community, whose bond of union is the same spirit, the same Lord, the same God who worketh all things in all. Each member has his own particular gift - "grace-gift" as the Greek word charisma, has been happily rendered. Each member has not only something to receive from, but also something to contribute to the common stock of spiritual wealth - the word of wisdom, or the word of knowledge, or faith, or gifts of healing, or workings of powers, or prophecy, or discernings of spirit, or divers kinds of tongues, or the interpretation of tongues. All the members are Christ-inspired, and as Christinspired they have all some special function to perform in strengthening the life of the community. The community is likened to the body which has many members, each of which-hand and foot, ear and eye-has its own special service to render to the efficiency of the one body (I Cor. xii. 12-27).

Even a society of Christ-inspired men and women has need of some sort of organisation, if the ends for which it exists are to be attained. "Let all things," says St. Paul to the Corinthians, " be done decently and in order . . God is not a God of confusion, but of peace" (I Cor. xiv. 40, 33). Organisation had its place in the Christian Society, as it must have its place in any conceivable society. 


\section{The Fellowship of the Disciples of Jesus}

But this organisation was not something ready-made at the outset; it was a growth. We can see it growing. In the appointment, for example, of the "Seven" (Acts vi. I-6) who were called into existence to deal with a difficulty which had arisen as to the distribution of the common fund of the Christian community to the widows. If St. Paul's pictures of a Christian community suggest a differentiation of the functions of the different members in the exercise of their "grace-gifts," rather than a differentiation of offices, yet they suggest more or less clearly a growing differentiation of officebearers-" "presbyters" (or "bishops," for the two names are used for the same person), " prophets," " pastors," " evangelists," " teachers." I

The growth of the Christian Society had its outcome in the growth of organisation to deal with new situations. But there is little evidence that the Christians of the apostolic age appealed to definite instructions from Jesus as the sanction for their development of organisation, or that they conceived themselves as laying down rules which were to be binding on all subsequent generations. The organisation of the Christian Society was rudimentary, still in the making. Just on that account we can the more fully recognise the strength of the inward bond-devotion to Jesus and His ideals-

I The apostles must always have been regarded as office-bearers invested with special authority. 


\section{The Christ of Faith}

by which its members were knit to one another in a singularly intimate fellowship.

What thus stands out as the chief bond of the Christian Society of that age, is not a common organisation, but a common spiritual life. This receives further illustration, if we consider the relation to one another of the Christian communities-the ecclesice-established in many different cities and countries. Each of these might be spoken of as an ecclesia-the church in a particular city or district. But each individual ecclesia was a part, or rather the representative of the one ecclesia, the one society, whose members were inspired by devotion to the one Lord. Membership in the individual ecclesia carried with it membership in the one ecclesia, and the mutual sympathies and services which such membership involved. It was not left to the individual ecclesia to choose to link itself with the one ecclesia. The confession of Jesus as Lord could not be truly lived out without the recognition of the bond by which all who acknowledged the one Lord were linked to each other. The unity of the ecclesia was deep-rooted in what constituted the essence of Christian discipleship-the confession of the lordship of Jesus.

The sense of the importance of preserving and fostering the unity of the many different ecclesice was exceptionally strong in the apostolic age. Witness the unwearied efforts, with which St. Paul strove 


\section{The Fellowship of the Disciples of Jesus}

in the face of formidable difficulties to guard against the possibilities of schism over the question of the relation of Gentile converts to the Jewish law. There was as yet little of that organisation by which in later times visible expression was given to the unity of the Church. But just for that reason, it is the more strikingly made manifest that the real unity of the Church is centred in the spiritual life of its members, in the "one spirit . . . one Lord, one faith, one baptism, one God and Father of all " (Eph.iv. 4, 5); and that no outward organisation expressive of the unity of the church, however desirable or even necessary it may be, can be a substitute for " the unity of the spirit." 



\section{III}

In the Subsequent Centuries 
In this section the question raised is this: In the development which took place after the apostolic age, was there such a departure from the ideals of Jesus as to justify either of these two theses : (I) that there is no warrant from the Jesus of history for the unique place assigned to Him by the Christian Society in its faith and worship, and for the unique emphasis laid upon the Christian Society itself ; (2) that in the development of Christian worship, the Christian ministry and Christian doctrine there has been in some directions serious aberration from the ideals of Jesus.

For an answer to this question the whole range of the history of the church offers material. For our present purpose it will be sufficient to restrict attention to a small part of the wide field. Special attention will be directed to the early centuries, as the process of development can be there most instructively studied, and what we learn from our survey of development in that period will render it unnecessary to enlarge upon developments in the later centuries. 


\section{CHAPTER XI}

\section{The Fact and Legitimacy of Development}

In the apostolic age the leaders of the Christian Society were for the most part Jews, and a large proportion of the members had been Jews, or had come under the influence of the Jewish religion before their conversion. By the beginning of the second century a change had taken place, or, at least, was in process of taking place. The proportion of Jewish to Gentile Christians was steadily growing less. The Jews, both in Palestine and in the "Dispersion," seem to have become, not less but more inaccessible to the appeal of the Christian Society than in earlier years. On the other hand, the appeal to the Gentiles was evoking an ever-growing response, and the leadership of the Christian Society was passing more and more into the hands of Gentile Christians. By the beginning of the second century it was becoming evident that it was amongst the Gentile peoples the Christian Society was to find its special field. The new situation created new problems. How to adapt the Christian message to the needs of the Gentile world, and how to find 


\section{The Christ of Faith}

a suitable organisation for the ever-increasing Christian communities in Gentile lands-such were some of the problems, which inevitably demanded fuller consideration than was necessary in the first century.

Of the darker features of the life of that GræcoRoman world in whose environment the Christian Society from the beginning of the second century was to make its appeal on behalf of its Lord, and on which it was destined to exercise an influence as profound as it was beneficent, the picture has been often drawn. We have been told the story of the misery and degradation involved in the wide-spread institution of slavery; of " man's inhumanity to man" as evidenced by the popularity of the "spectacles" in the amphitheatre, in which countless human beings, in contest with one another or with wild beasts "were butchered to make a Roman holiday"; of the deep depravity which had eaten like a canker into the life of many men and women in all classes of the community. It was with reference to that darker side of the Græco-Roman civilisation that Matthew Arnold pronounced his trenchant finding :

Stout was its arm, each thew and bone Seemed puissant and alive-

But oh! its heart, its heart was stone, And so it could not thrive! 


\section{The Fact and Legitimacy of Development}

On that hard pagan world disgust

And secret loathing fell.

Deep weariness and sated lust

Made human life a hell. ${ }^{\text {I }}$

The forces which were at work on behalf of a humaner and purer life emanated too seldom from the representatives of the popular religions. It was not even recognised, as it is in our modern Christian world, that there ought to be the closest connection between religion and morality. The popular polytheism - and this polytheism, however it might be discarded by the more intelligent, had still an immense vitality-often tended towards the palliation, even towards the encouragement of immorality. Nor was religion the spring of that confidence and hope in presence of life's wrongs and sufferings, which it seems natural to us to associate with it. Fear of the malign influence of the demons was to many persons a constant torment. "Without God and without hope" is an apt description of their plight.

But in this Græco-Roman civilisation there was a brighter side which has to be taken into account.

The outstanding political feature of the timethe Pax Romana-even if it had certain sinister effects, meant much for the well-being of humanity. The Roman Empire imposed peace upon quarrelsome races; it strove to introduce wiser and juster

Xbermann Once More. 


\section{The Christ of Faith}

laws among the peoples brought under its rule; it opened up opportunities for bringing the subjects of the Emperor into closer touch with one another; it worked for some sort of unity amongst a multitude of peoples, diverse in race and language, culture and religion - all this, indeed, at the cost of repressing independent national life, even where the people, as in the case of the Greeks and Jews, stood for a civilisation superior in many respects to that of the Romans.

In the moral and religious life of the GræcoRoman world there were brighter features to set over against the darker features. Rome was rich in worthy traditions of virtuous and heroic lives, and she had served herself heir to the ampler traditions enshrined in the literature of conquered Greece. Throughout the Roman Empire there was, among the educated classes at least, a growing alienation from the popular religions and a growing tendency to turn to Greek philosophy in one or other of its many forms for the satisfaction of their religious instincts. Of Stoicism it is especially true that it was the working religion of an ever-growing number of serious-minded people, and what such a religion could do for them is revealed in the discourses of Epictetus, and the Meditations of Marcus Aurelius. Nor were the Stoic teachers merely professors of philosophy in the lectureroom. Many of them went among the people with 


\section{The Fact and Legitimacy of Development}

a religious message for their fellows. Inspired with missionary zeal, they went from city to city, attracting crowds to their addresses. That their teaching had filtered down to the common people, we may infer from this one fact, that St. Paul, in his speeches and letters, seems to take for granted some familiarity, on the part of his hearers and readers, with the ideas and phraseology of Stoicism.

Besides the influence of popularised Greek philosophy, account has to be taken of the wide vogue of what have been called " mystery religions." Greece had long had its mystery religion at Eleusis, but after the closer contact of Greece with the Orient in the Hellenistic period, the popularity of mystery religions was increasingly a feature of the religious life of the Græco-Roman world, not only in the East but also, if to a less extent, in the West, even in the capital of the empire. Mystery religions associated with such divinities as the Phrygian Cybele, the Egyptian Isis and, later in time, the Persian Mithra, were spreading everywhere. They had all certain common features which go far to explain the success of their appeal. They were not national religions; that is, they were not systems of venerable ceremonies for securing national stability, they aimed at satisfying the religious aspirations of the individual soul. The centre of the cult was a solemn ceremonial rite, for which the votaries had to make due preparation by some sort of purification, 


\section{The Christ of Faith}

and in which they were to be initiated into personal communion with the God-a Saviour God; in some cases a God who was conceived to have died and risen again to life-and by this initiation into communion or union with the God were to be assured (in the phraseology of Mithraism) of being renatus in aeternum. Further, these mystery religions, unlike Stoicism, fostered the grouping of their votaries into social clubs, in which the individual found the heartening of comradeship. Thus a mystery religion stood for personal religion, for social religion, and for inter-national religion, or at least for religion which took little account of racial and national differences.

As to the equipment with which the Christians approached the peoples of the Græco-Roman world, it is important to keep steadily in view not only their ethical and religious ideals, but also the Christian Society and the new life by which its members were inspired. It was mainly through the Christian community existing in a city that interest in Christianity was stirred amongst the citizens, and it was mainly through what they came to know of the life of the members of the community that they were attracted by the new religion. It was by life that life was quickened.

If we put ourselves at the view-point of spectators taking notice of the Christian community in 


\section{The Fact and Legitimacy of Development}

their midst, we may conjecture by what features of its life they were impressed. The Christians were evidently a true brotherhood. They made no distinctions of race or class : Barbarian and Greek, slave and freeman, unlearned and learned, were all made at home in the community. They were singularly ready to help one another in the hour of trouble. Mild and inoffensive they might be, but they could rise to exceptional heights of endurance and heroism. They had a strange way of meeting insult and injury with acts of kindness to the wrongdoer. They made much of chastity; they were severe in their condemnation of whatever threatened the sanctity of the life of the home; they shut the door of their Society against evil-livers. Further, in an age when men fell readily into despair about themselves and about the world in general they had " morning hearts and morning faces"; they worked, endured and suffered as if they believed that "the best is yet to be." And the note of joy was as marked in their life as that of hope. They might be poorly furnished with this world's goods, they might be looked down upon by more prosperous neighbours, they might have more than an average share of heartaches, they might have to suffer, even to die for their religion, but, in spite of all, they seemed to have found the secret of a gladness, of which nothing could rob them. Of course these choice features of the life of the Christian 


\section{The Christ of Faith}

community were crossed by less worthy features in the life of some of its members, but there were these choice features for sympathetic spectators to notice, and to be impressed by.

If a sympathetic spectator came into closer personal contact with the Christian community, he would learn where its attractive life had its source. The Christians, he would discover, were drawn together into their closely knit fellowship by devotion to a common Lord, one called Jesus, who had lived a wonderful life, who was put to death on a Cross, and who rose again to be ever present with His disciples. They were familiar, through oral tradition or written documents, with reminiscences of His life and teaching, which were a constant subject for meditation, when they met together in assembly, and of which they were ready to talk with outsiders. They were continually brooding over the words of the Lord Jesus and the story of His life and passion, for there they found the ideals for their way of thinking and for their way of living. Nor was the Lord Jesus conceived as belonging only to the distant past ; He seemed to be still present with them in spirit. His presence was at the heart of their social worship, and at the heart of the daily life of the individual members. Loyalty to Jesus as Lord was the secret of the life of the Christian community - of those choice features of its life, by which the outsider was impressed. 


\section{The Fact and Legitimacy of Development}

Through the fuller understanding of the significance of the Christian community, which a sympathetic spectator might thus acquire by closer personal contact, he might be drawn on to long for admission to its membership, in order to share in its life of faith and hope and love. That longing would meet with a warm response from the community. After instruction as to what membership of the Christian Society involved, and with the fixed resolution to acknowledge Jesus as Lord, he would be received by baptism into the Christian Society, through whose fellowship the new life quickened in his heart would be continually strengthened and enriched.

The Christians, then, approached the peoples of the Græco-Roman world, as communities or brotherhoods closely knit together and inspired by " the spirit of life in Christ Jesus." They had lofty ethical ideals, and lofty thoughts of God and man and the world, but they were more than ethical and philosophical teachers, such as the Stoic preachers and missionaries. They were, above all, members of a Society which had a distinctive life, in which their lofty ideals and thoughts were lived out. This distinctive life of theirs was the main thing. Their theology was the intellectual expression of the faith by which they lived; their organisation, fluid and varying as it may have been, was an instrument for fostering and propagating the new life of which they 


\section{The Christ of Faith}

had had a personal experience. It was by their Christ-life, not merely by their ethical and theological teaching, or by their organisation, that they were the salt of the earth, the light of the world, the leaven for leavening the whole lump.

The central feature, then, of the Christian move7 ment was the Christ-inspired life of the Christian Society. Therein lay not only the justification, but also the necessity for development. As has been justly said, no founder of a religion has left more for His followers to do than Jesus. He provided His followers with no such system of doctrine, no such plan of church government, no such directory of public worship as we find in the subsequent centuries. His was a greater gift. He came that men " might have life and have it abundantly" (John x. IO). The Christ-inspired life was not something static, given once for all, but something dynamic which could only fully reveal itself in its growth. "To live is to change ; to be perfect is to have changed often." So, as the Giver of life, Jesus laid upon the Twelve and their fellow disciples, and through them upon the Christian Society of subsequent ages an immense responsibility for living out this life in changing circumstances and new environments.

Development, therefore, may be the evidence of vigorous life. A mustard seed reveals its vitality

I Newman, Essay on Development, p. 39. 


\section{The Fact and Legitimacy of Development}

by its power of not only affecting its environment but also of assimilating elements from it. Vitality involves assimilating power. If, then, the Christian Society, in contact with the environment of the Græco-Roman world, laid hold of worthy elements in its philosophy and pressed them into its own service ; if it laid itself alongside the nobler aspirations in its religious life, and even to some extent made use of its language and observances; if it adapted its own organisation to changing conditions and was influenced in these adaptations by forms of organisation existing in its environment, such a process of development was not necessarily a corruption. It may have been a proof of the strength and fulness of the Christinspired life.

Both of the fact and of the legitimacy of a large development since the apostolic age, there is a franker recognition to-day than was usual half a century ago. For this, many reasons may be assigned. Something is due to the greater readiness to regard the outstanding note of primitive Christianity as the wealth and warmth of its Christ-inspired life, and something is due to the hold which the conception of evolution has gained on the popular mind. This other factor has also to be taken into account, that the historical investigation of the early Christian centuries is tending to-day to accumulate evidence for a far greater development of theological doctrine 


\section{The Christ of Faith}

and ecclesiastical organisation after the apostolic age than had usually been allowed for.

A strong impetus to the franker recognition of development was given from an unexpected quarter. In his famous "Essay on the Development of Christian Doctrine," published in 1845, Newman explained how he was being forced from his old moorings in the Anglican Church towards the haven of the Church of Rome. In the years when he was the antagonist, often the trenchant antagonist, of the Church of Rome, he was familiar with the argument that in the course of its history after the schism between the Western and Eastern Churches it had introduced many doctrines and usages which were unknown in the earlier centuries-the centuries which he himself as a Tractarian held in special veneration as vouching for the doctrine, ministry and rites, which, in his belief, were indispensable for any genuine form of Christianity. This development in the Church of Rome was fully in his view, when in the years before 1845 he was tending Romewards. But what, he asked himself, if a similar development had taken place in the earlier centuries; if the development in the Church of Rome in the later centuries was but a continuation of a process that had been going on ever since the second century, that is through those earlier centuries, to which he and his fellow-Tractarians had been pinning their faith? So, for example, he now 


\section{The Fact and Legitimacy of Development}

argued against the Tractarians, or rather against his earlier self, that there was development in the doctrine of the Trinity; that from some of the accredited Fathers of the church less material could be found in support of the Nicene doctrine of the Trinity than in support of the doctrine of purgatory. From his wide knowledge of the Fathers he adduced many other illustrations of a continuous process of development in matters which, he had previously believed, had been definitely and once for all decided by Christ and His apostles and delivered to the guardianship of the church. Why, then, he asked, should such development be legitimate up to a certain date in the history of the church, and illegitimate ever after ? Was the Church of Rome by its subsequent developments not proving itself to be the true successor of "the undivided church," so greatly venerated by the Tractarians? If the beliefs and institutions of "the undivided church" were not explicitly sanctioned by Christ and His apostles, but were arrived at by a process of development, similar to that by which the Roman Catholic Church in its separate existence arrived at its distinctive features, what ground was there for the assumption of the Tractarians that the only authoritative guidance in Christian doctrine and worship and in ecclesiastical government was to be found in "the undivided church" of the early centuries? 


\section{The Christ of Faith}

Newman's recognition of so large a measure of development in the early church startled Tractarians ; it startled many who had no sym pathy with Tractarianism, it startled those who believed that at least the theological doctrines which were dear to them were exactly what had been delivered to the church by Christ and His apostles. It was also startling for the church, to which Newman had transferred his allegiance. The Church of Rome has not been eager to acknowledge development. It has tended rather to claim that the changes which have taken place in her doctrine and worship have the sanction of unwritten tradition, which goes back to the apostles, and of which she has been the faithful custodian and steward. Still, Newman's theory of development, if not welcomed, has not been repudiated, however severe may have been the condemnation of Catholic Modernists, who have worked out, more consistently than Newman himself, some of the leading ideas of his Essay. However it may be in the Church of Rome, it is at any rate true of English-speaking Protestant churches that Newman's Essay has been a powerful factor in fostering a franker recognition of the idea of development in the doctrinal beliefs, organisation and worship of the Christian Society.

But change is not necessarily a sign of life; it may be a sign, not of growth, but of degeneration. In the course of the development of the Christian 


\section{The Fact and Legitimacy of Development}

Society there was at least the risk of aberrations from the ideals of the apostolic age. When the Christian Society came into close contact with the environment of the Græco-Roman world, and assimilated some of its worthier features, there was the possibility of the environment subtly affecting the Christian religion in harmful ways. The Christian Society of the second century was keenly conscious of the danger to which it was exposed from close contact with the religious philosophy of the Greeks, which at this period was profoundly influenced by various Oriental speculations. It had to carry on a severe and long-drawn-out conflict with Gnosticism -a conflict which is largely responsible for the expression of the Christian faith we have in the so-called Apostles' Creed. It triumphed over Gnosticism, but we have to reckon with the possibility of it becoming itself infected with theologising peculiarities, which were in many ways alien to the genius of the apostolic age. There was also a danger for the Christian Society in coming into close contact with popular cults, like those of the mystery religions. It might be highly praiseworthy to try to understand the nobler features of these cults, and to convince their votaries that what they were seeking they would find more surely in the religion of those who acknowledged Jesus as Lord. But there was the possibility that in thus laying itself alongside of these cults, and in adapting its 


\section{The Christ of Faith}

message to their votaries, the Christian Society would be unconsciously infected by ideas, which belonged rather to religions over which it had gained the victory than to the religion of the apostolic age.

The risks of aberration were increased after the second and third centuries. As long as the Christian Society had to struggle for existence against powerful vested interests and wild outbursts of the hostility of the populace, and was continually menaced by organised persecution on the part of the imperial government, that is, as long as it cost something to be a Christian, there was a measure of security for the maintenance of high ideals of Christian life and thought. But the day came, in the beginning of the fourth century, when it rather cost something not to be a Christian. After the "conversion" of Constantine and the virtual recognition of Christianity as the religion of the empire, the way was opened for further possible aberrations. The more Christianity became the fashionable religion, the greater was the danger of the Christian Society gaining recruits from those who were not inspired by the highest motives, and the greater was the danger of the ideals of the Christian Society itself being thus lowered.

In various quarters, then, there were risks of aberration in the development of the Christian Society. It does not follow, of course, that because the risks existed aberration took place. It may be 


\section{The Fact and Legitimacy of Development}

pleaded that against these risks the Christ-life of the Society was powerful enough to put up a brave and successful fight. But the risks were there, and they have to be taken into the reckoning when the development of Christian doctrine and worship is under consideration. 


\section{CHAPTER XII}

\section{Loyalty to the Ideals of Jesus a Test of Legitimate Development}

IF the gift of Jesus is life-His own life-the Christian Society is charged with the responsibility of developing this Christ-inspired life in many directions. Its responsibility is not duly discharged, if it merely cling to the forms which the development assumed in the apostolic age. But in regard to changing forms a necessary condition of a legitimate development may be assumed to be loyalty to the ideals of Jesus.

In the four following chapters we shall consider whether developments in connection with the unique place assigned to Jesus, and with the emphasis laid upon the Christian Society itself, conform to this test.

In other three chapters we shall apply this test to developments in connection with Christian worship, the Christian ministry and Christian doctrine, which have given rise to misgivings.

In regard to these last-mentioned developments we are confronted with a way of thinking which 


\section{Loyalty to the Ideals of Jesus}

leads those who espouse it to assume that there is no adequate reason for raising the question whether they are in conformity with the ideals of Jesus. Their legitimacy is held to be so indisputable as to be withdrawn even from examination.

This way of thinking calls for consideration in the present chapter. It is thus described by Principal Rainy: "Everything in Christianity was divine, it came from divine revelation, and was animated by divine life. The church, therefore, which is the completest earthly embodiment of Christianity, must eminently be divine. It included much human weakness and inconsistency; but its institutions and its life were from on high. Hence a very visible tendency prevails to hold every institution and observance, which at any time found acceptance in the Church, as something divine, original, apostolic." Canon Mozley's description is of similar import: "Whatever is, is right. The fact of certain ideas getting established becomes itself the proof of their truth.",

It is in the Roman Catholic Church that this tendency has had its fullest manifestation. The assumption is made and acted on, that whatever has found deliberate acceptance by the church from the second century to the twentieth has divine sanction; that whatever has been decreed by œcumenical

I The Ancient Catbolic Cburch, p. 72.

${ }^{2} \tau$ be $T$ beory of Development, p. 118. 


\section{The Christ of Faith}

Councils (and since 1870 , by the Pope speaking ex cathedra) regarding Christian doctrine and the uses to which it is to be put, regarding the ministry and government of the church, regarding the sacraments and such other means of fostering devotional life as the cultus of Mary and the saints, is what Christ and His apostles intended to be done. As to minorities who were opposed to what was decreed by a Council, and as to "schismatic" Christians such as the Montanists, Donatists, and in later times the Protestants, who withdrew or were driven from the Great Church, they were the champions of ideas and practices which, just because they were condemned by the Great Church, were thereby actually condemned by Christ and His Apostles. Outside the Great Church there could be no genuine form of Christianity-no Christianity according to Christ and His Apostles.

The Thirty-nine Articles say of General Councils that "for as much as they be an assembly of men, whereof all be not governed with the spirit and word of God, they may err and sometimes have erred, even in things pertaining unto God." But a considerable number of Anglican churchmen seem to regard the great Councils of "the undivided church," or at least the first five or six of these, as not only worthy of reverent regard, but as authoritative in matters of doctrine for all subsequent ages. They seem also to regard as authoritative for all 


\section{Loyalty to the Ideals of Jesus}

subsequent ages the principles which the church of the first centuries worked out in connection with the Christian ministry and sacraments. In these matters we are not only to learn from the early church, but to be bound by it-so bound by it, that if we are outside the fellowship of a church which accepts its creed and ministry and sacramental principles, we are outside the covenant of God's guaranteed grace.

In other branches of the Christian Church, where there is a disposition to question the validity of some of the views held by the early church as to the significance of the Christian ministry and sacraments, there is a tendency to regard its main doctrinal decisions, not only as possibly the best that could have been reached in the circumstances, but as final and authoritative, and to regard as doubtfully Christian those who raise difficulties about these decisions. In this sphere, what the church has done is supposed to have divine sanction.

Whether the field in which the tendency to regard what the church has done in the past as final and authoritative, is a wide one as in the Roman Catholic Church, or narrower and not always clearly defined as with "Catholic" Anglican, or Lutheran and Calvinistic theologians, it is taken for granted that what is accepted as final and authoritative has behind it the authority of Christ and His apostles. 


\section{The Christ of Faith}

If the need arises in controversy with opponents, an appeal is made to Scripture for support. The method of approach is not to seek to discover the teaching of Scripture as it discloses itself to the reverent and truth-loving Biblical student, but to find support for decisions of the church which are already accepted as final and authoritative. The Bible is so varied a literature that more or less plausible support can be found in it for doctrines and usages, on which the church, Roman Catholic or Reformed, has put its deliberate imprimatur. It is this method of handling the Bible-not to find out the real meaning of the language of the biblical writers, but to press their language into the support of already accepted conclusions-which gives point to the words of a Calvinist divine, quoted by Sir William Hamilton : ${ }^{\mathrm{T}}$

Hic liber est in quo quaerit sua dogmata quisque;

Invenit et pariter dogmata quisque sua.

The Roman Catholic Church invokes the authority of Scripture for all its accepted doctrines and institutions. For the primacy of the Bishop of Rome in Christendom, and for the papal infallibility decreed by the Vatican Council, it appeals to the words of our Lord to the disciple who made the great confession at Cæsarea Philippi: "Thou art Peter and upon this rock I will build my church"

I Lectures on Metaphysics, I, p. 267. 


\section{Loyalty to the Ideals of Jesus}

(Matt. xvi. 18). For the doctrine of purgatory Newman $^{x}$ appeals to the statement in Scripture "that we must through much tribulation enter into the Kingdom of God" (Acts xiv. 22). He is aware that the question of purgatory may not have been explicitly in the mind of Paul and Barnabas, but he shares the disinclination of the Roman Catholic Church " to confine themselves to the mere literal interpretation of Scripture." "Her most subtle and powerful method of proof, whether in ancient or modern times, is the mystical sense, which is so frequently used in doctrinal controversy as on many occasions to supersede any other . . . The school of Antioch, which adopted the literal interpretation [of Scripture] was the very metropolis of heresy. . . . It may almost be laid down as an historical fact, that the mystical interpretation and orthodoxy will stand or fall together."

Some of the "Catholic" Anglicans make use of a formula which indicates how they handle Scripture as a support for their doctrinal and ecclesiastical views- "The Church to teach, the Bible to prove." Their starting point is the Creeds, the form of Church government, the sacramental system, as these were developed in the early centuries. Scripture is then appealed to for proofs of their validity, and proofs, more or less solid, are

I Essay on Development, p. 421.

${ }^{2}$ Ibid., pp. 323-4. 


\section{The Christ of Faith}

to be found there. For the purpose in view it is not necessary, it is not convenient to take into account elements in the teaching of Scripture, which seem, at least to many competent biblical students, to point in a contrary direction.

Many, to whom the distinctive views of "Catholic" Anglicans about the Christian ministry and sacraments are uncongenial, are disposed to accept the decisions of early Church Councils on Christian doctrine as final and authoritative. Here also the starting point in the use of Scripture is the historic creeds. Scripture is appealed to for support, and such support is not lacking. But it seems to many competent biblical students that here also there are elements in the teaching of Scripture which are apt to be overlooked. For example, support for the decisions of the Councils of Nicæa (425 A.D.) and Chalcedon (45I A.D.), regarding the Person of Christ can be found in Scripture, but the study of the New Testament is increasingly suggesting that there was not one uniform Christology in the apostolic age. "Though there is one faith, there is not one Christology . . . [St. Paul's Christology] is not identical with that of Peter or John, or so far as we can discern it, with that of Matthew or Luke; just as little as it is identical with that of the Nicene Creed." I

I Denney, Fesus and the Gospel, pp. 395-6. 


\section{Loyalty to the Ideals of Jesus}

But it is significant that in justification of such developments there is so little appeal to the regnant ideals of Jesus. The authority of Jesus is, of course, recognised, and is appealed to as the ultimate warrant for the developments. Jesus, it is argued, conveyed to His apostles, and through them to the episcopate, secret instructions, which covered the developments recognised by the Church. Or, as it argued in other quarters, the promise by Jesus of the Spirit to guide His disciples into all truth covered the decisions arrived at by the earlier œcumenical Councils. But if the authority of Jesus is appealed to in this general sense, there is less evidence of a resolute effort to relate these developments to the ideals of Jesus.

Newman, for example, in his Essay on Development-a volume of 453 pages-has occasion to take a survey of the development of Christianity through the centuries. We should expect to find here a more or less full reference to the source from which the whole development took its rise. But the author has scarcely a word to say about the Jesus of history - His personality, life and teaching. For one reason or another he finds it unnecessary to go so far back as the origin of the whole development, and to inquire how far the development is true to the ideals of Jesus." His essay gives us " a theory of growth

I What weight Newman attached to the ideals of Jesus may be partly judged from a reference to the Society of Friends, quoted by Principal Fairbairn from Via Media II, pp. 29-30: "There is a wel-known sect which rejects both 


\section{The Christ of Faith}

without a seed-a development without an exordium." Why did he decline to set forth his understanding of the exordium ?

There is, however, one reference to the exordium, a curious reference. "It is indeed sometimes said that the stream is clearest near the spring. Whatever use may fairly be made of this image, it does not apply to the history of a philosophy or sect, which, on the contrary, is more equable, and purer, and stronger, when its bed has become deep, and broad, and full." 2 Such language, however indulgently we interpret it, does not suggest a passionate desire to test the process of development in the church by the ideals of Jesus. If the stream is " purer and stronger," need we be ever going back to the spring ? 3

This hesitancy about going back to the spring from which the stream of Christianity is acknowledged to have flowed has been manifested elsewhere as well as in the Roman Catholic Church. It is a hesitancy of which complaint is made in many quarters, where there is an uneasy feeling that the Christ, enshrined in some of the accepted usages

Baptism and the Lord's Supper. A Churchman must believe its members to be altogether external to the fold of Christ. Whatever benevolent work they may be able to show, still, if we receive the Church doctrine concerning the ineans generally necessary to salvation, we must consider such persons to be mere heathens, except in knowledge."

${ }^{1}$ Mozley, Tbe Tbeory of Development, p. 223.

2 Essay on Development, p. $3^{8 .}$

3 Loisy has carried out to its logical conclusion Newman's contrast between the stream and its source. 


\section{Loyalty to the Ideals of Jesus}

of the Church, even in some of the "final and authoritative" decisions of the church, has somehow lost touch with the Jesus, the story of whose life and teaching we have in the Gospels. There may be, in point of time, one continuous line of succession which links the church of to-day with its Founder, and it may be difficult to specify when and how in the process of development changes which seem to be aberrations took place. That the change has been gradual, almost imperceptible at any given point, constitutes no guarantee that it has not taken place.

In presence of questions which are being raised to-day with ever-increasing urgency, a special call is made to those on whom there rests responsibility, to make clear how the decisions about Christian worship, the Christian ministry and Christian doctrine, arrived at by œcumenical councils or embodied in Confessions of Faith are related to the regnant ideals of Jesus. 


\section{CHAPTER XIII}

\section{Devotion to Jesus}

IN the apostolic age the acknowledgment of Jesus as Lord was the fundamental characteristic of the members of the Christian Society. They had an organisation and a ministry, and they had ways of giving doctrinal expression to their Christ-inspired experience. But these were not the things in which their interest was centred; they were at best but helps to foster devotion to their Lord.

In the subsequent development, it may be true that devotion to Jesus, as the essential mark of a Christian, came to have often a less commanding place, but it has never ceased to have, if not its due place, at least a large place. The personality of Jesus was linked so closely and in so many different ways with the varied life of the Christian Society, that it could never for long, or by a whole group of professing Christians, be kept in the background.

In illustration of the place which has been given in the Christian Society to the personality of Jesus, it may suffice to refer to a few facts, which disclose themselves on the surface of the story of the 


\section{Devotion to Jesus}

development of Christianity. They are selected, because they are familiar-so obvious, indeed, that their significance for our present purpose is apt to be overlooked.

I. The two chief religious rites.

By baptism entrance was gained into the membership of the Christian Society. It seems that at first baptism was " into the name of the Lord Jesus." When the fuller formula, "into the name of the Father, and of the Son, and of the Holy Ghost" was adopted, it derived its significance from the earlier formula: "the name of the Lord Jesus" interpreted what was meant by "the Father" and " the Holy Ghost." We do not here raise the question whether the meaning of the baptismal rite came to be conceived in ways which marked a departure from the mind of the apostolic age. Whatever changes may have taken place, the solemn rite of initiation into the Christian Society never ceased to suggest, however feebly at times, that the baptised person dedicated himself (or in the case of infants was dedicated by the sponsors) to Jesus as the Lord of his life.

The Lord's Supper, under whatever differing forms it has been celebrated at different periods and in different sections of Christendom, has ever had assigned to it in public worship a peculiarly prominent place as a means of expressing and 


\section{The Christ of Faith}

strengthening spiritual life. ${ }^{\mathbf{x}}$ Divergent on many points have been the views as to the meaning of the Sacrament, and, in consequence, as to the appropriate ritual, but everwhere it has been recognised that in "the breaking of bread" the worthy communicant has fellowship of spirit with the spirit of Christ; that Christ is really present to the loyal heart.

2. The reminiscences of the life and sayings of Jesus.

The Christians of the first generation were not in possession of our Gospels ; for these were not yet written. But from the outset they were conversant with the story of His life and sayings, as told by eyewitnesses, or as related at second-hand by trustworthy Christians to whom eyewitnesses told it. There may have been at a very early date some such written records as Matthew and Luke made use of in the composition of the Gospels which bear their name. But it was mainly by word of mouth that the story was at first told, whether in preaching the good news to those who were not yet Christians, or in instructing those who had been drawn, or were being drawn, to the Christian Society. Either by written records or by oral traditions the Christians of the first and following generations were not only familiar Army.

I There are a few exceptions, such as the Society of Friends and the Salvation 


\section{Devotion to Jesus}

with the apostolic reminiscences of the life and sayings of their Lord, but treasured these as "the master light of all their seeing." St. Paul besought the elders of the church in Ephesus " to remember the words of the Lord Jesus, how he himself said, It is more blessed to give than to receive" (Acts xx. 35). We find a similar formula in the Christian writers of the sub-apostolic age: "Now the Lord Jesus said." In the rubbish mounds of Egypt there have been discovered two scraps of papyrus on which are written what purport to be sayings of Jesus, and some of which are at least in the manner of Jesus. Each of these sayings, as far as the introductions are decipherable, is introduced by the words : "Jesus says" - an incidental testimony to the emphasis laid in those early times upon reminiscences of what "Jesus began both to do and to teach" (Acts i. I).

In the synagogue part of the service was a "lesson" read from the Old Testament. In the public worship of the Christians, as early at least as Justin Martyr (circa I4O A.D.), it was customary to read a lesson (followed by an address) from "the memoirs of the Apostles," as our gospels are spoken of by Justin. What importance was attached in subsequent centuries to this reading of the Gospels is indicated by the fact that it was usual for the congregation to stand during this part of the service, as is the custom to-day in many branches of the Church, both in the East and in the West. 


\section{The Christ of Faith}

The Christian Society kept in close touch with the reminiscences of the life and sayings of the Jesus of history.

3. The martyrdom of Christians.

In the persecution of the Christians by the Roman government the main charge brought against them was that they dared to avow that loyalty to Jesus their Lord had a higher claim upon them than loyalty to the Empire. At their trial before the representatives of the imperial authority their acquittal depended on their readiness to perform some simple ritual act, involving worship of the Emperor and of the gods recognised by the Emperor. Polycarp, on his way to be tried before the proconsul (I 55 A.D.), was urged by well-meaning officials to acknowledge Cæsar as Lord: "What harm could be done by throwing on the altar a few grains of incense ?" At his trial, "Swear," said the proconsul, " and I will set thee free. Revile Christ." "Eighty and six years," said the aged Christian, "have I served Him, and He hath done me no wrong. How then can I speak evil of my King, who saved me ?"

The story of Christian martyrs under the Empire reveals what a central place devotion to Jesus had in the Christianity of those days. To the Roman government the distinctive mark of a Christian was not membership of a novel religious organisation- 


\section{Devotion to Jesus}

for the Empire tolerated almost every sort of novel religious organisation - but loyalty to Jesus as the supreme Lord. It was for this martyrs were put on trial; it was for this they were willing to die.

4. Theological controversy about the Person of Christ.

In the fourth and fifth centuries the theologians were greatly exercised with the problem of so defining the person of Christ as to do justice both to His divinity and to His humanity. It was a problem on which the attention of the early œcumenical councils was concentrated. Controversy was long drawn out and often conducted with great bitterness. The language which the combatants thought fit to use in speaking of their opponents suggests that in their zeal for what they believed to be correct theological doctrine about their Lord they had forgotten for a moment their Lord's precepts about the tempers He looked for in His followers. If the conclusions reached by the councils were infallible, they were reached by the help of those who were fallible enough in their loyalty to the spirit of Christ. But behind all that shady side of the controversy there was the intense interest of the Christian Society in the personality of Jesus, in whom their Christian experience was centred. But for that interest among the great body of the common Christian people, the controversies of the theologians 


\section{The Christ of Faith}

about the person of Christ would never have been raised and kept alive.

\section{The Christian Year.}

The observance of the Christian Year, though it cannot well be traced back to the apostolic age, has been recognised in all parts of Christendom as a legitimate development-a development, that is, in harmony with the spirit of Christ. Even where there has been a luxuriant growth in the number of personalities and events included in the ecclesiastical calendar, the central feature, and that which gives its significance to everything else, is the commemoration of the life of Jesus : the outstanding Church festivals are Christmas, Good Friday and Easter. The place which the annual commemoration of the birth, death and resurrection of Jesus has held in the thought of Christians is an indication that a mere " theological "Christ has not taken the place of the historical Jesus in Christian devotion.

\section{Christian Hymnody.}

In Pliny's letter to Trajan (I I I A.D.), asking the advice of the Emperor as to how persons accused of being Christians were to be treated, he tells what he had found out about the Christians by an investigation which was evidently painstaking. Amongst other facts of exceptional interest, he mentions that "it was their habit on a fixed day to assemble 


\section{Devotion to Jesus}

before daylight, and sing by turns a hymn to Christ as a god (carmen Christo quasi deo)." From the apostolic age, through all the centuries and in every part of Christendom, hymn-singing has been a perennial feature of Christian worship; and as in the days of Pliny, so always, Christian hymnody has centred in Christ. In estimating the significance of this feature of Christian hymnody, it is fitting to take account of the obvious fact that the hymns of Christendom have not been the work of councils or ecclesiastical committees, that they have welled up out of the Christian experience of individuals, and have won the approval of others by the strength of their appeal to a common Christian experience.

\section{Christian Art.}

In the first centuries " art for art's sake" did not appeal to the Christian Society. It seems as if, less sensitive to the beauty of God's world than their Master, they were less willing to serve themselves heirs to the heritage of Greece in this sphere than in that of religious philosophy: the association of ancient art with the worship of the gods and goddesses of polytheistic religions had something to do with this attitude of aloofness. At first Christian art was on the same plane as spoken or written language - a vehicle for the expression of Christian thought. The artist, who drew on a wall 


\section{The Christ of Faith}

of the Catacombs a rude figure of a shepherd with a lamb round his neck, was chiefly concerned with telling out to himself and to others something of his Christian experience. For many centuries the wall paintings, mosaics, stained glass windows and sculptures, with which churches were adorned, were meant, as much as the words of the preacher or the singing of Christian songs, to be helps for Christian devotion. So we find advice given by St. Nilus in the fifth century "to fill the holy sanctuary on both sides with histories of the Old and New Testaments by the hand of a skilful artist, in order that those who were unable to read the divine scriptures may, by looking at the painting, call to mind the courage of men who have served the true God, and be stirred to emulation by their heroic deeds." In the Middle Ages, both in the East and the West, art was increasingly pressed into the service of Christianity, and not always in wholesome directions. But what is prominent in all this artistic activity, expended not only upon churches, but upon books, ivories and similar things for the use of individuals, is the life of Jesus. For example, a famous illustrated book, the Biblia Pauperum, ${ }^{2}$ which has come down from the Middle Ages, is a series of forty pictures of the life of Jesus (especially of the events connected with His birth and passion),

I Smith's Dictionary of Cbristian Antiquities, I, p. 816.

2 Didron, Cbristian Iconograpby, II, p. 4०3. 


\section{Devotion to Jesus}

each of which is accompanied by two pictures of scenes from the Old Testament supposed to foreshadow the event recorded in the Gospel story. The abundant use which was made of this book, and of books of a similar class, by artists in search of subjects for artistic work, in churches and other buildings, bears its own witness to the place which was held among Christian folk by the Jesus of history.

\section{A Mediæval Christian.}

St. Francis of Assisi (first quarter of the thirteenth century) had little interest in the theological and ecclesiastical questions which engrossed the Churchmen of his day. The significance of his life and influence is centred in devotion to Christ-to no mere " theological" Christ, or a Christ of pious fancy, but to the Jesus of the Gospels. What held him in the Gospel story was the love of Jesus for His fellows, revealed in His Cross and in His whole life. It was his supreme ambition to live over again the life of Jesus, not in its mere outward setting, but in its spirit; to have His standard of true values; to free himself like Jesus from thraldom to riches and comfort, to social distinction and worldly prosperity; to love his fellows and to help them, as Jesus did; to be a man of joy, like Jesus ; to rejoice in the beauty of God's world, like Jesus. He cut himself loose from the money and property which might have been his; 


\section{The Christ of Faith}

in his own picturesque phraseology, he wedded the Lady Poverty - in the interest, it is true, of his own personal life, but also that he might have a more sympathetic understanding of the common man, and be better able to help him. Moved by brotherly love for his fellows, as deep as it was wide, he went from city to city with his message and with his appeal. He was not bent on increasing the devotion of the people to the ecclesiastical organisation, or to true doctrines about Christ's person. What he was bent on was, that the people should live as Jesus lived, for there and there alone, he believed, were to be found true life and true joy. Disciples and fellowworkers-the little brothers, or as St. Francis sometimes called them, God's Merrymen-gathered round him in ever increasing numbers. In a few years the movement he had initiated had spread far beyond Italy, and affected profoundly the life of Christendom.

St. Francis was, of course, a rare Christian spirit. But his emergence in the thirteenth century cannot well be regarded as an anomaly. $\mathrm{He}$ had his links with the Christianity of that age. It was in its atmosphere he was reared and learned about the Jesus of the Gospels. That he attracted so many fellow-workers, and that their appeal and his evoked such an extraordinary response from the Christian folk of many lands, indicates that devotion to Jesus and His ideals had a larger place in the Christianity 


\section{Devotion to Jesus}

of the "dark ages" than is sometimes supposed. The definition of a Christian as "one who has fallen in love with Christ" would not have failed to awaken a responsive chord in the thirteenth century, or indeed, let us add, in any of the Christian centuries.

In regard to some aspects of such devotion to Jesus as has been noticed in the preceding pages, no question is raised as to the legitimacy of the development: a certain fervour of devotion is evoked by every great religious teacher. It is when these limits are passed that the question is raised. What is called to-day the "Jesus-cult"-that is, the assigning to Jesus in the faith and worship of the Christian Society a quite unique place-is said to go beyond what Jesus Himself contemplated, and to have been borrowed from cults, with which the followers of Jesus were brought into contact in the Græco-Roman world.

But Jesus did not regard Himself as merely a religious teacher. He was conscious of a vocation to be Leader in a Kingdom of God, which surpassed in its grandeur and universal scope any dream of the divine purpose with humanity, which the noblest spirits among Jews or Gentiles had ever cherished. As Leader in this enterprise $\mathrm{He}$ needed fellowworkers on whose absolute devotion $\mathrm{He}$ could count. Loyalty to Himself for the sake of the Kingdom 


\section{The Christ of Faith}

of God $\mathrm{He}$ demanded as a condition of discipleship. So $\mathrm{He}$ called for a devotion which would seem extravagant, if $\mathrm{He}$ were merely a religious teacher. "He that loveth father or mother more than me is not worthy of me; and he that loveth son or daughter more than me is not worthy of me. And he that doth not take his cross, and follow after me, is not worthy of me" (Matt. x. 37, 38). 


\section{CHAPTER XIV}

\section{Emphasis on Goodness of Life}

IT is sometimes alleged by those who regard the unique place assigned to Jesus by the Christian Society as a departure from the ideals of Jesus, that this "Jesus-cult" has tended to let less emphasis be laid on what Jesus the religious teacher did unquestionably put in the forefront-the sovereignty of goodness. It is true, of course, that through the Christian centuries zeal for theological interpretations of the person of Christ, and for the observance of the rites of Christian worship has often been more highly esteemed than zeal for goodness of heart and life. But that such a perversion of zeal is involved in the unique devotion of Christians to their Lord is a suggestion which is not borne out by the facts. It is to some of these facts regarding the emphasis which the Christian society has laid upon goodness of life we would call attention in this chapter.

If the converts to Christianity had been only Jews, or Gentiles who had previously been deeply 


\section{The Christ of Faith}

influenced by Judaism, the insistence by the Christian Society upon goodness of life as a condition of membership might not call for special comment. But when we consider that from the second century the majority of the converts were Gentiles, many of whom had not been accustomed to link religion and goodness so closely together as the Jews, this feature of the Christian Society in the GræcoRoman world is the more worthy of notice. The popular religions of the Gentile peoples exercised, of course, an influence of some sort on morality, but religion and morality were not conceived as being identical in their interests; they could go their own separate ways, not only diverging from, but frequently in conflict with each other. But " the new religion was itself morality, but morality consecrated and raised to a higher power than it had yet reached." I

Insistence of the Christian Society upon goodness of life attracted the notice of cultured Gentiles, who had occasion to inform themselves about the kind of people the votaries of the new religion were. In his letter to Trajan, Pliny says that "they bound themselves with an oath, not for any crime, but not to commit theft or robbery or adultery, not to break their word, and not to deny a deposit when demanded." The only faults he imputes to them are " a wicked and arrogant superstition, obstinacy

I Warde Fowler, The Religious Experience of the Roman People, p. 466. 


\section{Emphasis on Goodness of Life}

and unbending perversity"-faults in which he detected, and not altogether without reason, a menace to the supreme authority of the imperial government.

This " note" of the Christian Society, vouched for by unsympathetic observers like Pliny, finds ample attestation in early Christian writings. The Teaching (Didache) of the Twelve Apostlesa short tractate written about the beginning of the second century and discovered in $1875^{-}$-was apparently a manual of instruction for catechumens. Its first pages describe "the way of life," which is to be followed by those who have been baptised. "Now the way of life is this: first, thou shalt love God who made thee; secondly, thy neighbour as thyself, and all things whatsoever thou wouldst not should be done to thee, do thou also not do to another." In the expansion of this text we are in the atmosphere of the Sermon on the Mount. "Love ye them that hate, and ye shall not have an enemy. . . If anyone give thee a blow on the right cheek, turn to him the other also, and thou shalt be perfect. . . . Give to every one that asketh of thee, and ask not back, for the Father wills that from our own blessings we should give to all. Be not angry, for anger leadeth to murder, nor given to party-spirit, nor contentions, nor quicktempered, for from all these are generated murders. Be not a liar, nor a lover of money, nor 


\section{The Christ of Faith}

fond of vainglory. . . Be not a murmurer, for it leadeth to blasphemy. . . . Be not one that stretcheth out his hands to receive, but shutteth them close for giving. . . . Thou shalt not turn away from him that needeth, but thou shalt share all things with thy brother, and shalt not say that they are thine own, for if we are fellowsharers in that which is imperishable, how much more in perishable things? . . . Thou shalt not in thy bitterness lay commands on thy manservant or thy maidservant, who hope in the same God." The author has his doctrinal beliefs, but he has little to say about them in this manual. What he keeps before those who are looking forward to admission into the Christian Society is a "way of life," "a yoke of the Lord," such as he has sketched.

Reference may be made to another early writing, also recently discovered, and belonging probably to the first half of the second century-the Apology of Aristides, addressed to the Emperor (Hadrian ?) on behalf of the Christians. The author tells the Emperor what sort of people the Christians are, and necessarily confines himself in the circumstances to what is notoriously true. Amongst other features of their way of life he cites these : "They have His commandments graven on their hearts. . . . Whatsoever they would not should be done unto them they do not to another. $\mathrm{He}$ that hath supplieth him that hath not, without grudging; if 


\section{Emphasis on Goodness of Life}

they see a stranger they bring him under their roof, and rejoice over him, as over a brother indeed, for they call not one another after the flesh, but after the spirit. They are ready for Christ's sake to give up their own lives; for His commandments they securely keep, living holily and righteously, according as the Lord their God commanded."

These quotations indicate that the Christian Society regarded baptised persons as pledged to a life of exceptional goodness, and as no longer worthy of membership, if they failed to live up to their pledge. The tie which bound the members together was the "tie of a common ideal and a common practice." "In the midst of " a crooked and perverse generation' they could only hold their own by the extreme of circumspection. Moral purity was not so much a virtue at which they were bound to aim, as the very condition of their existence." 'The life of goodness to which they were pledged was no mere severe and cold moralism; it was aglow with great convictions about God, man's infinite worth as a child of God, and God's purpose with the children of His human family; it was aglow with the warmth of love and hope and joy. It was not merely one of many interests for the Christian Society; it was their chief interest. "Perhaps nothing strikes one more than the singular moral heat - the enthusiasm about goodness-which

I Hatch, Tbe Organization of the Early Cbristian Cburcbes, pp. 68, 69 . 


\section{The Christ of Faith}

we meet in the Christian writings. To be good is no longer a doctrine of philosophy, or a matter of taste; it is a calling, a career; a summons, as imperative as wonderful, has awakened men to it It has become for Christians their inheritance to be realised, their proper destiny to be achieved, the field on which they are to make good the reality-the glory-of the religion which has taken them captive."

In this insistence upon goodness-goodness which if, in part coinciding with, in part outstripped the ideals of the ethical teachers of the Gentile worldwe learn how the early Christians interpreted their acknowledgment of Jesus as Lord. Discipleship meant for them loyalty to the ethical ideals of the Master. Here was the root of what was ethically distinctive in their individual and social life. For example, the early Christians were recognised, even by those whowere hostile to Christianity, as extraordinarily ready to be helpful to fellow Christians in distress-the poor, widows and orphans, the unemployed, the victims of pestilence, prisoners and those condemned to the mines. And the source of the inspiration of this social service is indicated by Harnack in the first sentences of his chapter on the subject. " 'I was an hungered, and ye gave me meat: I was thirsty and ye gave me drink: I was a stranger, and ye took me in: naked, and ye clothed me: I was

I Rainy, The Ancient Catbolic Cburch, pp. 67, 68. 


\section{Emphasis on Goodness of Life}

sick and ye visited me: I was in prison and ye came unto me.' These words of Jesus have through many generations shone so brightly and worked so powerfully in His church that we can characterise the Christian message as also the message of love and helpful service."

Jesus had left His hearers in no uncertainty as to the sovereign place $\mathrm{He}$ gave to goodness and to goodness of an exceptional kind. He had made them aware, by His life as well as by His words, that disciples of His were expected to do " more than others." From the first the members of the Christian Society took for granted that by their acknowledgment of Jesus as Lord they were committed to aiming at exceptional attainments in the good life. They were not content with the highest standards accepted by the Gentiles amongst whom they lived ; they were inspired by a higher vision. Whatever importance the best ethical teaching of the Gentiles may have attached to purity of motive, chastity of thought, the forgiveness of wrongs, service to others, the stewardship of wealth, the Christians put a new accent on these things. This extraordinary devotion of Christians to their "way of life," if it seemed to some Gentiles a form of insanity, did not fail to make on others a different impression. Here indeed was one secret of the spread of Christianity. The

I Die Mission und Ausbreitung des Cbristentbums, pp. 105-6, Ed. I. 


\section{The Christ of Faith}

light that shone from their life drew men on to "glorify their Father which is in heaven." "The one crowning proof of the truth of the Gospel, the miracle of all miracles, was the Christian life and the Christian Society."r

But against all that, it is said by those who regard Jesus as merely a religious teacher, has to be set the wide-spread tendency of Christians, from at least the end of the third century, to cut themselves loose from the interests and duties of social life. Renunciation was here the watchword, and renunciation which is not an ally of goodness, so far as goodness is conceived as love-inspired service to the common weal. But is such renunciation involved in the unique devotion to Jesus, to which exception is taken ? is it not renunciation of another kind ?

Unique devotion to Jesus does involve renunciation, but renunciation for the sake of the interests of the Kingdom of God. Readiness for this kind of renunciation was a mark of discipleship, and opportunities for its exercise were abundant in the second and third centuries. The Christian Society was during that period tested and sifted by active hostility from various quarters-from those who believed in the gods of the popular religions, and those whose interests were bound up with the

I Bigg, The Cbristian Platonists, p. 264. 


\section{Emphasis on Goodness of Life}

maintenance of their worship ; from the less reputable section of the populace, who resented the advent of the strait-laced fanatics, given to scowling at many of their amusements and pursuits; from the representatives of the imperial government, who scented danger in the growth of a society, which dared to avow allegiance to an authority superior to that of the State. In such circumstances the Christians had ample opportunities for the heroic self-sacrifice of which Jesus had so often spoken as inevitable for those who would be His disciples. One of the characteristic features of the Christianity of those early centuries was the readiness of so many of its members to suffer martyrdom for the sake of Jesus and His ideals; in some cases their positive joy in the prospect of martyrdom. "Now," said Ignatius on his journey from Antioch to the amphitheatre at Rome, "now I begin to be a disciple" -rejoicing in the opportunity that has at last come to him of expressing worthily his interpretation of the genius of the Christian life.

At the close of the third century renunciation was beginning to be interpreted in a new way-not as a means of rendering exceptional service to the Kingdom of God, but as withdrawal from the sphere of common life and duty for the sake of the interests of the religious life of the individual. This monastic ideal of the "perfect" life had extraordinary attraction for earnest Christians who were eager to 


\section{The Christ of Faith}

find outlet for their sacrificial ardour, and could no longer find it where the heroes and martyrs of the times of persecution had found outlet for theirs.

But the monastic ideal of the Christian life was not the outcome of unique devotion to Jesus. The new movement was shaped by other modes of thought than those of the first generations of Christians-modes of thought which can be traced to the environment of the Græco-Roman world.

In the first place, there was a wide-spread tendency among serious-minded people to regard the world as incurably evil. The spirit of man, so it was believed, belonged to a divine sphere, but in the period of its earthly existence found itself in an alien sphere; in a prison house in which it was impossible to live a truly spiritual life. The best it could do was to cut itself loose, as far as possible, from earthly ties. Freedom from the finite and its interests opened up the only path to the infinite, to life in God.

In the second place, the ethical ideals of Stoicism exercised a strong influence, especially upon the more educated classes. One special feature of Stoicism was the emphasis it laid upon the individual soul. Be a man's outward circumstances what they may, so the Stoics preached, let him fall back upon himself, upon his native dignity and strength; let him care above all for his own inward self, its independence, its self- 


\section{Emphasis on Goodness of Life}

sufficiency, its latent wealth. The Stoics were not indifferent to social duty; on the contrary, they contributed fruitfully to the development of higher social and political ideals in the Roman Empire, but it was individual "salvation" they kept in the forefront.

By these and similar modes of thought the monastic ideal of the "perfect" Christian was largely shaped. The ties and interests of common life, so it was implied, did not open up the best pathway to life in God. Rather were they hindrances. The more they could be renounced, the greater was the chance of becoming a "perfect" Christian. And along with this disparagement of common life, as affording at best an imperfect pathway to life in God, there went, especially in the earlier stages of the monastic movement, a conviction that in solitude the individual Christian had the surest path for finding God and securing the salvation of his own soul. Such an ideal of the " perfect " Christian could not well be rigidly adhered to ; it underwent various compromising modifications; but the ideal was an effective force in the various forms which monasticism assumed in the course of its history, and an effective force outside, as well as inside the monastic communities.

The monastic ideal, however we may explain its emergence in the Christian Society, cannot be brought into harmony with the ideals of Jesus as 


\section{The Christ of Faith}

embodied in His life and teaching. To Jesus the world is not incurably evil; it is no prison house for the spirit of man ; it is His Father's world, in which $\mathrm{He}$ finds His Father's presence and His Father's goodness. He finds His Father, too, in the common life of man, which $\mathrm{He}$ shares. He neither Himself takes flight from it, nor suggests such flight for His disciples. If $\mathrm{He}$ calls for renunciation, it is for the sake of His great enterprise, the Kingdom of Godnot as the means of achieving individual salvation. No one, in His eyes, can be a perfect Christian, who takes flight from the responsibilities, the problems, the vexations, the crosses of that common life in which love like His own-the supreme ideal for the perfect Christian-has the best chance of expressing itself. Nor can he be a perfect Christian who cares more for his individual spiritual self, than for the interests of that Kingdom of God for which Jesus calls upon His disciples to labour in comradeship with one another.

But while unique devotion to Jesus cannot be charged with responsibility for the wide-spread tendency, manifested in Christendom since the end of the third century, to renounce social duty and service professedly for "Christ's sake," let it be acknowledged that the monastic movement has been a witness to the demand of Jesus that His followers "do more than others." It may have gone astray in interpreting what this "more" is, 


\section{Emphasis on Goodness of Life}

but in assuming that the average goodness of the virtuous citizen is not the standard for the life of Christian discipleship it has been more loyal to the ideals of Jesus than some of its critics.

And, let it be added, loyalty to Jesus and His ideals modified in many directions the monastic ideal, especially in Western Christendom. There was no complete withdrawal from social life, or renunciation of interest in the common weal. The monasteries were brotherhoods, whose members ministered to those who were in distress, and did noble work for education, and for the advancement of civilisation in other spheres. The monks were for many centuries the foremost Christian missionaries. As has been justly said, they were "the spearhead of the host." In St. Francis we see how far a mediæval monk could transcend the monastic ideal of Eastern Christendom in the fourth century. For him, God's world was no prison house ; it was full of beauty and gladness. $\mathrm{He}$ was under no temptation to withdraw from his fellows that he might draw nearer to God. Inspired by a love too strong for the intrusion of the thought of self, he went amongst them, and for their sake joyfully accepted hardships and renunciation. If he renounced all that he had, it was that he might be a fellow-worker with Jesus for the Kingdom of God. 


\section{CHAPTER XVI}

\section{God Conceived and Worshipped as God in Christ}

In the apostolic age the God with whom Christians are aware they have to do is God as $\mathrm{He}$ has been revealed in Jesus. This conception of God as God in Christ is a prominent feature of historical Christianity, in its ethical as well as its religious life. It is interesting to find unsympathetic observers taking note that the God worshipped by the Christians was somehow identified with Jesus. "It was their habit," so Pliny reported to the Emperor Trajan, " on a fixed day to assemble before daylight, and sing by turns a hymn to Christ as a god." "If," said Celsus, towards the end of the second century, " these people worshipped one god alone, and no other, they would perhaps have some valid argument against the worship of others. But they pay excessive reverence to one who has but lately appeared among men and they think it no offence against God, if they worship also His servant."' That this conception of the Christian's God was familiar to

I Origen, Against Celsus, viii. I 2. 


\section{God Conceived and Worshipped}

the unfriendly populace is confirmed by the discovery seventy years ago of a rough drawing on a wall of one of the rooms on the Palatine in Rome-now removed to the Museo Kircheriano. It is meant to be a caricature of the Christian religion at the beginning of the third century. A man with the head of an ass is outstretched on a cross, and a figure, intended to be taken as a Christian, is represented in the attitude of adoration. Scribbled underneath in rude lettering are these words (in Greek) : "Alexamenos worships God."

It is scarcely necessary to adduce from early Christian writers evidence that God for the Christians was God in Christ. Two quotations, however, may be given. "We say, and we say openly," writes Tertullian, " and while ye torture us, mangled and gory we cry out : "We worship God through Christ." " "We worship," writes Origen, "one God, the Father and the Son. . . . So entirely are they one, that he who has seen the Son, "who is the brightness of God's glory, and the express image of His person,' has seen in him who is the image of God, God Himself.",

But it is in connection with controversies within the Christian Society that the importance attached in the early centuries to the conception of God as God in Christ comes most conspicuously before us.

$$
\text { I Apology, I, } 2 \text { I. }
$$$$
2 \text { Against Celsus, VIII, } 12 .
$$ 


\section{The Christ of Faith}

These controversies were occasioned by the efforts of Christian thinkers to relate Christianity to the Greek philosophy of their day. A vital question was involved in the discussions of the theologians-whether in the Christian Society God was to be conceived as God revealed in Jesus. The form in which the question was put and argued was determined by modes of thought current in some of the philosophical schools with which Christian thinkers were brought into contact.

In their intellectual search for the unity underlying and explaining the bewildering plurality of the phenomena of the world the philosophers with whom we are here concerned found the ultimate reality -that is, God-in rò ö $v$, the Existent. Of this reality nothing more can be legitimately said than that it exists : to say more would be to deny its absoluteness, its freedom from relation to anything outside itself.

But how is the gulf between God, conceived merely as the Existent, and the finite universe to be bridged ? From the Existent, Himself (or Itself) hidden, incomprehensible, unknowable, there somehow proceeded an intermediary - the Logos-who was, on the one hand, the efflux and image of the unknowable God, and, on the other hand, the ideal and the creative power of the finite universe.

Here we are in the realm of metaphysics-a metaphysical theology, which has affinity with modern 


\section{God Conceived and Worshipped}

philosophies of the Absolute, and a metaphysical cosmology, which is alien to modern modes of thought.

It was these categories of Greek metaphysics which Christian thinkers made use of to give expression to the conviction about the unique personality of their Lord, by which, in common with the whole Christian Society, they were dominated.

Controversy broke out between two theological parties as to how this conviction was to be expressed in terms of Greek metaphysics. Both parties-the party of which Arius was the outstanding figure as well as the party of which Athanasius was the outstanding figure-were agreed that Jesus was no "mere man," that as the incarnate Logos $\mathrm{He}$ belonged to the divine sphere. The question in debate was this: Is God to be conceived as merely the Existent-the hidden, unknowable ground of all things, and the incarnate Logos as a divine being created by this God ? or, in Jesus the Incarnate Logos is the true God to be found ? That is, the question was raised whether God for the Christians was the God of Greek metaphysicsthe mere Existent, or God who had been revealed in Jesus? That was a vital question, on the answer to which depended the interpretation of the meaning of the Christian religion. "The difference of a single diphthong" was the difference between

I Gibbon, Roman Empire, chapter xxi. The Athanasians were Homoousians, the Arians, Homoiousians. 


\section{The Christ of Faith}

Greek metaphysics befogging Christianity, and Christianity maintaining, in spite of the trammels of Greek metaphysics in which it had become enmeshed, the conviction that the God with whom Christians had to do was not the hidden unknowable God of philosophical speculation, but God in Christ.

The Athanasian party were ultimately victorious in the long drawn-out controversy. The Nicene Creed, which is the monument of their victory, gave expression to the conviction that for Christians God is God in Christ. The form in which this conviction was expressed has, as we shall see in chapter xix, created certain difficulties, but the conviction itself has been a dominant feature of Christianity through all the centuries.

It must be acknowledged, however, that there have been manifested within the Christian Society tendencies to conceive of God as other than God revealed in Jesus. To two of these tendencies reference may be made.

I. In connection with mysticism there has been a tendency towards a slackened hold on the conviction that God is God in Christ. For an explanation of this tendency we have to go to the environment of the Christian Society.

In the third century Neo-Platonism was a religious force amongst the educated classes of the 


\section{God Conceived and Worshipped}

Græco-Roman world, a powerful rival of Christianity. The God of Neo-Platonism was the Existent (or Absolute) of Greek metaphysics. Only, the typical Neo-Platonist was interested in speculative thought for the sake of its bearing on religious life. The highest fellowship with God, so it was believed, was to be attained by turning away as far as possible from all that was finite, and getting back to, and uniting oneself with the infinite by intense contemplation-contemplation passing over, at longed for but rare intervals, into ecstasy. Christianity triumphed over Neo-Platonism before the close of the fourth century; as Julian is reported to have confessed in his dying hour on the field of battle (363 A.D.) : "Thou hast conquered, O Galilæan."

But Neo-Platonism did not die; it lived on within the Christian Society. From the time of St. Augustine down to the present day NeoPlatonism, or at least the religious temperament of which Neo-Platonism is an outstanding example, has played a not unimportant part in the history of Christianity. Ever and anon there have emerged in Christendom men and women of religious genius, and with profound influence on the religious life of their day, whose affinities with Neo-Platonism have been as close as with Christianity in their interpretation of the religious life. They were disposed to believe, and to act on the belief, that God, the Infinite One, is the more surely reached, 


\section{The Christ of Faith}

the more completely we cut ourselves loose from the interests of the finite world, and that God is most fully enjoyed and served, not in a life of activity, but in the cultivation of the religious emotions of the contemplative quietist.

God so conceived cannot well be said to be God in Christ. God revealed in Jesus is more than the Infinite One ; $\mathrm{He}$ is the Father, whose loving will is present and at work in the finite world and in the history of humanity and in the events and experiences of the work-a-day life of His children. And God revealed in Jesus seeks indeed the closest fellowship of the individual soul with Himself, but a fellowship which does not end in religious contemplation, but is manifested and nurtured by the individual throwing himself trustfully upon life as God has planned it, and bearing himself as a loyal and heroic fellow-worker with God in carrying out His purpose to establish the Kingdom of God in the manifold spheres of the life of the children of the one Father.

A Neo-Platonic conception of God and of the religious life has been sometimes found in association with what is known as Christian mysticism. But here is it necessary to draw a distinction. A religious movement is not properly described as mystical, simply because it lays stress on the inner life of direct fellowship with God : else every truly religious man is a mystic. What is peculiar to 


\section{God Conceived and Worshipped}

mysticism properly so called is the conviction that God is essentially the Infinite, and that it should be the chief aim of a religious man to seek and to find in the Infinite One a refuge from the finite world and its interests. Now, Christian mysticism has only occasionally been dominated by this conviction in any exclusive sense. Its characteristic note has been that it has stood for " experienced" religion, for the immediate fellowship of the individual soul with God, for something more satisfying to man's deepest religious needs than mere assent to creeds, or observance of religious rites, or correct moral conduct. In spite of an occasional Neo-Platonic strain, it has emphasised the conception of God as God in Christ, and of the ideal religious life as the living over again of the life of Jesus. In Christian mysticism the "Galilæan" has, in the main, triumphed over the Neo-Platonist.

2. In another direction there has been a tendency to conceive of God as other than God revealed in Jesus. There was at least an obscuring of the conception of God as God in Christ when there prevailed in the Middle Ages and in still later times a tendency so to set God the Father over against God the Son, that the Father was conceived as the stern Judge, and the Son as the loving self-sacrificing Saviour. And this tendency was operative not only among the less intelligent Christian people. Theories 


\section{The Christ of Faith}

of the atonement were constructed by theologians, which suggest not an identity of will for the Father and the Son, but rather some kind of antithesisthe Father being conceived as manifesting the justice and wrath of God, and the Son as manifesting the suffering, self-sacrificing love of God. By such a conception of the relation of the Son to the Father, the love of God as well as the unity of God was compromised. "God in Christ" was lost sight of.

In the teaching of Jesus there is no suggestion of such an antithesis. It is the Father's love which calls and inspires Him to take upon His heart the burden of the miserable plight of His fellows. It is the strength of the Father's love which is made known in what Jesus dares to suffer in His passion "to seek and to save" the lost children of the Father. Everywhere and always it is the heart and will of the Father which the Son reveals.

In spite of occasional aberrations it has been a persistent and widely fruitful conviction all through the Christian centuries that the God with whom Christians have to do is God as $\mathrm{He}$ has been revealed in Jesus. Luther threw passion into his often repeated expression of this conviction. "For if we are certain of this: that what Jesus thinks, speaks and wills, the Father also wills, then I defy all that may fight against me. For here in Christ 


\section{God Conceived and Worshipped}

have I the Father's heart and will."' Of expressions of this conviction in modern times one or two may be quoted. "All specifically Christian theology," says a church historian, "is an expansion of ' $\mathrm{He}$ that hath seem me hath seen the Father.' ",2 "Few things," says a philosopher, " are more disheartening to the philosophical student of religion than the way in which the implications of the doctrine of the Incarnation are evaded in popular theology by dividing the functions of the Deity between the Father and the Son, conceived practically as two distinct personalities or centres of consciousness."3 In a chapter of autobiography by a gifted French lieutenant, a grandson of Ernest Renan, who fell in Belgium in the early months of the war, we have this striking sentence: "Man needs God : Jesus gives God to man by giving Himself."4 To the conception of God as God in Christ Browning recurs again and again as to one of his master thoughts :

The acknowledgment of God in Christ

Accepted by thy reason, solves for thee

All questions in the earth, and out of it. 5

I Lindsay, History of the Reformation, I, p. 474. Cf. Harnack's remark on this and similar passages in Luther's writings : "Confessing the deity of Christ could never become doubtful for him who knew-in the sense of believing in-no God at all save in Christ." History of Dogma, VII, p. I99.

2 Gwatkin, Early Cburch History, I, p. 2.

3 Pringle-Pattison, The Idea of God, p. $4 \circ 9$.

4 Ernest Psichari, A Soldier's Pilgrimage. English translation, p. 225.

5 .A Death in the Desert. 


\section{The Christ of Faith}

Jesus:]

[With reference to the story, told to the Arab physician about

The very God! think, Abib, dost thou think ? So, the All-great were the All-loving too.

But, it is asked, granted that the conception of God as God in Christ has all along been a dominant feature of Christianity, is there warrant from Jesus Himself for this conviction of the Christian Society? As has been already indicated, Jesus is conscious of a unique vocation to reveal the heart and will of God. Even if the words, "Neither doth any know the Father, save the Son" (Matt. xi. 27), were absent from our Gospels, the claims He makes elsewhere imply that in Himself, in His life and teaching as well as in His personality, there is a unique revelation of God. Apart from such evidence as has been referred to in chapter iv, there is an incidental touch in one of His parables, which may be worth noting. With reference to the charge brought against Him: "This man receiveth sinners and eateth with them" (Luke xv. 2), He tells the story of the prodigal son, in which the picture of the father is drawn from His own love for sinners, as if He Himself were the mirror in which can be seen the love of God. 


\section{CHAPTER XVI}

\section{The Fellowship and Unity of the Christian Society}

Speaking of the early centuries, Hatch says that "Christianity was, and grew because it was, a great fraternity." "All down through the early centuries," says another Church historian, "this idea that Christians formed one brotherhood finds abundant expression. Brotherhood alternates with Ecclesia in the oldest sets of ecclesiastical canons, while omnis fraternitas and $\pi \hat{\alpha} \sigma a \dot{\eta} \dot{a} \delta \epsilon \lambda \phi o ́ \tau \eta$ s are used to denote the whole of Christendom."2 This feature of the Christian Society impressed unsympathetic observers. "Their first lawgiver," said Lucian, " had imbued them with the conviction that they were all brothers to one another; they develop an incredible sensitiveness, as soon as anything happens which touches their common interests; nothing is then too costly for them." 3 It is in

I The Organization of the Early Cbristian Cburcbes, p. 44 .

2 Lindsay, The Cburcb and the Ministry, p. 21.

3 Harnack, Die Mission und Ausbreitung des Cbristentbums, p. 107. 


\section{The Christ of Faith}

view of this recognition "that we are denoted by the title of "the brethren." 'Tertullian makes his oft-quoted remark: "It is the exercise of this sort of love which doth, with some, chiefly brand us with a mark of evil: 'See,' say they, ' how they love each other . . . and see how ready they are to die for each other.'"

Fellowship was one of the outstanding " notes" of the Christian Society. Its singular fruitfulness was due to the depth of the spiritual experience in which it had its roots. The members of the Christian Society were bound to one another by devotion to a common Lord, which was identified with devotion to the things which seemed to them to give life its worth and grandeur and joy. In devotion to their Lord they learned to see the fatherly love of God at the heart of their own life and of the life of the great world; to face life's tasks and trials with the confidence and courage of children who were very sure of the God and Father of their Lord Jesus Christ. In devotion to their Lord they were made aware of an appeal to the noblest and most generous instincts which had ever stirred them in their best moments. In devotion to their Lord they were called upon to take part, hopefully and bravely, in making real, here on this earth, the ideals of that Kingdom of God whose full consummation belonged to eternity.

I The Apology, 39 . 


\section{Fellowship and Unity of Christian Society}

Those who lived on the high levels of the new life of faith and hope and love could not well be content with religious individualism, however intense and genuine this might be. Such individualism was alien to the ideals of their Lord. Jesus had indeed laid stress on the infinite worth of the individual and on the filial fellowship of the individual with God. But such fellowship, as interpreted by Jesus, led the individual out of his narrow self into fellowship with the one Father's children. The God of love could best be found and served, not in solitude or self-centredness, but in a fellowship of Christians with one another which gave scope for love-for love's service, love's suffering, love's gladness. Besides, Jesus as Leader in the Kingdom of God called His followers to be His helpers in His great enterprise for humanity; and so far as Christians were here loyal to their Leader, their comradeship was inevitable. In whatever direction we look, the fellowship of the Christian Society would seem to be indissolubly bound up with devotion to Jesus and His ideals.

We need not wonder that fellowship with one another was regarded by the Christian Society as something precious, to be jealously guarded and fostered. It meant so much. Each individual Christian found in it heartening and inspiration. He was no solitary unit; he was a brother in a great fraternity, a soldier in a noble army, a citizen 


\section{The Christ of Faith}

of the Kingdom of God. He was a comrade of all who owned Jesus as Lord, and such comradeship was a perennial source of strength for his individual decisions and struggles.

Each individual Christian was a sharer in the fellowship of his particular Christian community, of his local ecclesia. But the local ecclesia was part of a greater whole-the one ecclesia, the one society of those who owned Jesus as Lord. So each individual Christian could feel himself linked with his fellow Christians of every land, of every race, of every class-rich and poor, educated and uneducated, freeman and slave. And the more he fostered, by his brotherly thought and brotherly service, the sense of this world-wide fellowship, the richer was the boon of Christian fellowship for his individual life.

Further, each individual Christian could feel himself linked not only with the Christian Society of his own day, but with the Christian Society of all the past generations. He was encompassed with a great cloud of witnesses, heartening him in the race set before him. He was an heir of the traditions, cherished by the Christian Society, of what devotion to their Lord could inspire men and women to be and do; of the traditions of the Christ-like lives of saints and heroes, prophets and martyrs, lovers of God and lovers of men. He was in the line of succession to the life of faith and hope and love, 


\section{Fellowship and Unity of Christian Society}

which stretched back through the generations to Jesus and His apostles; and serving himself heir to so great a heritage, he could not but be spurred to prove himself not unworthy of a place in the long line of Christ-like men and women.

In expounding his ideals of a true Catholicism Father Tyrrell gives expression to thoughts which evoke a warm response far beyond the pale of the church which supposes itself to be peculiarly identified with them. "Though the one thing needful," he says, "is communion with the invisible Church (i.e., with God as presented to us in Christ, and in all Christ-like men, past, present, and future; with all those who, whatever their professed creed, in any way or degree suffer and forsake themselves for God's cause and God's will) yet communion with the visible Church, with those, namely, who profess to be Christ-like, is a great desideratum, is a condition of more fruitful communion with the invisible." " By our identification with this external society (so far as it is a vital and voluntary and not merely a mechanical and passive adhesion) our separate weakness is supplemented by a participation in its strength and resources; we are borne up by the crowd, carried along by its rush. Our convictions are stronger, our purposes firmer, our feelings are keener for being consciously shared by the whole world we live in. Our courage and hope

I A Mucb Abused Letter, pp. 62, 63. 


\section{The Christ of Faith}

and confidence are measured by our sense of the strength of the army to which we belong, of the history of its past victories."

The Christians of the early centuries, with their high estimate of the worth of fellowship with one another, could not help making much of the unity of the Christian Society. How largely the idea of unity bulked in the thoughts of the men of the apostolic age is evidenced by many a passage in St. Paul's letters; by such a passage as this: "Giving diligence to keep the unity of the Spirit in the bond of peace. There is one body, and one Spirit, even as also ye were called in one hope of your calling; one Lord, one faith, one baptism, one God and Father of all, who is over all, and through all, and in all " (Eph. iv. 3-6). It is also evidenced by the prominence given in the fourth Gospel to the prayer of the Lord " that they may all be one; even as thou, Father, art in me, and I in thee, that they also may be in us : that the world may believe that thou didst send me" (John xvii. 21). In the beginning of the second century Ignatius, in his letters written to several Christian communities on his way to martyrdom in Rome, makes repeated appeals to Christians to safeguard their unity against " lawless isolation and self-will." "Cherish union; shun divisions." "Have a care I A Mucb Abused Letter, pp. 82, 83 .

2 To the Pbiladelphians. 


\section{Fellowship and Unity of Christian Society}

of unity, than which nothing is better." "For, being counted worthy to bear a most godly name, in these bonds, which I carry about, I sing the praise of the churches; and I pray that there may be in them union of the flesh and of the spirit, which are Jesus Christ's, our never-failing life-an union of faith and love which is preferred above all things."” More than a century later Cyprian, in his short tractate on the unity of the Church says : "There is one Church which outspreads itself into a multitude (of churches), wider and wider in ever increasing fruitfulness, just as the sun has many rays but only one light, and a tree many branches yet only one heart, based in the clinging root; and while many rills flow from one fountain-head, although a multiplicity of waters is seen streaming away in diverse directions from the bounty of its abundant overflow, yet unity is preserved in the head spring." 3

The chief bond of unity for the Christian Society was not a compact organisation, to which all the members belonged, but the common life of faith and hope and love. Unity was not dependent on a compact organisation. In the apostolic age there was as yet no such compact organisation as was gradually developed in the second and subsequent centuries, but the unity of the Christian Society seems to have been more real than in later
I To Polycarf.
$2 \mathcal{T}_{0}$ the Magnesians.
3 Benson's Translation. 


\section{The Christ of Faith}

times. That does not mean that the development of a compact organisation was in itself a mistake. An expanding movement involves an expanding organisation. The expanding organisation was developed on the lines of episcopal government. That this particular method of expressing and fostering the unity of the Christian Society was suitable for the times in which it was developed, is suggested by the fact that from at least the end of the second century it was almost universally accepted, and apparently without protest in favour of any other method.

This compact organisation was a means to an end-the promotion of that unity of the Christian Society, which was rooted in the one Christ-imparted life, shared by all its members. But there was a risk of the external framework for the promotion of unity coming to be more highly valued than the unity of spirit, whose interests it was meant to subserve. It was easier for the " natural man" to be more enthusiastic about the external framework than about the spiritual life which was the real bond of unity.

There were many separate churches in those days, often as bitterly opposed to each other, as ever have been the separate churches of modern Christendom. Schisms and secessions were abundant, unseemly strifes, un-Christlike tempers, wild and whirling words. What came to be known as the 


\section{Fellowship and Unity of Christian Society}

Great Church stood out, amongst the multiplicity of separate churches, as the most widespread and influential body of Christians, and itself claimed to be the only true church, outside of which there could be no salvation. As Cyprian put it: " $\mathrm{He}$ can no longer have God for a Father, who has not the church (that is, the Great Church) for his mother." So the unity of the Christian Society came to be conceived as bound up with membership in the compact organisation of the Great Church; and as an inevitable consequence, the unity of the external framework tended to be more thought of than the unity of a Christ-inspired life-with many unhappy consequences. Members of the Great Church were encouraged to set more store by their connection with the dominant ecclesiastical organisation, than by the Christ-life which was often manifested by the "schismatics." And in their zeal for furthering the interests of the " only true church" they pursued the "schismatics" with a scorn and hatred which convicted them of disloyalty to the spirit of life in Jesus Christ, of disloyalty to that in which the real unity of the Christian Society alone consisted.

There were disastrous aberrations in this

I Newman quotes, apparently with approval, the words of Fulgentius, a bishop of the sixth century: "Most firmly hold and doubt in no wise that every heretic and schismatic soever, baptised in the name of the Father, Son and Holy Ghost, unless brought into the Catholic Church, how great soever may have been his alms, though for Christ's name he has even shed his blood, can in no wise be saved." Essay on Development, p. 267. 


\section{The Christ of Faith}

direction as early as the fourth century; in later centuries they became appalling. The magnifying of the unity of the external framework over the unity of the spirit of life in Christ Jesus has here much to answer for. But the sense of the higher unity of the Christian Society has never quite been lost. Even in those churches which have been most uncompromising in exalting their own particular organisation as indispensable for a true Christian life, there have ever been Christian men and women who have felt themselves to be one with all who love the Lord Jesus and manifest their love by a Christlike life; and it is they, and such as they, whatever may be their "sheep fold," who are the truest defenders of the unity of the Christian Society.

Is this emphasis on the fellowship and unity of the Christian Society in accordance with the ideals of Jesus? It may be natural for the disciples of a religious teacher to draw to one another and form themselves into groups for the propagation of the Master's teaching, but is the quite extraordinary emphasis which has been put upon the Christian Society a legitimate outcome of the activity of the Prophet of Nazareth ?

But, let it be repeated, Jesus claims to be more than a prophet. As Leader in the Kingdom of God He calls for an exceptional loyalty to Himself- 


\section{Fellowship and Unity of Christian Society}

a loyalty which involves the fellowship and comradeship of His followers with one another. It involves also a unity of His followers as world-wide as His vision of the Kingdom of God-such a unity of heart and will as the oneness of the Father and the Son. 


\section{CHAPTER XVII}

\section{Sacramentarianism ${ }^{\mathrm{x}}$ : Lowering the Con- ception of the Grace of God in Christ}

THE word grace does not occur in the recorded sayings of Jesus, but what it connotes is prominent in His teaching and in His life. It is through His teaching and life that grace has become so significant a word for the Christian Society. It points us to the spiritual experience which is rooted in the revelation by Jesus of the Fatherhood of God and of man's filial fellowship with God. The grace of God is the fatherly love of God experienced by His children-such fatherly love as is pictured for us in the father of the prodigal son. This grace is no mere remission of the penalty of sin; it is something infinitely greater; it involves restoration to the glad life of the true home of the spirit of man, to trustful loving fellowship with the Father, and to the peace, heartening and inspiration which spring from such fellowship. The experience of the grace of

I "Sacramentarianism," "Sacerdotalism," "Orthodoxy," are terms which may be used to designate what is in profound harmony with the ideals of Jesus. They are used here in their depreciatory sense-not without reluctance; but there seem to be no other terms equally suitable to express what the writer has in view. 


\section{Sacramentarianism}

God is a constant factor in the life of sonship. God is Father, and as Father is ever calling His sons to be His fellow-workers, and ever backing them up with all the resources of fatherly love and fatherly fellowship-backing them up with His grace.

A growing experience of the grace of God in the struggle to realise the ideals of love and service and heroic goodness, set before us in the life of Him who was the Son of God, is an abiding feature of Christian discipleship. Everywhere and always the Christian is called upon to let the grace of God in Christ lay its power upon him and transform him. There is no event or experience which may not become the occasion on which, or the vehicle through which, the grace of God works in his heart, to comfort, purify, or inspire. In the dear sanctities of the home, in what we gain from and contribute to a friendship, in the discharge of the duties of our station, in service to the common weal, in work and recreation, in joy and sorrow, in trials and temptations, even in the rain and sunshine, in the wayside flowers and the birds of the air, we can find a means of grace. From this point of view all life is justly said to be sacramental-sacramental for those who yield themselves to the gracious influence of God who has His dwelling place in the loyal heart. For there can be no experience of the grace of God in Christ, apart from receptivity on the part of man. 


\section{The Christ of Faith}

The Christian Society all through its history from the apostolic age to our own day has found special means of grace in common worship, and, above all, in " the breaking of bread." Through the bread and wine of the eucharistic service receptive worshippers are brought into effective touch with the most amazing manifestation of the grace of God in Christ-its manifestation in the love which gave itself "for us men and our salvation" unto death, even the death of the Cross. It is therefore natural that the Christian Society should give to the eucharist the central place in common worship. The ordinance is observed with widely diverging forms of ritual, but with the simplest as well as with the most elaborate ritual it is " a singular medicine for all poor sick creatures, a comfortable help to weak souls." Communicants who open their hearts to the grace of God in Christ, as it presses in upon them through the sacramental bread and wine, have a fresh experience of filial fellowship with the God and Father of the Lord Jesus Christ ; of His forgiving love; of His strengthening for the life of unworldliness, pureheartedness, and brotherly service; of His heartening for facing life's difficulties and sufferings and heartaches with radiant and victorious energy.

If in the eucharist there is such a very real experience of the grace of God in Christ, then God I John Knox's Liturgy. 


\section{Sacramentarianism}

in Christ is really present in the sacrament. There is, of course, a commemoration of the wondrous love which found its highest expression in the broken body and poured out blood of the sufferer on the Cross of Calvary, but that commemoration is robbed of its significance, unless the communicant is thereby brought into living and fruitful touch with God in Christ really present to the heart. ${ }^{\mathrm{T}}$

We assume, then, that there is nothing in the whole round of human life which may not be the occasion of the Christian experiencing the grace of God in Christ; that the eucharist cannot be too highly valued as such an occasion; that through the sacramental bread and wine there is a real presence of God in Christ to the worthy communicant. What then is sacramentarianism, when the term is used in a depreciatory sense ?

We may be helped to answer this question, if we consider how the phrase " a valid eucharist" is interpreted by sacramentarians. According to their interpretation, the eucharistic service may be the means of furthering the fellowship of the

I In the Middle Ages there was a tendency to conceive God as too exclusively transcendent, as the Absolute of the philosophers. The doctrine of transubstantiation was an attempt to modify the conception of God as transcendent, and to represent $\mathrm{Him}$ as immanent in the bread and wine of the sacrament, and thereby immanent in the worthy communicant. But when God's immanence in man's heart and conscience is duly recognised, there is no longer need of such strange speculations to set forth the real presence of God in Christ in the eucharistic service. 


\section{The Christ of Faith}

communicant with God in Christ, the means of gaining a fresh experience of the grace of God in Christ for strengthening the life of faith and hope and love, but it is not a "valid" eucharist unless it is administered by a priest ordained by a bishop, who has himself been consecrated by bishops, who can trace their consecration, through a long line of a succession of bishops, to the apostles themselves. Not "valid" for what? For fostering the spiritual experience in which the communicant yields himself to the grace of God in Christ? No ; apparently for something over and above such experience, and it is in connection with this "something" that sacramentarianism emerges for this and other sacraments.

What is this something?

We may get a clue to the answer, if we look at the sacramental system as developed in the Middle Ages. In regard to baptism, it was believed that baptised infants were made sure of the remission of the eternal penalties due to original sin. In regard to penance it was believed that penitents who came to confession were assured, through the absolution spoken by the priest, of the remission of the eternal penalties of post-baptismal sins. In regard to the eucharist it was believed that, through the sacrifice of the body and blood of Christ renewed in the Mass, propitiation was made to God for the sins of the worshippers and that Masses for the dead so availed 


\section{Sacramentarianism}

to propitiate God as to shorten the period of suffering for souls in purgatory. ${ }^{\mathbf{T}}$

Now, as far as this aspect of the sacraments is concerned, the attention of the worshipper was directed, not to a personal experience of the forgiving love of God in Christ, but to an escape from the eternal or temporal penalties of sin ; not to a personal experience of the grace of God for transforming heart and life, but to the assurance of divine grace in remitting sin's penal consequences.

There were, of course, spiritually-minded worshippers who concerned themselves little with escape from the penal consequences of sin, in comparison with escape from an evil heart. Loving God for His own sake, they could have made their own the confession of Thomas à Kempis : "I rather choose to be a pilgrim on earth with Thee, than without Thee to possess heaven. Where Thou art, there is heaven : and where Thou art not there is misery and death.", Loving goodness for its own sake, they were more intent upon becoming good than upon escaping the consequences of being bad. And even with worshippers who were not in an exceptional degree spiritually minded, there must often have been higher thoughts and aspirations, as they participated in the sacraments, than those aspect.

2 The Imitation, III, p. 59. 


\section{The Christ of Faith}

which were concentrated on the remission of penalty. But the remission of penalty did have a more or less prominent place in at least three of the sacraments.

With regard to the sacraments in general, it was assumed that, in addition to the experience of the grace of God which could be mediated in an ordinary way through the fellowship of the Christian Society and similar channels, there was a divine blessing - a sacramental grace-which God could bestow upon men in no other way than through the appropriate sacrament.

With such conceptions of the sacraments, the idea that they could only be "valid," if administered by a duly ordained priest, was at least intelligible. There was "something" here which, it might be said intelligibly, could only be communicated through some supernatural power with which the priest was invested. The eucharist, for example, if administered (or supposed to be administered) by one who was not a duly ordained priest, might be the means of fostering the religious and ethical life of the communicants, but would not therefore be "valid" for securing remission of the penalty of sin for souls in purgatory.

The full-blown sacramentarianism of the Middle Ages was the result of a long and slow development. But tendencies towards such sacramentarianism manifested themselves in the 


\section{Sacramentarianism}

" undivided Church." In the earlier centuries of that period it often happened that grown-up persons, reared within the Christian Society, deliberately refrained from being baptised till a later timeon the ground that, according to a current belief, the sacrament of baptism was a sure means of securing the remission of the penal consequences of whatever sins had been committed up to the date of baptism. A little later, however, infant baptism became the rule for the children of Christian parents, for there had grown up a serious doubt whether even such children, if they died unbaptised, could be saved from the eternal punishment due to their original sin. Again, while Justin Martyr, in the second century, can say that " prayers and giving of thanks, when offered by worthy men, are the only perfect and well-pleasing sacrifices to God," Cyprian, in the third century, speaks of the specific sacrifice offered by the priest in the eucharist as " the passion of the Lord" - as if to suggest " that the Holy Supper is a repetition of the agony and death of our Lord on the Cross," changing the attitude of God to the sinful worshipper.

In Mediæval Christianity, then, and, to some extent at least, in the Christianity of "the undivided Church" the sacraments were believed to mediate a "grace" of God in Christ, which-for example,

I Lindsay, The Church and the Ministry, p. 3 ro. 


\section{The Christ of Faith}

the remission of the penalty of sin-is outside spiritual experience, and which can be obtained in no other way than through the ministration of a duly ordained priest.

How far "Catholic" Anglicans dissociate themselves from the sacramentarianism of the Roman Catholic Church, it is not always easy to discover. For some of them, at least, the "something" more than can ever be obtained in sacraments as administered in non-episcopal churches is a very real thing, belongs, indeed, to the essence of Christianity. They do not always succeed, as the Roman Catholics do, in explaining what exactly this real thing is. But even where it may be little more than the ghost of Roman sacramentarianism, it operates as a real thing. It is real enough to raise a thorny hedge between themselves and non-episcopal churches. It is real enough to warrant Dr. Gore in putting forth a solemn and repeated warning "that the Anglican communion would certainly be rent in twain on the day on which any non-episcopally ordained minister was formally allowed within our communion to celebrate the Eucharist."

Sacramentarianism, as many who sympathise with it admit, has been a development. Has one factor in the development been the influence upon 


\section{Sacramentarianism}

the Christian Society of its environment in the Græco-Roman world ? It used to be assumed by Tractarians as well as by Roman Catholics that from the apostolic age the Christian Society addressed itself to the great enterprise of winning the allegiance of all men to Jesus as Lord, with "the once for all delivered faith," "the fulness of the once for all given grace," "the visible society once for all instituted," "a once for all empowered and commissioned ministry" $;^{\mathrm{I}}$ and that any influence, in subsequent ages, of the environment upon the creeds and institutions of the Church is negligible. Newman did a service to historical science by stirring doubts as to the assumption of the definiteness and extent of the original equipment of the Christian Society. "The Church," he says, "can convert heathen appointments into spiritual rites and usages." "The rulers of the Church from early times were prepared, should the occasion arise, to adopt, or imitate, or sanction the existing rights and customs of the populace, as well as the philosophy of the educated classes."3 "Outward rites, which are but worthless in themselves, lose their own character and become Sacraments under the Gospel." 4 He takes for granted, of course, that

I Gore, The Cburcb and the Ministry, p. 64. In the third edition, " the once for all given grace " is altered to " the fulness of the Spirit's presence and operation once for all granted to the Church."

2 Essay on Development, p. 365.

3 Ib.d., p. 358.

4 Ibid., p. 355 . 


\section{The Christ of Faith}

whatever was taken over from the environment, and stamped with the approval of the Church, was in harmony with the genius of Christianity. Since Newman's Essay was published, more light has been thrown upon the environment of the Christian Society in the centuries when sacramentarianism was being developed, and such additional light has not availed to allay the suspicion that sacramentarianism has intruded itself into Christianity through the influence of conceptions of the God-head and of acceptable sacrifice which prevailed among the Gentile peoples with whom the Christian Society was brought into contact.

It is pleaded on behalf of sacramentarianism that it can claim the authority of Christ and His apostles, and passages are quoted from the New Testament, and also from the Old Testament, in support of the plea. But it is difficult to see how it can be brought into harmony with the regnant ideals of Jesus.

The prominence given in connection with more than one of the sacraments to the remission of the penalties of sin seems to take us into another atmosphere than that which we breathe, as we company with Jesus in the pages of the Gospels. He speaks, and in awe-inspiring language, of the ruin in which disloyalty to God and goodness has its inevitable issue. But what stirs His pity-His redeeming pity 


\section{Sacramentarianism}

-is the disloyalty itself. What $\mathrm{He}$ seeks for sinful men and women is not well described as escape from the external penalties of sin. It is a new life, the life of Sonship, with its experienee of the forgiving love of God, with its vision of heights of heroic goodness, with its sense of God's fatherly, helpful presence in the heart to strengthen for every noble struggle and for every loving ministry. This life is itself salvation from ruin.

In regard to the wider aspects of "sacramental grace," there is no hint in the teaching of Jesus that the fatherly, helpful love of God is in certain directions vouchsafed only to those who make use of prescribed religious rites which can only be duly administered by a priestly class of His disciples. Such a conception seems to be at variance with His conviction of the nearness of God to the hearts of His children, and of the ceaseless energising of a fatherly love which has no delight in imposing restrictions on its outflow. 


\section{CHAPTER XVIII}

\section{Sacerdotalism : Narrowing the access to God in Christ}

IN passing to the consideration of that type of sacerdotalism which inevitably goes along with sacramentarianism, it may be well at the outset to refer briefly to the development of the Christian ministry in the early centuries.

In the apostolic age the most prominent feature in the Christian ministry-apart from the apostles with their special functions-is the college of elders.

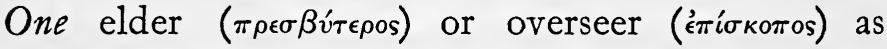
permanent president is not yet recognised, or at least not commonly recognised. At the beginning of the second century a threefold ministry is recognised as the normal organisation of a Christian congregation-one overseer (the bishop), with his college of elders, and with a number of deacons to assist the bishop and elders, especially in caring for the poor, widows, orphans, and strangers. This is not yet diocesan episcopacy : the machinery for linking the various congregations into a compact ecclesiastical organisation is not yet in existence. 


\section{Sacerdotalism}

This three-fold Christian ministry involved neither the episcopal nor presbyterian form of church government, as these are known to us to-day. It is a ministry for the individual congregation, and finds its counterpart in the ministry of the congregation in Congregationalist and Presbyterian churches. ${ }^{x}$ With the further expansion of Christianity this threefold ministry developed-legitimately, let it be granted-in the direction of diocesan episcopacy. The bishop of a congregation came, especially in the cities, to have several additional congregations under his charge, and delegated the oversight of these to members of his college of elders. That is, the bishop of the earlier period, who was in almost all cases the chief minister for a single congregation, was now approximating to the status of a diocesan bishop. From the third century onwards the episcopate which was being developed on these lines, became a chief factor in expressing and fostering the organised unity of the Christian Society. For example, it was mainly by means of the episcopate that the work of the assemblies, representative of the greater part of Christendom-the œcumenical Councils-was accomplished.'

It was on this threefold ministry sacerdotalism was grafted, not earlier than the third century. It

I Can it be taken for granted that at Lambeth Conferences and elsewhere this, the earliest form of the " historic episcopate," is not kept out of view ? 


\section{The Christ of Faith}

was a graft-no branch of the original tree. The writers of the New Testament were familiar with the Jewish priest and priestly institutions, but they never

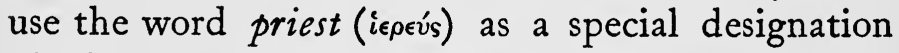
of the presbyter ( $\left.\pi \rho \epsilon \sigma \beta \hat{u}_{\tau} \epsilon \rho o s\right)$ or of any officebearer of the Christian Society. They do indeed speak of Christians as priests, but with reference to all Christians and not to any special class. When we meet in the second century with the three-fold ministry-bishop, elders, deacons-the bishop and elders are not spoken of as priests in a sense in which all Christians could not be so designated. But in the middle of the third century we find that bishops and presbyters are being regarded, notably by Cyprian, as a priestly class in distinction from all other office-bearers, and of course from the ordinary members of the Christian Society. Naturally enough, for bishops and priests were supposed to offer in the eucharist a specific sacrifice-" the passion of the Lord"-by which the attitude of God to sinful worshippers might be affected. This was a distinct innovation, and an innovation due, not to development in adapting the ideas of original Christianity to new circumstances, but to the influence of conceptions of God and of the means of appeasing $\mathrm{His}$ anger, which were current in the Gentile environment but were alien to the conceptions of Jesus. Once there had crept in the idea of the necessity of such specific sacrifices, and 


\section{Sacerdotalism}

of the need of specific priests to offer them, resort was had, in support of the innovation, to that priestly system of the Old Testament from which the Christians of the apostolic age had definitely dissociated themselves. Bishop and presbyters (with the attendant deacons) were the counterpart of high priest and priests (with the attendant Levites); they discharged functions similar in certain respects to those of the Jewish priesthood; they were invested with a divine authority over the members of the Christian Society, similar in certain respects to that exercised by the Jewish priesthood over the people of Israel.

This conception of priesthood was, as we have said, a new thing in the Christian Society. When the priesthood of all Christians was recognised, the presbyter as the presiding minister of a congregation might fitly enough be called a priest-a priest representative of the members of the congregation exercising their own priestly functions of offering to God in the eucharistic service the sacrifice of prayer and thanksgiving, and of their whole heart and life. But the priest, as now conceived, was more than a representative of his fellow-worshippers, he was a mediating priest, who could do for them something which it was impossible for them to do for themselves. This "something" might at first be confined for the most part to the celebration of the eucharist, but as the priestly system developed, I89 


\section{The Christ of Faith}

the idea gained ground more and more that the grace of God could be bestowed upon the worshippers only through the mediation of the priest. How necessary this mediation of the priest was conceived to be in the Middle Ages is illustrated by the extraordinary method devised by the Church for punishing a town or country for some action resented by the ecclesiastical authorities. An interdict was issued, forbidding the celebration of sacraments by the priests, till the offending town or country gave satisfactory evidence of penitenceas if the awful plight of being deprived of the grace of God would bring the people to their senses. (A curious way of trying to make bad people good, by depriving them of the divine grace by which they could become better !)

This mediating priesthood, claiming the possession of "specific and exclusive" power of communicating the grace of God in Christ, may have had a wholesome influence in many directions. But while every form of Christian miristry has its latent dangers, the sacerdotalism of such a mediating priesthood has specific dangers.

Sacerdotalism tends to intensify the conception of God as transcendent, far off from man, difficult of access by man. The conception of God in Christ, as a loving Father ever near to His children in their weakness and struggle and sin, falls into the 


\section{Sacerdotalism}

background. Through priestly mediation devout worshippers may indeed have experience of filial fellowship with God, but the insistence upon the absolute necessity of priestly mediation inevitably obscures the thought of God pressing in, always and everywhere, to the heart of His children with His grace in Christ. So we find the wide-spread idea that if worshippers are to secure the grace of this transcendent God, they act wisely, not only in resorting to the priest and his priestly ministrations, but in praying to the martyrs and saints and, above all, to the Blessed Virgin to make intercession with God on their behalf.

Sacerdotalism tends to cause less stress to be laid upon the spiritual character of those who discharge the functions of the ministry. So far as regard was had, in the administration of the sacraments by the priest, to the experience on the part of the worshippers of the furtherance of their Christlife, the personal character of the ministrant could not be left out of account. But so far as the sacrament was regarded as a means of obtaining divine grace outside the experience of the worshippersfor example, the remission of the eternal or temporal penalty of sin-the personal character of the ministrant did not seem so essential for its due administration. So, in days when evil-living priests were not uncommon, it was explained authoritatively to the people that the efficacy of the sacrament was 


\section{The Christ of Faith}

not affected by the bad character of the ministrant, though the ministrant himself might be adjudged guilty of mortal sin. Here we have a malign opening for that divorce between religion and morality, which, in the period of the Renaissance, became so acute, especially in Italy, and most of all in the papal court, that a non-ecclesiastical historian, who devoted his life to the investigation of this period, sums up his impressions in these words: "To overestimate the moral corruption of Rome at the beginning of the sixteenth century is almost impossible."

Sacerdotalism tends to widen the gulf between the clergy and the laity. In the Christian Society of the apostolic age this gulf is scarcely discernible. When all the members were conceived as endowed with special spiritual gifts for their own special ministry, there was a distinction, of course, not only between different grades, but between different kinds of ministry, but there could not well be a sharp distinction of two definite classes-the clergy, who ministered to the Christian people, and the laity to whom the clergy ministered. Each was a minister to all, and all were ministers to each. After the threefold ministry of bishop, elders and deacons was recognised in the second century as the normal equipment of a Christian community, the fact that for more than a century most of the presbyters I Symonds, Renaissance in Italy, II, p. 294. 


\section{Sacerdotalism}

and many of the bishops earned their means of livelihood in much the same way as their fellowChristians, precluded the drawing of a sharp distinction between clergy and laity. The situation was somewhat altered, when, with the expansion of Christianity, the services to the Christian community expected from the bishops and elders were so increased that it became customary to set them free from the necessity of earning their own livelihood. This change tended in the direction of the distinction between clergy and laity. But the chief factor was the new idea that bishops and presbyters were priests in a special sense, and performed special priestly functions, as did the priests of the Old Testament and the priests of the imperial statereligion and of the old national religions. When bishops and presbyters were believed to be invested with a "specific, exclusive" power of mediating through the sacraments the grace of God to the worshippers, the sacerdotal hierarchy came to regard themselves, and to be regarded by others, as a separate class, and to claim an ever-widening authority over the rest of the Christian Society. It belonged to the sacerdotal hierarchy to rule, and to the Christian people to obey; it belonged to the sacerdotal hierarchy to teach, and to the Christian people to learn. With such a sharp distinction between clergy and laity, spiritual loss was incurred by both. On the one hand, the laity, 


\section{The Christ of Faith}

kept in tutelage, were not encouraged to exercise all their spiritual gifts for promoting the wellbeing of the Christian Society; they were not encouraged, for example, to co-operate with the clergy in enriching the thought of the church or in shaping its policy. On the other hand, the clergy, failing to turn to the best account the vast spiritual resources latent in the special gifts of head and heart among the laity, lost a powerful safeguard against abuses which prevailed in the church, and which the best bishops and priests deplored, and endeavoured, too often with little success, to remedy.

But let it be borne in mind that these tendencies which seem to be inherent in sacerdotalism were often counteracted, outside the sacerdotal hierarchy, and to a less extent inside it, by tendencies of a quite different kind. For example, over against the conception of God as far off and transcendent, which seems to be logically involved in sacerdotalism, there has to be set the wide-spread and persistent vogue of religious mysticism, which laid the whole stress on the immanence of God, on His direct presence to the heart of man. Here there is no need of a mediating priesthood. "God and the soul, the soul and its God "- that is the watchword of mysticism. So, many devout Christians, to whose own religious experience sacerdotalism was alien, thought less of sacramental institutions than 


\section{Sacerdotalism}

of direct fellowship with God in the sanctuary of the heart. Nor were they necessarily frowned upon by the ecclesiastical authorities. So long as they did not attack the institutions of the church, they might reckon on the church's benediction. For mysticism had had its place in the church since the days of Augustine. One of the greatest of the churchmen of the Middle Ages, Bernard of Clairvaux, was one of the greatest of the mystics. Ever and anon there were revivals of mysticism, revivals of experienced religion. In the fourteenth and fifteenth centuries mysticism was an extraordinarily powerful movement in Germany, Switzerland and the Netherlands. Of the mystics of that period the best known is Thomas à Kempis, and we can gather from the Imitation how little sacerdotal mediation, and how much direct communion with God, meant for their religious life. So acknowledged a place did this mystical religion seem to have alongside of sacerdotalism, that Luther may well be excused for believing, at the outset of his career as a reformer, that he was but giving expression to the better mind of the church which had nurtured him.

Again, if sacerdotalism, by asserting that the efficacy of the sacrament was not affected by the bad character of the ministrant, tended to make a divorce between religion and morality, this tendency was counteracted by all that the church, in 


\section{The Christ of Faith}

accordance with the teaching of Jesus in the Gospels, taught about the indispensableness of a good life. The church herself had so educated the conscience of the Christian people that again and again they broke out in hot protest against the evil lives of many of the clergy, and clamoured for the redress of scandalous abuses by means of Councils and other machinery. The Mediæval church, in spite of its sacerdotalism, thus played its own part in preparing the way for the service rendered to Christendom by the reformers of the sixteenth century.

Roman Catholics and the "Catholic" party in the Church of England claim the authority of the apostles and of Christ for their sacerdotalism. How they endeavour to make good that claim from Scripture and the history of the Church is a question the discussion of which is outside our present purpose. What concerns us is the bearing upon sacerdotalism of the ideals of the Jesus of history.

The conception of a priesthood to mediate between a worshipper and a transcendent God transports us, as we have said in regard to sacramentarianism, into another atmosphere than that which we breathe as we company with the Jesus of the Gospels. Jesus habitually thinks and speaks of God as Father. His emphasis on the Fatherhood of God is one of the prominent features of His teaching, and the Fatherhood of God means His 


\section{Sacerdotalism}

nearness to the heart of man-the nearness of a Father to His children. The experience of filial fellowship with God is at the very heart of the religious life, as interpreted by Jesus. The child of God can come into direct touch with his Father without the mediation of a priest, as the prodigal son needs no intermediary to assure him of his father's forgiveness and welcome. He goes direct to God with his prayer for forgiveness: "Our Father which art in heaven . . . forgive us our debts." It is with no far-off transcendent God he is in relation, who communicates blessings to him through the mediation of priestly rites; he lives habitually in communion with an ever present, indwelling God, by whose grace he is continually beset and strengthened. "No one knoweth the Father save the Son, and he to whomsoever the Son willeth to reveal him." To know the Father as Jesus knew Him is to live

With God in such untroubled love

And clear confiding, as a child on whom

The father's face has never yet but smiled.

If a priest " is one who represents God to man, and man to God," Jesus, though He does not use the term with reference to Himself or to His followers, does recognise what the term, as thus interpreted, stands for. $\mathrm{He}$ is the High Priest, who brings to man a new vision of God, and who draws man to 


\section{The Christ of Faith}

his true home in God. And Jesus looks to His followers to be priests, after this order, to their fellows ; so to reveal God in their character and life and words, as to draw them God-wards: "Ye are the light of the world . . . neither do men light a lamp, and put it under the bushel, but on the stand; and it shineth unto all that are in the house. Even so let your light shine before men, that that they may see your good works, and glorify your father which is in heaven" (Matt. v. I4-16). There is no hint that the efficacy of such priestly ministration is not dependent on the character of the ministrant. On the contrary, we have a saying such as this: "Ye are the salt of the earth: but if the salt hath lost its savour, wherewith shall it be salted ? it is thenceforth good for nothing, but to be cast out and trodden under foot of man" (Matt. v. I3). 


\section{CHAPTER XIX}

\section{Orthodoxy: Magnifying Assent to Theo- logical Doctrines about Christ over loyalty to Christ in heart and life}

IN the second century, as in all the centuries, Christians had these two convictions: that Jesus whom they acknowledged as Lord was a unique personality, and that the God with whom they had to do was God revealed in Jesus. These convictions were the outcome of their experience of what Jesus, ever present by His spirit, had been to them. Such an experience, centred though it was in heart and conscience, could not fail to stimulate thought, in many cases to set up an intellectual ferment. Special opportunities for the exercise of thought upon their spiritual experience were given to Christians by contact with many strains of serious thinking in the environment of the Græco-Roman world.

One result of this contact, far-reaching in its importance, is seen in the Council of Nicæa (325 A.D.) and the creed by which that Council is now chiefly remembered. In regard to that creed two views are held: (I) that the contact of the Christian 


\section{The Christ of Faith}

Society with Greek thought during more than two centuries served only to make explicit what was implicit from the beginning in the two Christian convictions referred to; (2) that, while the creed does give expression to these convictions, the form in which they are expressed is due to metaphysical speculations about God and His relation to the world, which were current in the religious philosophy of the Greeks. The question here raised is a question for historical science to deal with, but it is a question which has a profound bearing on some of our present problems as to the interpretation of Christianity.

There was a special reason why the more educated members of the Christian Society should have been attracted by the Greek philosophy with which they could not avoid coming into contact. In its various forms and combinations of Stoicism and Platonism it was more than a philosophy; it was a working religion for many Gentiles, on whom the popular religions had lost their hold. Christians recognised that to such Gentiles they might make a successful appeal on behalf of their Lord. They were interested, therefore, in discovering points of affinity between Christianity and Greek philosophy. So close did the affinity seem, that they spoke of philosophy being a divine gift to the

I The most illuminating treatment of the subject is Hatch's volume-a pioneer -on The Influence of Greek Ideas and Usages upon the Cbristian Cburch. 


\section{Orthodoxy}

Greeks, as the law had been to the Jews, and mooted the question whether Plato and other Greek philosophers had not borrowed their noble thoughts from the teachers of Israel. Some of the most eminent Christians of the second century, such as Justin Martyr and Clement of Alexandria, had been trained in the schools of Greek philosophy, and became Christians because they found in Christianity a deeper satisfaction for their religious aspirations than their philosophy had given them. So, more and more the leadership of the Christian Society passed into the hands of Christians who were not only attracted by Greek philosophy, but knew it from the inside and were steeped in its conceptions and methods.

From the time of Justin Martyr in the middle of the second century to the Council of Nicæa in 325 A.D., a prominent feature of the Christian Society was the intellectual activity which was called forth by this effort to relate the Christian faith to the thought-world of the time. The Christian thinkers of these centuries rendered a service to the understanding and development of Christianity, which is perhaps more justly appreciated to-day than at any other period in the history of Western Christendom. Making use of the categories of contemporary philosophy for the fuller expression of their own Christian convictions, they have thrown helpful light on such themes as these-in which Christians have a 


\section{The Christ of Faith}

perennial interest : the immanence of God in the world and in the heart of man ; the affinity of God with man, and of man with God; the relation of Christ the incarnate Logos to all truth and beauty and goodness in the created universe; the unity of humanity in Christ; the divine education of the human race. Such eminent service it is fitting to recognise, when we have to take account of a particular direction in which the contact of Christian thinkers with Greek philosophy has had a certain harmful influence on Christianity, which has made itself felt all through the centuries down to the present day.

What we are here concerned with is the bearing of Greek philosophy on the formulation of the Nicene creed, and on the use which was made of this creed.

To understand this, it is necessary to have in view the conceptions of God current in the philosophical circles to which Christian thinkers were specially attracted. As has been said in chapter xiv., and may be here repeated for the convenience of the reader, Greek philosophy, seeking for such an explanation of the perplexing multiplicity in the universe as would satisfy intellectual needs, tended to find this in the conception of God as the Existent or Absolute, of whom nothing could be predicated, except His mere existence: to say, for example, 


\section{Orthodoxy}

that God loved, would involve a relation to the object of His love, and $\mathrm{He}$ would thereby cease to be the Absolute. God as the mere Existent-this was the outcome of the search for God by means of intellectual processes. But, then, here was the finite world, for whose explanation God as the Existent was postulated. How did the finite world come into being? Intermediaries between the existent and the finite world had to be requisitioned by the speculative imagination for the solution of the problem. Various were the ways in which the speculative imagination conceived such intermediaries. In the period with which we are concerned it was a favourite conception that the Existent, who could not come into direct contact with the finite world, did so indirectly through the Logos-at once the image of the Existent, and the ideal pattern as well as the creative power for the finite world.

It need hardly be said that this was not the conception of God which was cherished by Christians before they came into contact with Greek philosophy, or by which the majority of them were ever dominated. For the Christians, God was far more than what must be postulated for an explanation of the universe, satisfactory to the intellect. He was, above all, the God of the heart and conscience. He was present to them in the sanctuary of the heart, speaking to them without 


\section{The Christ of Faith}

noise of words, kindling visions of what they ought to be, demanding loyalty to these visions with inescapable authority, and working with them and in them for heartening in the moral struggle. For the Christians, God was love-fatherly, forgiving, suffering love, revealed in the teaching, life and Cross of their Lord.

These two conceptions of God seem to have little in common, to belong indeed to two different spheres. The Existent of Greek philosophy is God for the purely intellectual life; the God and Father of the Lord Jesus Christ is God for the ethical life. It has to be borne in mind, however, that the philosophers had other than intellectual interests ; they had their struggle for the realisation of ethical ideals, and in this sphere God was to them more than the Existent, transcendent and unknowable. On the other hand, Christians were not devoid of interest in the intellectual solution of the riddle of this mysterious world, and in this sphere, if they entered it, were fain to confess that God was beyond their power of comprehension, unsearchable, elusive, past finding out. Thus there were links between the philosophers and the Christians.

For two hundred years before the Council of Nicæa Christian thinkers were occupied with questions involved in these two divergent conceptions of God. Many Christians, even in Alexandria, the chief seat of theological speculation, 


\section{Orthodoxy}

fought shy of fraternisation with the religious philosophy of the Greeks. "The multitude," says Clement of Alexandria, "are frightened at the Hellenic philosophy, as children are at masks, being afraid lest it may lead them astray." But the fraternisation went on apace. There was much vigorous and fruitful thinking, and let it be specially noted that if the anti-Nicene age has by its enrichment of Christian thought made the subsequent centuries its debtor, part of the credit must be set down to the freedom which was given in these two centuries to Christian thinkers in their efforts to relate the Christian faith to the thought-world of their day.

At the Council of Nicæa the Christian Society may be said to have " taken stock" of these efforts. There were acute differences of opinion represented by the members of the Council (mostly bishops), especially as to how the Person of Christ was to be interpreted-all the different parties making use of the categories of Greek philosophy. The opinions of the majority were formulated in the Nicene creed, ${ }^{2}$ and received the sanction of the Emperor Constantine, as representative of the civil government. As between the Athanasians and the Arians, the majority gave expression to the vital

I Miscellanies, VI, 10.

2 The creed as drawn up at Nicæa was amplified to its present form at a somewhat later date. 


\section{The Christ of Faith}

Christian conviction that the God with whom Christians have to do is God in Christ. But the form in which they expressed that conviction was due to the influence of Greek metaphysics. It is said that this form only made explicit what was all along implicit in "the faith once delivered to the saints," "the deposit of faith." Whatever may be the exact meaning of "faith" in these phrases, it seems a bold assertion that there is implicit in it the formulated statement in the creed about the Lord Jesus Christ as "Begotten of the Father before all worlds, God of God, Light of Light, Very God of very God, Begotten, not made, Being of one substance with the Father." So far from being only a fuller explication of the original Christian faith, these clauses are derived from metaphysical speculations about the relation of the Logos to God conceived as the Existent, and can indeed only be duly intelligible in the light of these speculations. These clauses were full of meaning for the framers of the creed, who lived in an intellectual atmosphere impregnated with such speculations, and it may be granted that they expressed the Christian conviction about God as God in Christ, in the form most suitable to the circumstances of the Nicene age.

But however rightly the majority of the Council may have decided the question in debate between the Athanasians and the Arians, account has to be 


\section{Orthodoxy}

taken of the use to which their formulated creed was put. The controversy between the opposing parties was not ended by the decisions of the Council; it was carried on for long years with great bitterness, and disturbed the political as well as the ecclesiastical life of the empire. By the party which triumphed at the council assent to the creed was regarded as a test of genuine Christianity. Under the stress of controversy such assent tended to be reckoned as important as a Christ-inspired life, sometimes as even more important. This was in harmony with the genius of the religious philosophy of the Greeks, in which knowledge ( $\gamma \nu \hat{\omega} \sigma \iota s)$ of the mysteries of the Godhead and of the relation of God to the finite world had often a more commanding place than the doing of the will of God.

Emphasis on the necessity, for the Christian, of the right kind of speculative doctrine about God and the world was not a feature of the earliest Christianity; it found its way into Christianity from the environment of the Christian Society in later days. And it was attended with the serious risk of less emphasis being put upon the ethical side of the Christian religion. It is true, of course, that the ethical aspirations and attainments of Christians could not but be all-quick with convictions about God: any kind of true ethical life involves at least an implicit theology. But when intellectual assent to the theological doctrines- 


\section{The Christ of Faith}

including, in this case, the refinements imported from Greek metaphysics-which are implied in the ethical life is reckoned of almost equal importance with living out the ethical life, there is imminent danger of Greek intellectualism generating for the Christian Society, or at least for some of its members, a different atmosphere from that of the Sermon on the Mount.

There is another aspect of the handling of the Nicene creed, which deserves notice. There was a tendency to regard it as final and irrevocable-a tendency which increased in strength, the more the belief gained ground that the decisions arrived at by a majority of the members of a Council were inspired and sanctioned by the Holy Spirit, who was promised to the Christian Society to guide it into all truth. ${ }^{x}$ That did not merely mean that there were certain convictions about Christ and about God in Christ which were fundamental for Christianity; it meant that the peculiar form in which these convictions could alone be expressed was fixed once for all. The veto put upon its reconsideration had this for one of its consequences, that when the Christian faith found itself in contact with a different intellectual environment from that of the Nicene age, its defenders were hampered by the " dead hand"

I This is the pronouncement of the Council of Chalcedon ( $45 \mathrm{I}$ A.D.) on the Nicene Creed: It is unlawful to present, write, compose, devise, or teach to others, any other creed. 


\section{Orthodoxy}

in their task of interpreting it for their own generation as efficiently as the Nicene theologians had done for theirs.

It was in Eastern Christendom the Nicene theology had its hearth. Western theologians made their contribution, but it was mainly the creation of Christian thinkers in the East. It was there that the intellectual atmosphere existed with so potent a pressure as to make its creation possible. In Western Christendom, especially from the time of Augustine, there was a different atmosphere. Augustine had an extraordinary genius for metaphysical thinking, but it was not to the elaboration of speculative theology he chiefly devoted his great and varied powers. His interest was concentrated on the religious and ethical side of the Christian life -on man's sin and God's grace, on life in God, on faith and hope and love. Many of the features of current Christianity he accepted simply on the authority of the church, of which he became a baptised member in his thirty-third year. "I believe in many articles only on the Church's authority; nay, I believe in the Gospel itself merely on that ground." I Accepting the Nicene theology in this spirit, he did his best to bring it into harmony with Christianity, interpreted in the light of his own deep experience. "It has been

I Harnack, History of Dogma, V, p. 80. 


\section{The Christ of Faith}

said of Socrates that he brought philosophy down from heaven ; we may say of Augustine that he did the same for dogmatics, by separating it from speculations about the finite and infinite, God the Logos and the creature . . . and connecting it with questions as to moral good, freedom, sin, and blessedness. . . . In the new cathedral erected by him, the old building formed, as it were, the holy of holies which is seldom entered."I

Such unquestioning acceptance of the dogmatic theology elaborated in Eastern Christendom became more pronounced after Augustine's time. The Christian thinkers of the West were not at home in the metaphysical speculations by which that theology was deeply influenced. They took over the Nicene and kindred theology on the authority of the church. It was not to them, as it had been to Eastern theologians, a reasoned explanation of what was involved in Christian experience. It was a statement of mysteries, which had simply to be accepted. They treated it with jealous reverence as the divine revelation graciously given by Christ through His apostles to the guardianship of the Christian Society-a divine revelation, which, though not contrary to reason, was yet above reason.

So they brought into prominence the problem of the relation of revelation to reason, which was

I Harnack, History of Dogma, V, p. 95. 


\section{Orthodoxy}

destined to trouble Christian thinkers for many long centuries. But in thus regarding revelation as the communication of guaranteed doctrines about the mysteries of the Godhead and the Person of Christ, has there not been a departure from the conception of revelation we find in original Christianity ? To the early Christians revelation was far less a communication of doctrines about God than an actual unveiling of the heart and will of God Himself in Jesus, the Son of the Father-in the personality of Jesus manifested in His words and life and death. "He that hath seen me hath seen the Father" - that was how the early Christians interpreted the divine revelation. Through that revelation of God in Jesus there came to them a great experience. To give an intelligible explanation of that experience to themselves and to others, they could not well dispense with doctrinal statements of some sort. But it was their Christian experience, deriving from the revelation of God in Jesus, which was the origin of their doctrines-not the doctrines which were the origin of their Christian experience.

It would seem, then, that in conceiving revelation as essentially a supernatural communication of infallible doctrines about the mysteries of the Godhead and the Person of Christ there has been a side-tracking of Christianity. 


\section{The Christ of Faith}

The use to which the system of " revealed" doctrine was put from the early Middle Ages onwards is illustrated by the so-called Athanasian creed. ${ }^{\mathbf{x}}$ The tendency of the Nicene theologians to magnify the importance of intellectual assent to " orthodox" doctrine is here seen in full play. "Whosoever will be saved : before all things it is necessary to hold the Catholic Faith. Which Faith except everyone do keep whole and undefiled: without doubt he shall perish everlastingly." So the creed begins. Then follows a declaration of what the Catholic Faith is-a long list of statements about the mysteries of the Godhead and the Person of Christ, and scarcely anything else. Before all tbings assent to this list of statements is a necessary condition of salvation. There is a strange silence in this exposition of the Catholic Faith about a Christinspired life having something to do with salvation. ${ }^{2}$ Theological or rather metaphysical intellectualism has pushed into the background both the ethical and the religious side of the Christian religion. It may be pleaded that true thoughts of the Godhead and of Christ are essential to a true religious and

I There is uncertainty as to when and where this creed originated. The one thing certain is that it was not drawn up by Athanasius. The first part of the creed is based on the decisions of the Council of Nicæa ; the second part which deals with the Person of Christ as "two natures in one person" is based on the decisions of the Council of Chalcedon (45I A.D.), which do not harmonise well with the characteristic theology of Eastern Christendom.

2 In the concluding sentence there is a general reference to the last judgment. 


\section{Orthodoxy}

ethical life. Let that be granted, but it does not follow that such true thoughts are ensured by an intellectual assent to theological speculations. And what this magnifying of "orthodoxy" at the expense of the Christ-inspired life may mean is written in lurid characters in the long and tragic story of the inhumanities inflicted by Christians upon fellow-Christians in their zeal to instil into men a dread of heresy and keep them true to that orthodox Catholic faith from which, if they depart, they shall without doubt perish everlastingly.

For the indispensableness of assent to such theological doctrines about the Godhead and the Person of Christ as seem to bear the marks of the reaction of Greek philosophy upon Christian thinking, the authority of Christ and His apostles is claimed. But how does this harmonise with the ideals of the Jesus of history? In answer to that question, attention may be directed to one or two features of His life and teaching.

In Greek philosophy the conception of God is arrived at by intellectual processes. In the teaching of Jesus we are in a different atmosphere. Here God is immediately present to the heart and conscience. Here God is not proved; $\mathrm{He}$ is experienced. In this sphere the important question is not, What is God as the ultimate ground of all things ? but, What is God to me in my ethical and 


\section{The Christ of Faith}

religious life ? that is, What is God's heart towards me, His will concerning me? It is with such questions Jesus is concerned: His revelation of God centres in the revelation of the heart and will of His Father in heaven towards His children.

Jesus was conscious of a unique relation to God, and a unique vocation by God, and $\mathrm{He}$ made a unique claim for loyalty to Himself. But it is significant that it was towards the close of $\mathrm{His}$ ministry $\mathrm{He}$ put the question to the disciples: "Who say ye that I am ?" (Mark viii. 29). He had taught them in His close companionship with them how $\mathrm{He}$ interpreted the Kingdom of God and His leadership in it. What $\mathrm{He}$ was concerned with was their response to His ideals, so startlingly novel. It was only when $\mathrm{He}$ found in them a sufficiently loyal response that $\mathrm{He}$ could rejoice in their confession: Thou art the Christ. He cared not for the acknowledgment of His Messiahship, apart from loyalty to His ideals of the Kingdom of God; apart from loyalty to what $\mathrm{He}$ stood for. Does not this indicate that the spiritual life which is inspired by Jesus takes precedence of assent to doctrines about His Person?

When such creeds as the Nicene and the Athanasian are so handled as to create-illegitimately it may be-an impression that assent to their theological doctrines about the Person of Christ is more fundamental for Christian discipleship than 


\section{Orthodoxy}

living the Christ-life, it may be well to recall the Master's own words: "Not every one that saith unto me, Lord, Lord, shall enter into the kingdom of heaven; but he that doeth the will of my Father which is in heaven " (Matt. vii. 2I). 


\section{CHAPTER XX}

\section{Epilogue}

IN speaking of the impress which the personality of Jesus has made upon the life of Christendom, Emerson says that His name is not so much written as "ploughed into the history of the world." To the same effect W. E. H. Lecky says : "It was reserved for Christianity to present to the world an ideal character, which through all the changes of eighteen centuries has inspired the hearts of men with an impassioned love; has shown itself capable of acting on all ages, nations, temperaments and conditions; has been not only the highest pattern of virtue, but the strongest incentive to its practice; and has exercised so deep an influence that it may be said that the simple record of three short years of active life has done more to regenerate and soften mankind than all the disquisitions of philosophers, and all the exhortations of moralists."

In our inquiry into the relation of the Jesus of history to the Christ of faith it has been constantly

I Life of Emerson, by Holmes, p. I 20.

2 History of European Morals, II, p. 8. 


\section{Epilogue}

borne in upon us that the personality of Jesus-the miracle of miracles-has been the dominant factor in the development of Christianity. We have had occasion to take note of shortcomings and aberrations. Within the Christian Society, in all its branches and in all the centuries, there has been a tendency to let the personality of Jesus be pushed into the background by a disproportionate engrossment with forms, whose only legitimate function is to be a channel for the outgoing of the power of that personality. As Tennyson has somewhere said with reference to this magnifying of forms over that which they are meant to subserve: "The churches have buried their Christ." But through all the centuries the "buried" Christ has been ever coming to life again. $\mathrm{He}$ "is always there, to quicken the churches, to make them distrust their own rules, to inspire new saints." "Back to Christ" is no mere cry of our own age; it has been heard in every age, and heard to purpose.

Since the earlier half of the nineteenth century there has been a steadily strengthening tendency to go back to the Jesus of history, and to examine current conceptions of Christianity in the light of His ideals. In the sphere of theological thinking Schleiermacher, brought up in the atmosphere of Moravian piety, laid the whole stress on the

I Clutton-Brock. 


\section{The Christ of Faith}

personality of Jesus, and has influenced Christian thought for the last hundred years more powerfully than any theologian since the days of John Calvin. Speaking of the early growth of the Tractarian movement, which was taking shape before Schleiermacher's death (1834), Dean Church, who was sympathetic towards its nobler aspects, tells us that one of the characteristics was "the increased care for the Gospels." "Evangelical theology had dwelt upon the work of Christ, and laid comparatively little stress on His example, on the picture left us by His Personality and Life. It regarded the Epistles of St. Paul as the last word of the Gospel message. People who can recall the popular teaching, which was spoken of then as 'sound,' and 'faithful,' and 'preaching Christ,' can remember how the Epistles were ransacked for texts to prove the 'sufficiency of Scripture,' or the 'right of private judgment,' or the distinction between justification and sanctification, while the Gospel narrative was imperfectly studied, and felt to be much less interesting. The movement made a great change. The great Name stood no longer for an abstract symbol of doctrine, but for a living Master, who could teach as well as save. And not forgetting whither $\mathrm{He}$ had gone, and what $\mathrm{He}$ was, the readers of Scripture now sought Him eagerly in those sacred records, where we can almost see and hear His going in and out among men. It was a change in the look and use 


\section{Epilogue}

of Scripture, which some can still look back to as an epoch in their religious history."

Since those days in the fourth decade of last century, to which Dean Church here refers, interest in the Jesus of history has been broadening and deepening, as is evidenced by the innumerable books which have been written, and are still being written, on the life and teaching and personality of Jesus. No efforts have been spared to turn the resources of scholarship and history to account for lighting up the environment in which He lived, and Christian thinkers have striven to bring out the spiritual significance of the life $\mathrm{He}$ lived and of the lessons He taught. The Jesus of history, it is not too much to say, is better known to-day than in most of the past Christian centuries; true though it be that love is ever the master key for the understanding of "the infinite nature of Christ." And this increase of interest in the Jesus of history has tended towards laying a new emphasis on His ideals as regulative for the thought and activity of the Christian Society, which regards itself as His creation ; towards assigning to His ideals a more commanding place in answering the question: "What is Christianity?

Even in the Church of Rome, voices, crying in the wilderness they may have been, have been heard in recent years appealing to the Church to go

I The Oxford Movement, p. 191, 3rd ed. 


\section{The Christ of Faith}

back to the Jesus of history. "Back to Christ," says Father Tyrrell, "back to the Gospels that is, to the classical and normative manifestation of that spirit by which all other spirits have to be tested and criticised . . . We judge the lives of ordinary Christians by Christian teaching; but when this teaching is itself in question, we test it by the admitted or classical standards of Christian life ; we turn to Christ, whose life is, in a sense, a divine revelation, an implicit depositum fidei." " "We desire," said the Italian Modernist, Dom Romolo Murri, " a Christianity more pure, more intense, more practical, more Christian, more conformed to its original, more conformed to the Gospels." And Fogazzaro puts these words into the mouth of "The Saint," speaking in presence of the Pope: "Though they hurl vituperation and thunderbolts against me, not until the hour of my death will I cease crying aloud: What will Christ say? What will Christ say? To Him I appeal." Such was the appeal of Modernism, at least of some of its representatives, but the Pope and his counsellors were well aware that the admission of their appeal, as interpreted by those who made it, would issue eventually in the breaking up of the Church of Rome, as at present organised.

In going back to the Jesus of history as the supreme standard for the interpretation of

I Lex Credendi, pp. 20, 3. 


\section{Epilogue}

Christianity, we are in the line of a long and inspiring succession. Here has been one secret of the perennial renascence of Christian life and thought. In this direction may we not look for a similar renascence in our own day?

It lies outside the scope of this volume to discuss at length what is involved in such a renascence, but in these closing pages it may not be out of place to indicate, more explicitly than has been already done, how the ideals of Jesus seem to bear upon one or two subjects which have a special interest for many of the thoughtful men and women of the present generation.

I. What place is to be assigned to goodness in the religious life?

The study of the teaching of Jesus as recorded in the Sermon on the Mount and elsewhere in the Gospels, and especially of His trenchant and oftrepeated criticism of the religious ideals and usages with which $\mathrm{He}$ found Himself in contact, suggests that in His interpretation of religion $\mathrm{He}$ assigned to goodness of life, not only an important, but the sovereign place. "Seek ye first his kindgom and his righteousness" (Matt. vi. 33) -that is a note which is struck again and again in His sayings and in His own life. Goodness, according to Jesus, is the supreme human interest ; it is man's "chief 


\section{The Christ of Faith}

end "; it is the goal of God's purpose with man. The goodness, which is the constantly recurring theme of His teaching, is " more than others" have in view when they extol virtue and press for its practice. It transcends accepted rules for correct moral conduct; it wells up from the depths of a "good heart"; it is the outcome of an inspiration of love like His own and has its issue in a life, like His own, of heroism and self-sacrificing service.

In connection with goodness of this sort Jesus has a place for repentance and for faith in Himself. He calls men to repentance, to a change of mind; to a change of mind about the absolute worth of goodness in comparison with the abundance of the things which a man possesseth (Luke xii. I 5); to a change of mind about success in life ("Whosoever shall lose his life for my sake shall find it "Matt. xvi. 25); to a change of mind about riches ("How hardly shall they that have riches enter into the kingdom of God!" Mark x. 23); to a change of mind about true greatness ("Whosoever would be first among you shall be servant of all "Mark x. 44). And He demands devotion to Himself, and devotion of a quite exceptional kind, but He has no use for a devotion to Himself apart from devotion to the ideals of goodness set forth in His life and teaching. "Why call ye me, Lord, Lord, and do not the things which I say?" (Luke vi. 46). 


\section{Epilogue}

The neglect of this insistence by Jesus upon the sovereignty of goodness has had disastrous effects within the Christian Society all through its history. It has given its point to most of the criticism which has been directed against the churches. It has obtained in the Protestant churches as well as elsewhere. Archdeacon Paley, whose writings had a profound influence for more than a hundred years upon the theological thought of England, defined virtue as " the doing good to mankind, in obedience to the will of God, and for the sake of everlasting happiness." By way of explaining what he means, he gives this as an illustration: "Let it be asked, why am I obliged to keep my word? and the answer will be, Because I am urged to do so by a violent motive (namely, the expectation of being rewarded after this life, if I do, or punished for it, if I do not)." That means that the supreme interest is centred in pleasure and pain. Goodness is not man's chief end ; it is a means to an end beyond, and greater than itself-escape from the painful consequences of $\sin$ in hell, and enjoyment of never-ending happiness in heaven. Against such a dethronement of goodness from its sovereign place many who have sat at the feet of Jesus would find a fitting protest expressed for them in the mediæval story of the woman, who, when asked what she was to do with the pan of fire she carried in her right hand, and with

I Moral and Political Pbilosopby, Bk. I, chap. vii.; Bk. II, chap iii. 


\section{The Christ of Faith}

the pitcher of water in her left, replied : "To burn up paradise and to quench the fires of hell, that men might be good for the love of God and goodness alone."

When the strongest motive for striving after goodness is represented as escape from pain and enjoyment of pleasure, it follows not unnaturally that the average Christian is encouraged to be content with average goodness. Select souls, supposed to be peculiarly constituted, may be admired for guiding their lives by the "counsels of perfection." They are aiming at the Honours degree, while an ordinary Pass is sufficient for "salvation." So it happens that the claim Jesus makes upon every follower of His is somewhat ignored; with the result that many professing Christians, presuming that they are securing their "salvation" by correct moral conduct, orthodox beliefs about Christ and due attention to the Church and its ordinances, go the world's way in their daily life, not heedless indeed of the restraints dictated by a prudential regard for public opinion, but somewhat heedless of the demand of Jesus that they do "more than others" in the handling of wealth, in seeking after greatness, and in readiness, for the sake of worthy ends, to renounce pleasure and comfort, and to accept pain and loss.

Christianity, if it is presented as, on the one hand, demanding no more than conventional virtue 


\section{Epilogue}

and, on the other hand, as "set to the gauge of personal gain, as a way of booking a reserved seat in heaven," fails to appeal to what is deepest and noblest in the human soul. "Mankind's common instinct for reality," says William James, " has always held the world to be essentially a theatre for heroism. In heroism, we feel, life's supreme mystery is hidden." "The world," he says elsewhere, " finds in the heroic man its worthy match and mate; and the effort which he is able to put forth to hold himself erect and keep his heart unshaken is the direct measure of his worth and function in human life. $\mathrm{He}$ can stand this Universe. He can meet it and keep up his faith in it in presence of those same features which lay his weaker brethren low. . . . And hereby he becomes one of the masters and the lords of life."3

Heroic goodness, and heroic goodness sought after for its own sake and not merely for the sake of everlasting happiness-it is for that a demand must be made in the appeal on behalf of Christianity. Newman, who was well aware of " a higher class of motives which will be felt by the saints," yet assumes that the ordinary Christian must be appealed to on a lower plane for "strenuous effort and persevering toil." "It is in vain," he says, " to look out for

I So a young officer in the British Army in France wrote of a prevalent conception of Christianity among the soldiers.

2 Tbe Varieties of Religious Experience, p. 364.

3 Psycbology, II, chapter on the Will. 


\section{The Christ of Faith}

missionaries for China or Africa, or evangelists for our great towns, or Christian attendants on the sick, or teachers of the ignorant, on sucb a scale of numbers as the need requires, without the doctrine of Purgatory."

Surely Carlyle comes nearer to the mind of Jesus about what is possible to man. "It is not to taste sweet things, but to do noble and true things, and vindicate himself under God's heaven as a Godmade man, that the poorest son of Adam dimly longs. Show him the way of doing that, the dullest day-drudge kindles into a hero. They wrong man greatly who say he is to be seduced by ease. Difficulty, abnegation, martyrdom, death are the allurements which act on the heart of man. Kindle the inner genial life of him, you have a flame that burns up all lower considerations. Not happiness but something higher. . . . Not by flattering our appetites; no, by awakening the heroic that slumbers in every heart, can any religion gain followers.",

The sovereignty of goodness for its own sake is at the heart of the teaching of Jesus; it is at the heart of His life and of His Cross; it is at the heart of the life of those who are "crucified with Christ." But does this not mean an undue magnifying of the

I Essay on Development, p. 423. (The italics are my own.)

2 Lectures on Heroes, II. 


\section{Epilogue}

ethical over the religious life? No ; it is precisely in the struggle after such goodness we most surely find God, and learn what God means for us. The inward voice which rings out the call for heroic action-that is the voice of God. The "upward urge of the heart" which impels us towards the heights-that is the pressure of God. The incentives which crowd in upon the conscience in the hour of crisis, to back up our weak will, to give victory to the higher self over the lower-that is the grace of God. In the moral struggle we have not merely a belief about God; we have an experience of God. We are as sure of God, as we are of conscience. If we do not thus find Him first within, we shall never find Him without, be the intellectual proofs addressed to us what they may. As Newman has put it: "Were it not for this voice, speaking so clearly in my conscience and my heart, I should be an atheist, or a pantheist, or a polytheist, when I looked into the world." ${ }^{\prime}$

2. The Revelation of God in Jesus.

The " acknowledgment of God in Christ" is bound up with Christianity. Take away this conception of God, you may have religion left, but not the Christian religion; you may have worship left, but not Christian worship; you may have worthy ethical ideals left, but not the Christian ideals. The

$$
\text { I Apologia, p. 241. Ed. } 1875 \text {. }
$$




\section{The Christ of Faith}

God with whom Christians have to do is not the God found by the metaphysician in his intellectual search for the ultimate ground of the universe-the Absolute, or the Great All, or the First Cause, or the Creator and Governor of the finite world. God in Christ is, above all, the God of conscience, "closer than breathing, nearer than hands and feet," who is at the heart of ethical as well as of religious experience, at once the ideal and the inspirer of goodness.

That God is God in Christ is a fundamental Christian conviction. It has been an inspiring and transforming force all through the long and chequered history of Christianity. It goes back to the Apostles. It derives from the Master who said of Himself: "Neither doth any know the Father, save the Son" (Matt. xi. 27). As has been indicated in chapter xv., it has been receiving in recent years fresh expression in widely varied form. One of the most notable of such expressions has been given by Dr. Denney in the closing pages of a singularly weighty volume. "It only remains to ask," so may the exposition of his conviction be summarised in his own words, "whether we can put the religious truth about Jesus, the significance which $\mathrm{He}$ has for the faith of Christians, into words which all who adopt the Christian attitude to Him would recognise as the expression of their faith." And this is the answer he gives: "It is perhaps not too bold to suggest that the symbol of the church's unity 


\section{Epilogue}

might be expressed thus : I believe in God through Jesus Christ His only Son, our Lord and Saviour."

This fundamental Christian conviction finds expression in the Nicene creed (and in other doctrinal creeds, such as the Westminster Confession of Faith, which derive from Nicæa). This accounts for the reverent esteem in which it has been held. But the peculiar form in which the conviction is expressed gives rise to questionings. Historical science is making it increasingly evident that the framers of the Nicene creed were dominated in their theological thinking by the metaphysical and cosmological categories of the Greek philosophy with which the Christianity of the early centuries was brought into close contact. Such a use of contemporary philosophy may have been serviceable for Christianity in the fourth century. But it had its drawbacks. It made it difficult in that age, it has made it difficult down to our own day, to maintain the true humanity of Jesus. And it has made it easy for Christian thought to tend towards what is virtually Ditheism, to divide " the functions of the Deity between the Father and the Son, conceived practically as two distinct personalities or centres of consciousness."

I Fesus and the Gospel, pp. 397-8. In an admirable little volume, not too well known in this country, there is a similar expression of this fundamental Christian conviction in the closing paragraph: "We believe in God, the Father of our Lord Jesus Christ, and through Him, our lather too." Cbristologie seit Scbleiermacber, by Dr. S. Faut, p. 102. 


\section{The Christ of Faith}

The phrases of the Nicene creed describing the Person of Christ, even if, or because, no very definite meaning is attached to them, may leave upon many worshippers an impression like that of solemn music. But there are a considerable number of people, fervent in their whole-hearted acknowledgment of Jesus as Lord, for whom they are a stumbling blocka stumbling block which acts as an inhibition upon enthusiastic co-operation in the activities of the Church, and which deprives the Church of officebearers and ministers whose services can ill be spared in these difficult times. Is it too much to hope for, that the churches with their widespread desire to deal adequately with the needs of the time will have courage to reconsider their attitude to the Nicene theology, to consider, especially, whether the safeguarding of the fundamental conviction about God as God in Christ is necessarily bound up with the acceptance of the particular form in which this conviction was expressed in an age whose intellectual environment was so different from that of our own?

This does not by any means imply that it was wasted effort on the part of early Christian thinkers to do their best to relate the conception of God in Christ to the thought-world in which they lived. Their work was immensely fruitful, not only in commending Christianity to Gentiles who had been educated in the atmosphere of Greek philosophy, 


\section{Epilogue}

but in giving the Christian Society a fuller understanding of the far-reaching significance of the Christian faith. What those early Christian thinkers did for their time needs to be done for our time, not indeed by every Christian, but by those who are specially equipped for the task, and whose position in the Church lays upon them a special responsibility for undertaking it. The correlation of the conception of God in Christ to the modern conception of evolution is an example of the many problems which the Christian thinkers of our day are called upon to deal with. The fruitful exercise of their intelligence upon such problems implies freedom; in this case freedom from bondage to the metaphysical and cosmological categories of an ancient philosophy. Else the "dead hand" of the past may fall "with a resounding thud upon the living thought of to-day."

As to the use to which the Church may put the results of the exercise of Christian thinking upon the relation of the conception of God in Christ to the modern intellectual environment, the Council of Nicæa offers a warning rather than an example. To embody the substance of these results, by a majority vote of church Council or Assembly, in some such simplified creed, as is contemplated by not a few who are interesting themselves in credal reform, and to demand assent to this creed as a condition of holding office in the Church-would 


\section{The Christ of Faith}

there be no risk here of putting, to some extent at least, a closure upon the renewal of Christian thinking, and of hampering future generations with the fatal legacy of the " dead hand "? Further, to incorporate into a creed, which is to be recited in public worship or used as a test for holding office in the Church, an intellectually satisfactory statement of the relation of the conception of God in Christ to modern thought is to do what the Nicene theologians did, with unhappy consequences for Christendom. It is to put the emphasis in the wrong place. "A Christian man's business," said Zwingli, " is not to talk grandly about dogmas, but to be always doing arduous and great things in fellowship with God." I It may be importantit is important-for Christians to have as full an understanding as is possible for them in their varying circumstances of the bearing of their Christian faith upon the thought-world in which they find themselves. But to own Jesus as the Lord of life, to be mastered by His ideals, and to throw oneself with the whole heart and the whole strength into the great enterprise for humanity, of which $\mathrm{He}$ is the Leader-it is on that the emphasis is laid by the Apostles and by the Master Himself ; and anything which imperils the maintenance of that emphasis tends to be a side-tracking of Christianity.

I Quoted by Harnack, History of Dogma, VII, p. 274. 


\section{Epilogue}

3. The Kingdom of God.

"Dig within" says Marcus Aurelius. "Within is the fountain of good." With that as the text for his meditations he has many noble things to say about caring more for the "inner self " ${ }^{2}$ than for the outward circumstances of one's lot. But with the Stoics, who were the Emperor's chief teachers, there was a tendency to lay one-sided emphasis upon absorption with the inner life of the independent individual soul. With Jesus the inner life is everything, but an inner life, of which the distinctive feature is not the moral strength of the self-centred individual, but a heroic love for others. And on the religious as well as the ethical plane Jesus leads us out from a narrow, if in itself a worthy, individualism, into the wider life we live in and with our fellows. "God and the soul, the soul and its God "- that is the watchword of the religious life. But here too, there may be a one-sided emphasis on mere individualism. This too readily happens, when God is conceived as merely the Infinite, in sinking back on whom the finite individual finds rest and true life. Jesus calls us indeed to a very intimate fellowship, a fellowship as intimate as His own, with God, but to a fellowship with God which is most surely fostered through fellowship with the children of the one Father of all. The Fatherhood of God leads us beyond individualism in the religious

$$
\text { I VII, 59. }
$$$$
2 \text { II, } 2 .
$$ 


\section{The Christ of Faith}

sphere, as the supremacy of love does in the ethical sphere.

It is therefore in harmony with the emphasis Jesus put upon the Fatherhood of God and the supremacy of love that the Kingdom of God has the large place in His teaching, which has recently been receiving juster recognition. The Kingdom of God is one of His regnant thoughts, as much as that of the Fatherhood of God, or of the supremacy of love ; as regnant and as fruitful. The Kingdom of of God is His vision of ideal society. In comparison with others who have had their generous dreams of what the social life of man might be, He has little to say about the outward forms it will assume. What $\mathrm{He}$ concentrates attention upon-and here we have another witness to the uniqueness of His insight-is the spiritual life on which ideal society, if it is to be realised, must rest. "The kingdom of God is within you "(Luke xvii. 2I)—these words, even if they be not the correct translation of the Greek, are the expression of His mind. We find that in speaking of the Kingdom of God He has often not a word to say about anything but the spiritual temper which is necessary. For example, "The kingdom of heaven is like unto a man that is a merchant seeking goodly pearls : and having found one pearl of great price, he went and sold all that he had, and bought it " (Matt. xiii. 45). He may have more sympathy with the dreams of the popular 


\section{Epilogue}

apocalypses than with those of the political zealots, and $\mathrm{He}$ may draw upon their imagery, with which His hearers were familiar, to express His thoughts, but His own vision of the Kingdom of God transcends the highest visions of the apocalyptic writers. It is not limited by the apocalyptic forms, or indeed by any other forms. Just because it is centred in the spiritual life which must be the real creator of any ideal society, it is universal, it has its bearing upon social life in all its aspects, upon the family, the community, the nation, the brotherhood of humanity; and just because the spiritual life, in which it is centred, is eternal life, it has its bearing beyond this "bank and shoal " of time.

The Kingdom of God, as interpreted by Jesus, is the noblest ideal for life's struggle-an ideal, which is "the everlasting real." It was the inspiration of His own life, of His thought and toil, of His suffering and Cross. And it has a mighty power of appeal to every one who is feeling out for something worth living for, and, if need be, worth dying for. There are heroic souls who cannot find this in their own ethical culture, or in their own individual "salvation." They are eager to give themselves to the furtherance of a great and worthy cause. Their temper is revealed in sayings like these: "So be it France is free, let my own name be blighted," "Who dies, if England live ?" or as St. Paul puts it with a passion that staggers the reader: "I could wish that I myself 


\section{The Christ of Faith}

were accursed from Christ, for my brethren, my kinsmen according to the flesh" (Rom. ix. 3). The Kingdom of God, or to use a suggestive phrase with which Professor Royce has made us familiar, "the beloved community" appeals to the heroic in man. In whatever sphere devotion to "the beloved community" may be called for-our home, our village, our country, or Christendom, or God's great human family-there is scope for the "sacrificial ardour of the sons of thunder."

"Jesus," says Loisy, " " announced the Kingdom, and it is the Church which has come." Whether the Kingdom can be thus roundly identified with the empirical Church may well be questioned. The church is indeed the chief organ for realising the Kingdom, but the Kingdom is wider than the Church. There are other organs by which the ideals of the Kingdom are to be realised, and serious loss is incurred when the Church depreciates the worth of these co-operative agencies in furthering the interests of the Kingdom. One unhappy result of the identification of the Kingdom with the Church has been the division of life into what is sacred, what is concerned with the things of the Church, and into what is secular, what is concerned with all that lies outside the sphere of the Church-as if the life of the home were not only an organ, but a chief organ for

I L'Evangile et l'Eglise, p. 155 . 


\section{Epilogue}

realising the ideals of the Kingdom; as if, in "the trivial round, the common task," in service to the community, the nation, and humanity we could not find scope for the "sacred" work of helping to bring in the Kingdom of God. It is at the Church's peril, and to the hurt of the Kingdom, if it loses the vision of a Kingdom of God wider than the Church. As family life, shut in upon its own narrow family interests, suffers inevitably from lack of cleansing and invigorating winds which blow from the spacious fields beyond the home, so the Church, shut in upon its own narrow ecclesiastical interests, cannot fail to breed tempers and foment frictions which are alien to the Kingdom of God.

The vigorous criticism to which the Church is being subjected to-day springs to a large extent from a conviction of the service which an institution, with so great a history and so great a present power, might render not only to the individual, but to the various forms of our communal life, from the family to the brotherhood of humanity.

The Church is being urgently called upon to help in the reconstruction of our social and industrial life, and the Church cannotwell be indifferent to the call. To interest itself in whatever bears upon the Christianising of human life in all its forms-that belongs to it as the chief organ for realising the ideals of the Kingdom of God. As far as the individual 


\section{The Christ of Faith}

members of the Church approach the problems of re-construction, inspired by the spirit of Jesus, by His faith in the Fatherhood of God and the brotherhood of man, by his estimate of riches, success and greatness, so far the Church is rendering a service which may sometimes be overlooked, but cannot well be overestimated. How far the Church, not merely through its individual members, but as a Church, is to be the champion of a special method of solving a particular social or industrial problem, that is a question which cannot wisely be answered by an appeal to some abstract principle. In any case, it would seem to be the wisdom of the Church to concentrate its chief attention upon those Christian ideals and tempers, without which re-construction in the mere framework of social and industrial life may prove in the long run to have produced but Dead Sea fruit.

There is, however, one direction in which the Church, without dealing directly with social and industrial problems for whose solution it may not have the necessary knowledge, may yet indirectly exercise a profound influence-some reconstruction by the Church of some of its own ideals and ways. The Church of the early centuries interfered but little with the existing social framework. Nevertheless it did immensely fruitful service to the reconstruction of social life. For one thing, it realised a true brotherhood in the Christian Society 


\section{Epilogue}

itself. Rich and poor, freeman and slave, master and servant, learned and unlearned met together, not merely as worshippers, but as brothers in Christ. Christians cared for their fellow Christians in poverty or sorrow or other distress with a self-sacrifice and assiduity which amazed non-Christian on-lookers. Such brotherliness worked as leaven beyond the limits of the Christian Society. It engendered a higher social spirit which by and by found expression in kindlier social customs and humaner laws. No one who has first-hand knowledge of modern church life will be disposed to deny that the Christian congregation is often a centre of warm social fellowship, and of brotherly helpfulness. But is it not significant that alongside of the conventional Sunday assembly there has sprung up the institution known as the Brotherhood? Does this not suggest some lack of brotherhood in ordinary church life ?

One special help for the development of brotherhood may be singled out. The more a Christian congregation realises for what, as an integral part of " the body of Christ," it exists, the stronger will be the sense of brotherhood among its members. A society of Christian men and women means a fellowship for the edification and spiritual comfort of its individual members. But it means more. It is a comradeship in the great enterprise of realising Christ's ideal of the Kingdom of God in human lifean enterprise which demands the exercise of the 


\section{The Christ of Faith}

special gift of each individual member, and whose success is largely conditioned by the measure in which the members work towards the common end in a spirit of brotherhood.

More comradeship inside the Church of Him who said: "All ye are brethren" (Matt. xxiii. 8) -that is one direction in which the Church can help in social and industrial reconstruction. When all classes, rich and poor, masters and workmen, have come, through their comradeship in the Christian Society, into more effective touch with each other's thought-world and each other's struggles, brotherhood will become what it was in the early centuries, one of the most distinctive " notes" of the Church of Christ-a brotherhood which will work as leaven beyond its own borders, and in the long run find expression in social and industrial arrangements more consonant with the genius of the Kingdom of God, as interpreted by Jesus.

If there is to-day a call to the Church to play its part in the reconstruction of our national life, no less urgent is the call for its service in furthering the interests of the Kingdom of God in the international sphere. The Kingdom of God is wide as the great family of the one Father of all. During these terrible years of international conflict there has been in many hearts a deepening conviction of the 


\section{Epilogue}

need of loyalty to the widest form of " the beloved community," of the need of loyalty to humanity. Selfish nationalism is the direct negation of the Christian ideal of the Kingdom of God. We have had a harrowing experience of the bitter fruits of such nationalism. And the poison is at work in many different quarters among ourselves. Loyalty to the Kingdom of God carries with it, indeed, love of one's country, eagerness to serve it, readiness, if need be, to die for it. But "patriotism is not enough." As Mazzini said, "Nationality is sacred to me because I see in it the instrument of labour for the good and progress of all men."

It belongs to the Christian Church to play a worthy part in realising that great ideal of the Kingdom of God which has been the inspiration of the widespread movement for the establishment of the League of Nations. "The spirit of good will among men," said the Premiers of the British Empire in their New Year's message of 1920, "rests on spiritual forces; the hope of a 'brotherhood of humanity' reposes on the deeper spiritual fact of the Fatherhood of God." The Church should be foremost in co-operating with all who are striving to bring spiritual forces to bear upon the solution of the problems of international life. There is one special direction in which she might render service. In mediæval Europe there was an international Christianity, which, whatever may have been its 


\section{The Christ of Faith}

failings, did exercise a beneficent influence amid the conflicts of contending nations. With a revival of international Christianity, in forms suitable to the circumstances in which the divided Church finds itself to-day, might there not come into the field a potent ally for achieving the noble aims of the League of Nations, and in the comradeship fostered by common service to the good of humanity, might there not be found an efficient means of drawing the churches into more fruitful sympathy with each other, and so infusing into the already existing unity of Christendom more reality, and greater power to minister to a distressed and distracted world ?

To-day there is a loud call in the name of humanity for the Church to give itself to the service of the Kingdom of God as interpreted in the light of the great vision that lived, yea, that burned and ever burns in the heart of the Leader. There are Christian men and women who look forward to the future of the Church not only with anxiety, which can never be out of place, but with that fear, born of faithlessness, which leads inevitably towards defeat. They are unnerved by the bewildering change which has taken place, and which shows no signs of having come to an end, in the sphere of religious thought. But change is not in itself a sign of decay. "To live is to change ; to be perfect is to have changed often." The Christ-inspired 


\section{Epilogue}

experience has been an abiding thing in the Christian Society, but from the apostolic age onwards there has been change in the doctrinal expression of this experience, and change in the form of worship, ministry and church government, which have been instruments for awakening and nourishing this experience. The mere fact of change is no good ground for a pessimistic outlook. There are "things that cannot be shaken." If only God can count upon loyal fellow workers, " the city of God remaineth." Sursum corda! We are the heirs of great traditions of service to the Kingdom of God, which come to us from all the centuries, and which encompass us as a cloud of witnesses, an innumerable company of hearteners. We can draw upon "a reservoir filled with the results of the spiritual strivings and triumphs of two thousand years." Great traditions are behind us, and great opportunities before us,

"The echoes of the past within [our] brain

The sunrise of the future on [our] face."

Not only inside the Church, but even outside it, there has been a deepening conviction that the wounds inflicted upon Christian civilisation by the soul-shaking, heart-breaking world-conflict, and the dangers threatening the social and industrial life of the whole world, constitute a challenge to the Christian Church to match the gravity of

I Percy Gardner, Evolution in Cbristian Doctrine, p. 217. 


\section{The Christ of Faith}

the situation with the requisite will-force. It is a mighty task. But here is the opportunity for what is supposed in many quarters to be a decadent Church to prove that its loyalty to the ideals of Jesus, not only in its own church life, but in all the wide fields of the life of humanity, is strong enough to bring healing and hope to a stricken world. This is no time to be content with bewailing the sins and follies which have brought unparalleled suffering and sorrow upon the human race. It is a time to hear the call of the Leader in the Kingdom of God, and to answer with the stern joy of " the happy warrior" :

"Now, God be thankéd Who has matched us with His hour."

In co-operation for carrying through the mighty task which is laid upon the Church the cause of Christian unity is involved. Loyalty to that branch of the Christian Society which has been our nursing mother-not necessarily a blind acceptance of all its conventional thoughts and ways, but loyalty to what we believe to be its true and better mindthat is the starting point. Such loyalty to "the little platoon" leads us inevitably towards comradeship with all who are throwing themselves into the Christ-inspired and Christ-led enterprise of bringing in the Kingdom of God. What distinguishes our own branch of the Christian Society from other branches may be important enough in its 


\section{Epilogue}

due place, but if the place we give it is proving a hindrance rather than a help to the common enterprise of the Christian Society, we may well ask whether our loyalty to the Kingdom of God is not being impaired by a possibly exaggerated emphasis upon some special forms in which Christ-inspired experience has found expression. Be that as it may, if the Christian Church in all its branches responds to the present urgent call for heroic loyalty to the Kingdom of God, "the expulsive power of a new affection" will make an end of some at least of the worst evils of sectarianism. We may look forward to the day when comradeship, born of heroic loyalty to the service of humanity, may find expression in the union of churches. But the real unity of the Christian Society is not to be found in the framework of one ecclesiastical organisation. It is to be found in the one Christ-inspired life of those who own Jesus as Lord, and in the comradeship of "fellow-workers with God, fellow combatants in the strife" for realising that vision of ideal society for which Jesus lived and died and lives for evermore. To care for such " unity of the spirit" may be the wisest way to work for curing the ills of a divided Christendom. 



\section{Index}

Apocalypses, 32

Apology of Aristides, 142

Arius, 155

Arnold, M., 101

Athanasian Creed, 212, 214

Athanasius, 155

Atonement, Mediæval theories of, 159

Augustine, 209

Baptism, 67, 90, 127, 178, 18 1

Bernard of Clairvaux, 195

Biblia Pauperum, 134

Bigg, Charles, 146

Book of Enoch, 32

Browning, 34, 160, 161

Carlyle, 226

Christian Art, 133

Christian Hymnody, 132

Christian Year, 132

Church, Dean, 25, 38, 218

Clement of Alexandria, 201, 205

Clergy and laity, I92

Clutton-Brock, 217

Councils, General, 118

Council of Chalcedon, 122, 208, 212

Council of Nicæa, 122, 199, 205, 212

Credal reform, $23 \mathrm{I}$

Cyprian, 169, 171, 181, 188

Denney, Principal, 122, 128

"Deposit of Faith," 206

Didacbe, I4I

Didron, 134

Dom Romolo Murri, 220
Ecce Homo, 39

Ecclesia, 94, I 66

Emerson, 216

Epictetus, 102

Faut, Dr. S., 229

Fogazzaro, 220

Fowler, W. Warde, 140

Francis of Assisi, 135, I 51

Gardner, Percy, 243

Gibbon, I 55

Gnosticism, I I 3

God and Goodness, 24, 227

God as the Absolute, 87, 1 54, 202

God in Christ, 80, 83, $153,160,206$, 227

God experienced not proved, 25, 213 Gore, Dr. Charles, 182, 183

Gospels in public worship, 106, 128

Gwatkin, Professor, I6I

Hatch, E., 143, I63, 200

Hamilton, Sir W., 120

Harnack, 144, 163, 209, 210

Hunt, Holman, 48

Ignatius, I47, 168

International Christianity, 24I

James, W., 23, 36, 225

Jesus, Life of :

Affinity with joyous side of life, 37

Conscious of a unique vocation, 33 , 41

Unbroken communion with God, 43 


\section{Index}

Companionship with the Twelve, 38 Imperious demands, 34

Claim for personal loyalty, 36,42

Virility, 33

Spiritual struggle, $33,50,5 \mathrm{I}$.

Spiritual loneliness, 42

At Cæsarea Philippi, 46

On the way to the Cross, 47

The Cross and the Coming of the Kingdom with Power, 53

Appearances of the Risen Lord to the Disciples, 62

Jesus as Messiah, 59, 65-67

Jesus as Saviour, 27, 29, 53

Jesus, Personality of :

The miracle of miracles, +5

Dominant factor in Christianity, 216 Justin Martyr, r29, 181, 201

Julian, Emperor, 157

Knox's Liturgy, 176

League of Nations, 24I

Lecky, W. E. H., 2 I 6

Lindsay, Principal, I6I, I63, I8 I

Logos, 87, 1 54, 203

Loisy, Alfred, 124, 155,236

Lord's Supper, 91, I27, I76

Lucian, $\mathbf{r} 62$

Luther, 7I, I60, 195

Marcus Aurelius, 102, 233

Martyrdom of Christians, I 30, 147

Mass, the sacrifice of the, 178

Mazzini, 24 I

Modernism, 220

Monasticism, 147

Montefiore, C. G., 21, 30

"More than others," 17, 22, 75, 122, 145

Mozley, J. B., I17, 124
Mystery religions, $103, \mathrm{II}_{3}$

Mysticism, I 58, 194

Nationalism, 24I

Neo-Platonism, 156

Newman, J. H., 108, I10, 123, 171, 18 3 , 225,227

Nicene Creed, 156, 199, 202, 205, 208, 214, 219, 229, 230

Origen, 36, 152, 153

Paley, 223

Pax Romana, ror

Philo, 87

Pliny's Letter to Trajan, I32, I40, ${ }_{52}$

Polycarp, 130

Pringle-Pattison, 161

Psalms of Solomon, 32

Psichari, Ernest, i6 1

Quakers, I23

Rainy, Principal, I17, 144

Religion and morality, 24, 71, 101, 14?, 221

Renan, 36, 47

Revelation and reason, 2 10

Schleiermacher, 2 I I

Scripture, appeal to, 120

Social reconstruction, 237

Stoicism, 86, 102, 148, 200

Tertullian, 153,164

Tennyson, 217

Thomas à Kempis, 179, 195

Tolstoi, 2 I

Transubstantiation, 177

Tyrrell, Father, 167,220

"Valid Eucharist," I77

Zwingli, 232 


\section{.}




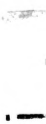



